Prepared for the U.S. Department of Energy

under Contract DE-AC05-76RL01830

\title{
The Geochemistry of Technetium: A Summary of the Behavior of an Artificial Element in the Natural Environment
}
JP Icenhower
WJ Martin
NP Qafoku
JM Zachara

December 2008 


\title{
DISCLAIMER
}

This report was prepared as an account of work sponsored by an agency of the United States Government. Neither the United States Government nor any agency thereof, nor Battelle Memorial Institute, nor any of their employees, makes any warranty, express or implied, or assumes any legal liability or responsibility for the accuracy, completeness, or usefulness of any information, apparatus, product, or process disclosed, or represents that its use would not infringe privately owned rights. Reference herein to any specific commercial product, process, or service by trade name, trademark, manufacturer, or otherwise does not necessarily constitute or imply its endorsement, recommendation, or favoring by the United States Government or any agency thereof, or Battelle Memorial Institute. The views and opinions of authors expressed herein do not necessarily state or reflect those of the United States Government or any agency thereof.

\author{
PACIFIC NORTHWEST NATIONAL LABORATORY \\ operated by \\ BATTELLE \\ for the \\ UNITED STATES DEPARTMENT OF ENERGY \\ under Contract DE-AC05-76RL01830
}

Printed in the United States of America

Available to DOE and DOE contractors from the

Office of Scientific and Technical Information,

P.O. Box 62, Oak Ridge, TN 37831-0062;

ph: (865) 576-8401

fax: $(865) 576-5728$

email: reports@adonis.osti.gov

\author{
Available to the public from the National Technical Information Service, \\ U.S. Department of Commerce, 5285 Port Royal Rd., Springfield, VA 22161 \\ ph: (800) 553-6847 \\ fax: (703) 605-6900 \\ email: orders@ntis.fedworld.gov \\ online ordering: http://www.ntis.gov/ordering.htm
}

This document was printed on recycled paper.

$(9 / 2003)$ 


\title{
The Geochemistry of Technetium: A Summary of the Behavior of an Artificial Element in the Natural Environment
}

\author{
JP Icenhower WJ Martin \\ NP Qafoku JM Zachara
}

December 2008

Prepared for

the U.S. Department of Energy

under Contract DE-AC05-76RL01830

Pacific Northwest National Laboratory

Richland, Washington 99352 



\section{Summary}

Interest in the chemistry of technetium has only increased since its discovery in 1937, mainly because of the large and growing inventory of ${ }^{99} \mathrm{Tc}$ generated during fission of ${ }^{235} \mathrm{U}$, its environmental mobility in oxidizing conditions, and its potential radiotoxicity. For every ton of enriched uranium fuel ( 3 percent

${ }^{235} \mathrm{U}$ ) that is consumed at a typical burn-up rate, nearly $1 \mathrm{~kg}$ of ${ }^{99} \mathrm{Tc}$ is generated. Thus, the mass of ${ }^{99} \mathrm{Tc}$ produced since 1993 has nearly quadrupled, and will likely to continue to increase if more emphasis is placed on nuclear power to slow the accumulation of atmospheric greenhouse gases. In order to gain a comprehensive understanding of the interaction of ${ }^{99} \mathrm{Tc}$ and the natural environment, we review the sources of ${ }^{99} \mathrm{Tc}$ in the nuclear fuel cycle, its chemical properties, radiochemistry, and biogeochemical behavior. We include an evaluation of the use of rhenium as a chemical analog of technetium, as well as a summary of the redox potential, thermodynamics, sorption, colloidal behavior, and interaction of humic substances with technetium, and the potential for reoxidation and remobilization of $\mathrm{Tc}(\mathrm{IV})$. What emerges is a more complicated picture of technetium behavior than that of an easily tractable transition of $\mathrm{Tc}(\mathrm{VII})$ to $\mathrm{Tc}(\mathrm{IV})$ with consequent immobilization. Reducing conditions ( +200 to $+100 \mathrm{mV} E_{\mathrm{h}}$ ) are generally thought necessary to cause reduction of Tc(VII) to Tc(IV), but far more important are the presence of reducing agents, such as Fe(II) sorbed onto mineral grains. Catalysis of Tc(VII) by surfacemediated Fe(II) will bring the mobile Tc(VII) species to a lower oxidation state and will form the relatively insoluble $\mathrm{Tc}(\mathrm{IV}) \mathrm{O}_{2} \cdot n \mathrm{H}_{2} \mathrm{O}$, but even as a solid, equilibrium concentrations of aqueous technetium are nearly a factor of 20 times above the U. S. Environmental Protection Agency set drinking water standards. However, sequestration of Tc(IV) into Fe(III)-bearing phases, such as goethite or other hydrous oxyhydroxides of iron, may ameliorate concerns over the mobility of technetium. Further, the outcome of many studies on terrestrial and marine sediments that are oxidizing overall indicate that technetium is relatively immobile, because of the formation of oxygen-depleted microenvironments that develop in response to bacteriological activities. The rate of remobilization of technetium from these microenvironments is just beginning to be assessed, but with no firm consensus. Reassessment of the simple models in which technetium is mobilized and immobilized is therefore urged. 



\section{Acknowledgments}

A number of individuals contributed comments and suggestions to this work, and they are gratefully acknowledged. These include: Matt Marshall, Dawn Wellman, Chris Brown, Ken Krupka, Kate Draper, and Jeff Serne. Any errors, however, are solely the responsibility of the primary author. This work was supported by the U.S. Department of Energy, Environmental Management Office of Engineering and Technology, and the Office of Science. 



\section{Acronyms and Abbreviations}

$\begin{array}{ll}\text { Bq } & \text { bequerel } \\ \text { Ci } & \text { curie } \\ \text { DMRB } & \text { dissimilatory metal reducing bacteria } \\ \text { DWS } & \text { drinking water standard } \\ \text { eV } & \text { electron volt } \\ \text { EDTA } & \text { ethylene diamine tetraacetic acid } \\ \text { EMF } & \text { electromotive force } \\ \text { EPA } & \text { U.S. Environmental Protection Agency } \\ \text { EXAFS } & \text { extended x-ray absorption fine structure } \\ \text { Ga } & \text { giga annum (1 billion years) } \\ \text { HREE } & \text { heavy rare earth elements } \\ K_{\mathrm{D}} & \text { Partition coefficient-mL/g } \\ \text { MT } & \text { metric tonnes } \\ \text { MWd/MT } & \text { megawatt day per metric tonne } \\ \text { OMCs } & \text { outer membrane } c \text {-type cytochromes } \\ \text { RRY } & \text { reference reactor year } \\ \text { SNF } & \text { spent nuclear fuel } \\ \text { SSE } & \text { selective solution extractions } \\ \text { Sv } & \text { sievert } \\ \text { TBP } & \text { tributyl phosphate } \\ \text { V } & \text { volt } \\ \text { XANES } & \text { x-ray absorption near-edge spectroscopy } \\ \text { XAS } & \text { x-ray absorption spectroscopy } \\ & \end{array}$





\section{Contents}

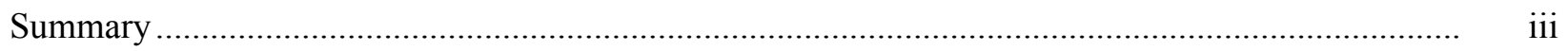

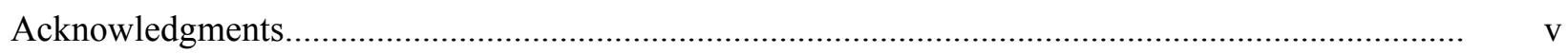

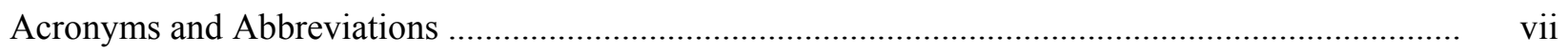

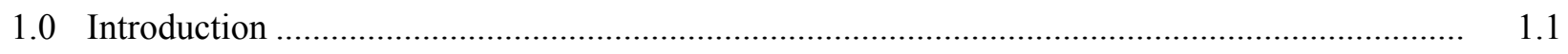

2.0 Sources of Technetium in the Environment ..................................................................... 2.1

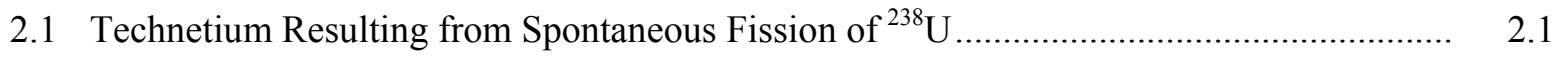

2.2 Technetium from Natural Reactors ....................................................................... 2.1

2.3 Technetium in Spent Fuel Rods .............................................................................. 2.2

2.4 Technetium in Nuclear Waste Awaiting Final Disposition.............................................. 2.3

2.5 Technetium in Glass Waste Forms.............................................................................. 2.3

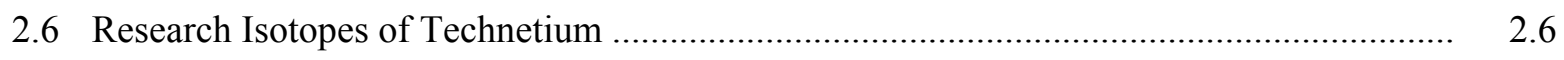

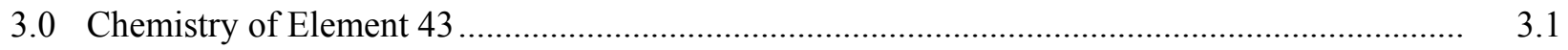

4.0 Use of Rhenium as a Geochemical Analog of Technetium .................................................... 4.1

5.0 Radiochemistry — the Isotopes and Isomers of Technetium ................................................

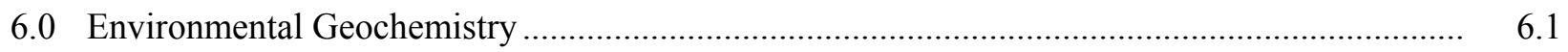

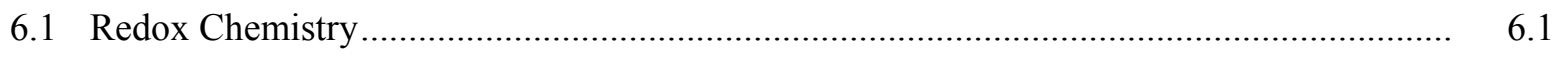

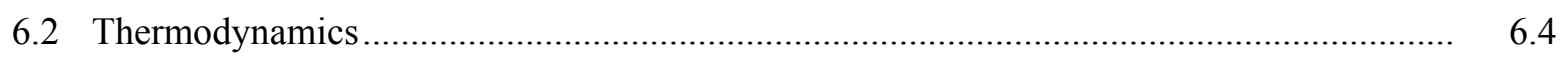

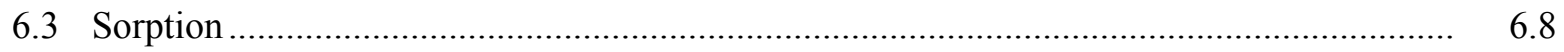

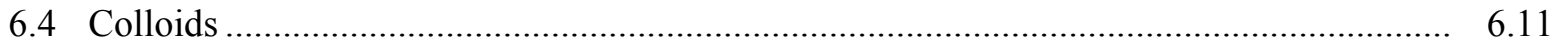

6.5 Interaction with Humic Substances .................................................................... 6.12

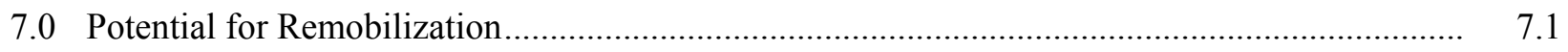

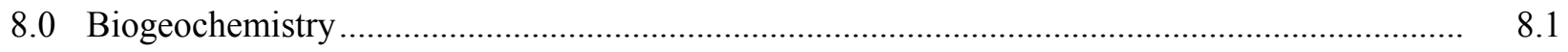

8.1 Microorganisms in the Environment and Bioreduction ............................................... 8.1

8.2 Reduction by Direct Enzymatic Activity ….................................................................. 8.2

8.3 Reduction of Tc(VII) Via Biogenic Iron (II) Catalysis ................................................. 8.4

8.4 Reduction Coupled with Sulfur Reduction .................................................................. 8.5

8.5 Reduction Coupled with De-nitrification .............................................................. 8.6

9.0 Discussion and Recommendations for Future Studies ....................................................... 9.1

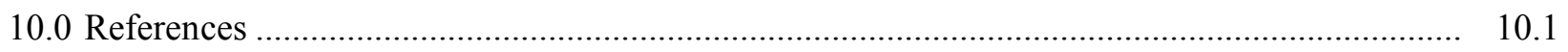




\section{Figures}

3.1 Block Diagram Indicating the Relative Positions of Technetium and Congeners in the Periodic Table

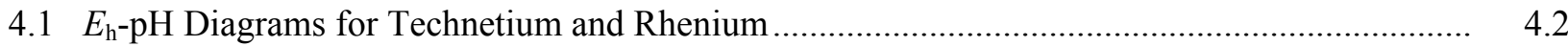

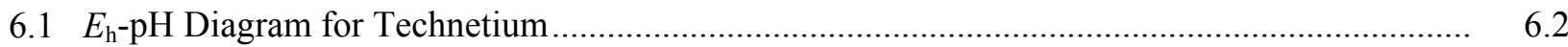

8.1 Structural Diagrams of the Active Sites of [FeNi] and [FeFe] Hydrogenase Proteins ................ 8.2

8.2 A Cartoon Cross-Section Showing the Inner and Outer Membranes Separated by the Periplasmic Space in a Gram-Negative Bacterial Cell Wall

\section{Tables}

3.1 Chemical and Electronic Properties of Technetium and Similar Elements

3.2 List of Cationic Radii of the VI, VII, and VIIIB Block Elements in Picometers

5.1 A List of the Principle Technetium Isotopes and Isomers, Their Respective Half-Lives, Decay Mechanisms, Energies, and Decay Products

5.2 A List of the Principle Technetium Isotopes Produced by Fission of ${ }^{235} \mathrm{U}$, Their Percent Yields, and Half-Lives.

6.1 Summary of Aeration Status of Soils and Their Correspondence With Biogeochemical Zones.

6.2 Values of Standard Enthalpy and Free Energy of Formation and Entropy of the Principle Solids of $\mathrm{Tc}, \mathrm{Re}$, and $\mathrm{Ru}$

6.3 Free Energies of Formation of Aqueous Technetium Species and the Perrhenate Anion

6.4 Standard Enthalpies and Free Energies of Formation of Cr, Mo, W, Mn, Tc, Re, Ru, and Os Compounds 


\subsection{Introduction}

The discovery of a new element in by Perrier and Segrè in 1937 (1937a, 1937b) ushered in a new era in chemistry. The new element, which they named technetium, derived from the Greek word "technetos" ( $\tau \varepsilon \chi \eta \vee \varepsilon \tau O \sigma)$ or artificial, was produced synthetically by deuteron activation of a piece of molybdenum metal that had undergone bombardment in the cyclotron in Berkeley. Technetium turned out to be the lightest element $(Z=99)$ comprising only unstable isotopes, none of which are long-lived enough to be present from the formation of the Earth, and would merely be a chemical curiosity were it not for its environmental impact. Fission of enriched uranium (fuel rods of uranium dioxide that contain approximately 3 percent ${ }^{235} \mathrm{U}$ ) produces a number of fission products, including several technetium isotopes. Fissionogenesis favors the heavier isotopes of technetium (Kotegov et al. 1968) with ${ }^{99} \mathrm{Tc}$ having the highest yield (6.06 percent). The other high-yield isotopes of technetium have short half-lives (18 min. to less than $60 \mathrm{~s}$ ), but ${ }^{99} \mathrm{Tc}$ has a half-life of $2.13 \times 10^{5}$ years, making it the most important technetium isotope in the nuclear fuel cycle (Luykx 1984).

Although most of the ${ }^{99} \mathrm{Tc}$ is sequestered in minute dissolution-resistant metal aggregates in spent fuel rods (Buck et al. 2004), reprocessing the fuel rods results in liberation of technetium, which is carried along in solution with other radioisotopes in the reclamation effort (Colton 1965; Till 1984). When exposed to the atmosphere or any moderately oxidizing environment, technetium is manifested as the pertechnetate anion $\left({ }^{99} \mathrm{TcO}_{4}{ }^{-}\right)$, which is highly soluble in aqueous solution, meaning that this anion can be found in solution well above the drinking water standard of $900 \mathrm{pCi} / \mathrm{L}$ (EPA 2002). In a number of settings where production of atomic weapons or waste from nuclear energy is stored or processed, the accidental or approved release of ${ }^{99} \mathrm{TcO}_{4}{ }^{-}$to the environment has led to widespread contamination of seawater (Brown et al. 1999; Dahlgaard et al. 2004; Keith-Roach and Roos 2004; Lindahl et al. 2003; McCubbin et al. 2006; Morris et al. 2000), rivers (Aarkrog et al. 1997), estuaries (Burke et al. 2006; Burke et al. 2005), groundwater (Brown et al. 2006; Brown et al. 2007; Serne et al. 2004; Serne 2001) and the sediments with which they are associated. Because typical sediments in temperate climates possess an overall negative charge at circum-neutral $\mathrm{pH}$ conditions, the pertechnetate anion is electrostatically repelled and is poorly attenuated (Kaplan and Serne 1998; Sheppard and Sheppard 1984; Wildung et al. 1984; Wildung et al. 1974). For these reasons, ${ }^{99} \mathrm{Tc}$ has been used as an excellent tracer of oceanic currents (Aarkrog et al. 1987) and is transported in the subsurface at nearly the same velocity as groundwater (Rudin et al. 1992).

When released to the environment, a number of plants and animals take up ${ }^{99} \mathrm{Tc}$ to an appreciable extent (Bennett and Willey 2003; Bonotto et al. 1985; Brown et al. 1999; Hattink et al. 2000; Hattink and Wolterbeek 2001; Oliver et al. 2006; Thorne 2003) and the biomagnifications of ${ }^{99} \mathrm{Tc}$ in the food chain is an obvious concern. What prevents this radioisotope from being a major pollution threat is that the distribution of ${ }^{99} \mathrm{Tc}$ in the environment, although widespread resulting from atomic weapons testing, is typically at very low concentrations (less than $10^{-10} \mathrm{~g} \mathrm{Tc} / \mathrm{g}$ sediment; Morris et al. 2000). At present, the concentrations of ${ }^{99} \mathrm{Tc}$, even when biomagnified through the food chain, are such that uptake to humans through consuming contaminated food is not an obvious health risk. For example, Smith et al. (2001) showed that even heavy consumption of marine animals from the Irish sea contributes only 0.24 microSievert $^{1}(\mu \mathrm{Sv})$ per year, while average background radiation accounts for $1000 \mu \mathrm{Sv}$ per annum. In addition, the biological half-life of consumed ${ }^{99} \mathrm{Tc}$ is typically short (approximately 60 hours for humans)

\footnotetext{
${ }^{1}$ One Sievert (Sv) is equivalent to deposition of $1 \mathrm{~J} / \mathrm{kg}$ of energy, or $100 \mathrm{rem}$.
} 
and, coupled with the low-energy beta decay $\left(E_{\max }=0.292 \mathrm{MeV}\right)$, it is unlikely to pose a significant radiological threat under most conceivable exposure scenarios (EPA 2002). On the other hand, aspiration of ${ }^{99} \mathrm{Tc}$ and resultant accumulation in lung tissue, which has a much longer biological excretion half-life, does present a significant risk. For this exposure pathway, inhalation of dust or vapor tainted with ${ }^{99} \mathrm{Tc}$ could lead to lung cancer and related maladies. Therefore, because of its high mobility, high fission yield in nuclear energy production, long half-life, and moderate radiotoxicity, ${ }^{99} \mathrm{Tc}$ is an element of intense concern for the environment.

Estimates of the quantity of ${ }^{99} \mathrm{Tc}$ that has been produced vary somewhat, but a recent survey indicates that atmospheric nuclear testing has resulted in approximately 100 to $140 \times 10^{12} \mathrm{~Bq}^{1}$ of ${ }^{99} \mathrm{Tc}$ released, much of which has been deposited and become incorporated in sediments. An additional approximately $1 \times 10^{15} \mathrm{~Bq}(1 \mathrm{PBq})$ of ${ }^{99} \mathrm{Tc}$ has been released through reprocessing of spent fuel (Schulte and Scoppa 1987). However, this amount is small in comparison to the stock of ${ }^{99} \mathrm{Tc}$ that is awaiting final disposition. For example, at the Hanford Site, Washington State, nearly $1990 \mathrm{~kg}$ of ${ }^{99} \mathrm{Tc}$ (or $1.25 \mathrm{PBq}$ ) was produced between 1943 and 1987 (Darab and Smith 1996). A fraction of this technetium inventory has been shipped offsite, co-extracted with uranium oxide product, or released to the environment. The balance, estimated as $1310 \pm 220 \mathrm{~kg}$ or $22,720 \pm 3820 \mathrm{Ci}$, is stored in single- and double-shell tanks. Some of the single-shell tanks are suspected or known to have leaked, and concern persists that technetium may enter the groundwater and eventually reach the Columbia River.

In addition to that which has already been produced, technetium continues to be accumulated in large amounts because of active nuclear power generation. According to Kloosterman (2008), $21 \mathrm{~kg}$ of ${ }^{99} \mathrm{Tc}$ $(13.2 \mathrm{TBq})$ are produced annually in a large $1 \mathrm{GWe}$ reactor. His estimated inventory of ${ }^{99} \mathrm{Tc}$ produced in 2007 is 15.1 metric tonnes (MT). In 1994, there were approximately $78 \mathrm{MT}$ of ${ }^{99} \mathrm{Tc}$. Accordingly, if the 2007 production value is roughly average, then there are approximately $290 \mathrm{MT}(182.6 \mathrm{PBq})$ of ${ }^{99} \mathrm{Tc}$ today. In other words, the inventory of ${ }^{99} \mathrm{Tc}$ has nearly quadrupled between 1994 and 2008 so the specter of technetium pollution will continue to be a source of concern well into the future.

The available data indicate, therefore, that ${ }^{99} \mathrm{Tc}$ contamination is widespread and, in some case, highly concentrated, and is environmentally mobile. Another body of data, however, indicates that the mobility of technetium in the environment may be substantially less than in the scenario sketched out above. In numerous settings, soil scientists, environmental chemists, agronomists and microbiologists have reported substantial retention of technetium in sediments in oxidizing environments that would otherwise be extremely mobile. For example, soil scientists have shown repeatedly, both through laboratory and field tests that the biological uptake of technetium into plants progressively decreases with time (Echevarria et al. 1997; Tagami and Uchida 1997; Tagami and Uchida 1999; Vandecasteele et al. 1989; Vandecasteele et al. 1985). The bioavailability of technetium appears to be related to its oxidation state; as the pertechnetate anion, technetium can be transported from soil to components of the plant, whereas the reduced form of technetium, Tc(IV), is immobile (Yanagisawa and Muramatsu 1995; Yanagisawa et al. 1999). Thus, technetium appears to be immobile, even for settings in which the bulk $\mathrm{pH}-E_{\mathrm{h}}$ conditions are consistent with oxidizing and, therefore, technetium-mobile, conditions. Other investigators have noted the relative immobility, or attenuated mobility, of technetium in vadose zone pore solutions. For example, Bondietti and Francis (1979) first called attention to the possibility that ${ }^{99}$ Tc migration was slower than thought, mainly because there is evidence for a heterogeneous subsurface environment that

\footnotetext{
${ }^{1}$ One Becquerel $(\mathrm{Bq})=1$ disintegration $/$ second $=2.7 \times 10^{-11} \mathrm{Ci} . \mathrm{TBq}=$ terabecquerel $\left(10^{12}\right) ; \mathrm{PBq}=$ petabecquerel $\left(10^{15}\right)$.
} 
may impose locally reducing conditions, causing a retardation of technetium mobility. In a similar vein $\mathrm{Hu}$ and Smith (2004) and Hu et al. (2008) reported that technetium released during atomic weapons testing behaved less conservatively than expected. In these cases, as well as for those involving soil studies, the importance of microenvironments, in which the local redox state is much different than that surrounding it, is clearly an important consideration that needs to be addressed before overly-conservative models of technetium mobility in the environment are fashioned.

Accordingly, we will discuss the chemistry of technetium in the environment in terms of the controls on its mobility, such as oxidation/reduction potential, solubility, colloid formation, affinity for natural organic matter, the potential of incorporation into dissolution-resistant phases, and biogeochemistry. We preface this review by noting that, in the past, a number of excellent reviews have already been published. For example, Colton (1965) and Peacock (1966) published monographs on technetium, and these were followed by an excellent summary of technetium chemistry in the form of a book chapter in 1968 by Kotegov et al. In 1986, the Commission of the European Communities, Radiation Protection Programme, published a collection of papers on technetium behavior from a special seminar conducted in Cadarache, France (Desmet and Myttenaere 1986). In 1999, Rard and co-investigators published the outstanding review of the chemical thermodynamics of technetium (Rard et al. 1999). A year later, Schwochau (2000) completed a book on the radiopharmaceutical aspects of technetium, which is a response to the explosive growth of using ${ }^{99 \mathrm{~m}} \mathrm{Tc}$ for cellular imaging in the human body. However, the discussion of technetium is not limited solely to books; an entire issue of Health Physics was dedicated to the behavior of technetium in the environment (Wildung 1989). It is not our intention to merely replicate the information contained in these reviews, but to summarize the salient data, place the data into one easily accessible source, and to update the state of knowledge of technetium behavior in the environment. 



\subsection{Sources of Technetium in the Environment}

\subsection{Technetium Resulting from Spontaneous Fission of ${ }^{238} \mathrm{U}$}

Nearly all of the technetium in existence today is the result of either neutron or deuteron activation of molybdenum isotopes or from fission of ${ }^{235} \mathrm{U}$ and ${ }^{239} \mathrm{Pu}$. Only very small concentrations of "natural" technetium exist in nature and, because of relatively short half-lives compared to the age of the Earth, no primordial technetium is present today. However, small quantities of technetium can be produced by spontaneous fission processes in ${ }^{238} \mathrm{U}$. Theoretically, the amount of ${ }^{99} \mathrm{Tc}$ that could be produced in secular equilibrium by natural fission events of ${ }^{238} \mathrm{U}$ is given by:

$$
Y_{99} \mathrm{~N}^{238} \lambda_{238 \mathrm{f}}=\mathrm{N}^{99} \lambda_{99}
$$

Where $\mathrm{N}^{238}$ and $\mathrm{N}^{99}$ represent the number of ${ }^{238} \mathrm{U}$ and ${ }^{99} \mathrm{Tc}$ atoms, respectively; $\lambda_{238 \mathrm{f}}$ and $\lambda_{99}$ are, respectively, the spontaneous fission decay constants of ${ }^{238} \mathrm{U}$ and ${ }^{99} \mathrm{Tc}$, and $Y_{99}$ is the fission yield of ${ }^{99} \mathrm{Tc}$, which is approximately 6.03 percent. Therefore, in one $\mathrm{kg}$ of pitchblende ore, there should be approximately $2.5 \times 10^{-10} \mathrm{~g}$ of Tc (or 10.5 disintegrations per minute). With this as a guide, Kenna and Kuroda (1961) were able to demonstrate the first natural occurrence of technetium in a terrestrial sample. It is interesting to note that this report came nearly 10 years after the technetium spectra were observed in relatively young stars undergoing the S-process outside of our solar system (Merrill 1952).

\subsection{Technetium from Natural Reactors}

Present day uranium is made up of only approximately 0.72 percent ${ }^{235} \mathrm{U}$, but in the past, the proportion of ${ }^{235} U$ to ${ }^{238} U$ was higher, owing to the relatively shorter half-life of ${ }^{235} U$ compared to ${ }^{238} U$. If the mass, the amount of water present, and certain geometric aspects of a uranium deposit are suitable, if the ratio of ${ }^{235} \mathrm{U}$ to ${ }^{238} \mathrm{U}$ is high, if there are neutron reflectors, like quartz, that bound the deposit, and if the concentrations of neutron absorbers (e.g., boron, lithium, manganese, vanadium, and heavy rare earth elements (HREE) are low, then a nuclear chain reaction can be induced.

With the restrictions that these conditions impose, it is perhaps surprising that any "natural reactors" could have operated. Yet, there has been several localities in which "natural reactors" were known to exist, the most studied of which were the deposits at Oklo, in the central West African country of Gabon (e.g., Brookins 1990; Curtis 1986; Curtis et al. 1989; Gauthier-Lafaye et al. 1996; Janeczek 1999). In all, 15 natural reactors are known to have operated for various durations in the nearly 2 billion-year-old $(2.0 \mathrm{Ga})$ uranium deposits. In total, nearly $730 \mathrm{~kg}$ of ${ }^{99} \mathrm{Tc}$ were thought to be produced in the reactors, and today that technetium is represented by ${ }^{99} \mathrm{Ru}$, the stable daughter of ${ }^{99} \mathrm{Tc}$. In the Oklo deposits, metallic phases containing ruthenium, rhodium, tellurium, arsenic, sulfur, lead, and palladium are observed and bear resemblance to the metallic "epsilon" phases (ruthenium, rhodium, palladium, molybdenum, and technetium) in spent nuclear fuel (see below). These observations are consistent with a lack of large-scale migration of ${ }^{99} \mathrm{Tc}$ after fission genesis, because most of the ${ }^{99} \mathrm{Ru}$-bearing "metal aggregates" are within 10 meters of the reactor "core" (Gancarz et al. 1980; Hidaka et al. 1999; Hidaka et al. 1993; Janeczek 1999). The apparent lack of mobility of ${ }^{99} \mathrm{Tc}$ in this setting has led some investigators to conclude that loss of technetium from spent fuel rods disposed in geologic formations will be unimportant, since so little mobility was observed in a deposit of approximately $2.0 \mathrm{Ga}$. This may be somewhat misleading, however, because the Oklo deposits are bounded by organic-rich sediments that 
not only impose a reducing oxidation state on the lithologies, but also provides sorption sites for uranium and other radionuclide elements (Janeczek 1999). The potential for organic matter to immobilize technetium will be discussed more fully below.

\subsection{Technetium in Spent Fuel Rods}

The greatest source of ${ }^{99} \mathrm{Tc}$ is its artificial production by neutron-induced fission and because the fission yield of ${ }^{99} \mathrm{Tc}$ is 6.06 percent, one ton of ${ }^{235} \mathrm{U}$-enriched fuel ( 3 percent enrichment) will produce approximately $1 \mathrm{~kg}$ of ${ }^{99} \mathrm{Tc}$ at a typical burn up rate (Chen et al. 2000). Similar estimates were provided by Till (1984). Till estimated the amount ${ }^{99} \mathrm{Tc}$ generation on one reference reactor year (RRY), which is based on irradiation of 40 metric tons of enriched $\mathrm{UO}_{2}\left(3.2 \mathrm{wt} \%{ }^{235} \mathrm{U}\right)$. When "burned" at a rate of 33,000 MWd/MT, (megawatt day per metric tonne) spent fuel still contains $0.84 \mathrm{wt} \%{ }^{235} \mathrm{U}$. Reprocessing the spent fuel and re-irradiation will produce more ${ }^{99} \mathrm{Tc}$ as well as other isotopes of technetium whose half-lives are short. Other isotopes that are fissile will also be produced and some of these will contribute to the production of ${ }^{99} \mathrm{Tc}$. For example, ${ }^{233} \mathrm{U}$ fission produces 4.8 percent and ${ }^{239} \mathrm{Pu} 5.9$ percent ${ }^{99} \mathrm{Tc}$, and fast neutron fission will yield 5.9 percent ${ }^{99} \mathrm{Tc}$ from ${ }^{239} \mathrm{Pu}, 6.3$ percent from ${ }^{238} \mathrm{U}$, and 2.7 percent from ${ }^{232} \mathrm{Th}$. When normalized on the RRY basis, the amount of ${ }^{99} \mathrm{Tc}$ produced is between 11.9 and 14.5 Ci/MT, depending on the type of reactor. Reprocessing of spent uranium fuel rods to recover ${ }^{235} \mathrm{U}$, ${ }^{239} \mathrm{Pu}$, and other fissile elements is the chief means by which technetium becomes part of the waste stream.

Without human intervention, technetium in spent nuclear fuel (SNF) is immobilized in metallic phases that form in void spaces within fuel rods (Kleykamp 1985). These small, metallic aggregates, known as "epsilon phases" (or $\varepsilon$-phases; also known as "white phases") contain ruthenium, rhodium, platinum, molybdenum, and technetium. Therefore, in order to mobilize technetium, a great deal of uranium dioxide would have to be dissolved to expose the $\varepsilon$-phases to aqueous solution (Buck et al. 2004). Although there are no specific data on the rate of aqueous dissolution of $\varepsilon$-phases, dissolution experiments on radionuclide-bearing metallic waste forms indicate that release of technetium is slow (Johnson et al. 2002) and, therefore, technetium in this manifestation constitutes a minor source. On the other hand, use of chelating agents to separate metals during reprocessing of SNF or to isolate plutonium produced in irradiated uranium targets for atomic weapons production typically results in soluble forms of technetium (Colton 1965; Lieser and Bauscher 1987). For example, technetium is solubilized during the plutonium and uranium recovery and extraction (PUREX) process, one of the main procedures for reclaiming uranium and plutonium. Spent fuel is dissolved in concentrated nitric acid and then tributyl phosphate (TBP) is added to complex uranium and plutonium. Some technetium follows uranyl nitrate as $\mathrm{HTcO}_{4}$ through the extraction process and is converted to $\mathrm{Tc}_{2} \mathrm{O}_{7}$ during denitration and calcining. About 20 percent of technetium remains in the separated uranium fraction and approximately 80 percent follows either fission products waste stream or the plutonium fraction. For every $34 \mathrm{MT}$ of uranium returned for re-enrichment, there will be $100 \mathrm{Ci}$ ( approximately $6 \mathrm{~kg}$ or $176 \mathrm{ppm}$ technetium). Regulations specify that only $4 \mathrm{ppm}{ }^{99} \mathrm{Tc}$ be present in reprocessed fuel $\left(2.3 \mathrm{Ci}\right.$ or $0.14 \mathrm{~kg}$ ). Thus, the rest of the ${ }^{99} \mathrm{Tc}$ (or approximately $508 \mathrm{Ci} / \mathrm{RRY}$ ) must go to the high-level waste stream (Till 1984).

Dissolution of uranium and fluorination to produce $\mathrm{U}(\mathrm{VI}) \mathrm{F}_{6}$ also produces fluoride complexes of technetium, such as $\mathrm{Tc}(\mathrm{VI}) \mathrm{F}_{6}$ and $\mathrm{Tc}(\mathrm{VII}) \mathrm{O}_{3} \mathrm{~F}$, with the former more abundant than the latter. Although these are potentially fugitive species because of their volatility, most of the contamination caused by technetium fluorides is because of accidental release into water, where it hydrolyzes and disproportionates 
into Tc(VII) and Tc(IV). In localities where gaseous diffusion operations occurred, such as Paducah, Kentucky, and Oak Ridge, Tennessee, nearly 97.5 percent ${ }^{99} \mathrm{Tc}$ is discharged to the environment through aqueous solution and only 2.5 percent by gaseous pathways (Till 1984).

\subsection{Technetium in Nuclear Waste Awaiting Final Disposition}

In some cases, small quantities of technetium are disposed directly to seawater (such as in Sellafield, United Kingdom, or Le Hague, France), or to engineered storage ponds in river systems (in Mayak, Russia). However, by far, the majority of technetium is stored along with other waste in storage tanks or other retaining culverts excavated in surface sediments, as illustrated in the example of the Hanford Site in Washington State. At Hanford, atomic weapons production necessitated the construction of 177 singleand double-shell underground storage tanks to accommodate the large amount of waste. Clusters of tanks, known as "tank farms", were built in scattered locations and the earliest ones (from the 1950s) were of the single-shell variety. Unfortunately, nearly one-third of the tanks has leaked or is suspected to have leaked based upon anecdotal and "hard" evidence (Gee et al. 2007). So far, leaks have occurred exclusively in the single-shell farms or from ruptures along associated underground transfer pipes or diversion boxes. In addition, there have been cases of inadvertent overfilling of tanks with consequent loss of waste to surrounding soils. As much as $460 \mathrm{Ci}$ of ${ }^{99} \mathrm{Tc}$ have been released to the underlying sediments resulting from these mishaps with concentrations of greater than $1.5 \times 10^{-5} \mathrm{~mole} / \mathrm{L}$ technetium detected in some areas. In addition to this, a series of cribs, trenches, and holding ponds were carved out of the sediments near plutonium production plants and these were filled with aqueous solutions containing technetium and other radionuclide elements. As much as $930 \mathrm{Ci}$ of technetium were intentionally discharged to the vadose zone where, at the time, it was presumed that radionuclide elements would not pose a migration risk. However, because the vadose zone at Hanford is oxidizing, the presumed technetium species is the pertechnetate anion, $\mathrm{TcO}_{4}{ }^{-}$, which exhibits high mobility in such settings. Accordingly, there is ample reason to think that technetium-laced waste will rapidly migrate from the vadose zone to the underlying aquifer. Some estimates set a travel time of only 40 to 50 years in the 200 East and 125 to 135 years in the 200 West areas before technetium reaches the Hanford aquifer (Hartman et al. 2004). Already, there is some indication that technetium has already reached groundwater beneath Waste Management Area T. Because the groundwater at the Hanford Site discharges into the nearby Columbia River, a major waterway in the Pacific Northwest, a great deal of environmental harm could result unless intervening remediation strategies are employed.

Another source of technetium pollution occurs through the mishandling of raffinates, which are solutions that were used to clean and decontaminate tools and facilities in uranium-enrichment plants. For example, concentrations as high as $2.2 \times 10^{8} \mathrm{pCi} / \mathrm{L}$ have been recorded in some raffinates. Mishandling of raffinates may result in pollution of groundwater near such facilities, as demonstrated by high technetium concentrations of 1000 to 3000 pCi/L in Paducah, Kentucky, and Portsmouth, Ohio, gaseous diffusion plants (Liang et al. 1996).

\subsection{Technetium in Glass Waste Forms}

In the future, a major source of potential technetium release to the environment will be from reaction of low-activity waste glass with groundwater. In the previous section we alluded to the high- and low-activity waste streams resulting from processing of irradiated uranium produced for the purpose of atomic weapons manufacturing. In the case of the Hanford Site in Washington State, nearly 90 percent 
by volume of waste will be made up by the low-activity fraction, which contains approximately $2.4 \times 10^{6}$ curies of radioactivity, much of this represented by technetium. Current plans call for removing waste that is stored in 177 underground single- and double-shell tanks and converting the low-activity fraction into glass. Approximately $160000 \mathrm{~m}^{3}$ of low-activity glass will be encased in metal canisters and will be buried in shallow trenches on site (McGrail et al. 2001). As water percolates through the disposal system over time a small percentage of the canisters will be breached and the glass will react with a prospect that technetium will be released to the subsurface environment. Currently, the data are sparse concerning the mechanism by which technetium would be released from glass.

Part of the problem in understanding technetium release from glass arises because of uncertainties in the speciation of technetium in the glassy environment. Early studies yield apparently contradictory and anti-intuitive data. For example, Freude et al. (in Darab and Smith 1996) conducted square-wave voltammetry (SWV) measurements on technetium-bearing borosilicate glass in order to determine the redox state of technetium in melts produced under reducing or oxidizing conditions. They acquired a redox potential of the melt of $-250 \mathrm{mV}$, consistent with $\mathrm{Tc}(\mathrm{IV})$ in the glass, for melts generated in a reducing atmosphere. For glass melted under oxidizing conditions, they found a redox potential of $50 \mathrm{mV}$. They assigned this redox potential to the presence of Tc(VII) in glass. In contrast, Antonini et al. (1985) found that glasses formed during either reducing or oxidizing conditions contained predominately Tc(IV), as revealed by x-ray absorption near-edge spectroscopy (XANES) and extended x-ray absorption fine structure (EXAFS) methods. These results are surprising, because it is assumed that under oxidizing conditions, technetium should be in the +7 state. Further mystery surrounds the results of the study on glass generated under reducing conditions; in addition to the presence of Tc(IV), the authors also reported the presence of $\operatorname{Tc}(0)$ (i.e., metallic technetium). Darab and Smith (1996) suggested that one potential reason for this apparent contradiction is that the oxidation state of technetium depends strongly on the starting materials used to make the glass.

For example, Darab and Smith (1996) showed that if starting materials contained a modicum of organic materials, like what is expected in real tank waste, then reaction between molten nitrate salts and organics such as ethylene diamine tetraacetic acid (EDTA) yields $\mathrm{CO}_{2}, \mathrm{NO}_{\mathrm{x}}, \mathrm{CH}_{4}$ and even $\mathrm{H}_{2}$ gases that lower the partial pressure of $\mathrm{O}_{2}$ in the melter, resulting in a lower oxidation state of the glass. The theme of the importance of starting materials was amplified by a study of Lukens et al. (2004), who showed that by including a small amount of reducing components the resulting glass contained predominately Tc(IV) in octahedral coordination [i.e., $\mathrm{Tc}(\mathrm{IV}) \mathrm{O}_{6}$ ] evenly disseminated throughout the glass. Increasing the amount of reducing components or using $\mathrm{TcO}_{2} \cdot 2 \mathrm{H}_{2} \mathrm{O}$ in the starting material resulted in solid $\mathrm{TcO}_{2}$ inclusions within the glass. However, if an oxidized form of technetium was used in the starting materials (e.g., $\mathrm{NaTcO}_{4(\mathrm{~s})}$ ) in the absence of reducing components, then the predominate form of technetium in the glass was Tc(VII).

Both the studies of Darab and Smith (1996) and Lukens et al. (2004) were also interested in the volatility of technetium as the starting materials were heated and melted. This is a concern, because a number of $\mathrm{Tc}(\mathrm{VII})$ compounds boil at relatively low temperatures: $\mathrm{TcO}_{3} \mathrm{Cl}$ and $\mathrm{TcO}_{3} \mathrm{~F}$ boil at temperatures less than $100^{\circ} \mathrm{C}$, and $\mathrm{Tc}_{2} \mathrm{O}_{7}$ boils at $350^{\circ} \mathrm{C}$. Therefore, if these compounds are present in the waste and are sent to the melter, there is a good chance that much of the technetium will be lost to the gaseous phase during the heating process. Darab and Smith (1996) showed, for example, that glass formation under reducing conditions resulted in 75 percent of the technetium budget retained in the glass product. In contrast, only 45 percent of the technetium was withheld in the glass during melting under oxidizing conditions. 
Other factors affect the volatility of technetium as well. If the starting form of technetium is $\mathrm{NH}_{4} \mathrm{TcO}_{4}$, then this material will go through a phase transition to form $\mathrm{Tc}_{2} \mathrm{O}_{7}$, which, as mentioned earlier, volatilizes at low temperatures $\left(350^{\circ} \mathrm{C}\right)$. However, it is likely that other salts of pertechnetate will form the bulk of technetium-bearing solids in the waste feed. Of these, the likeliest candidates include $\mathrm{KTcO}_{4}, \mathrm{NaTcO}_{4}$, and $\mathrm{CsTcO}_{4}$, in decreasing likelihood of occurrence. Upon heating, the alkali metal salts will not volatilize until they melt and reach their boiling points $\left(T_{\mathrm{b}}\right)$, which are much higher (e.g., $T_{\mathrm{b}}=1095^{\circ} \mathrm{C}$ for $\left.\mathrm{KTcO}_{4}\right)$ than that of $\mathrm{Tc}_{2} \mathrm{O}_{7}\left(T_{\mathrm{b}}=350^{\circ} \mathrm{C}\right)$. In addition, the temperature at which the waste feed materials densify prior to melting will also exert a strong effect on technetium volatility. As pointed out by Darab and Smith (1996), the higher the melting temperature and the lower the consolidation temperature will act to forestall technetium loss.

Fugitive technetium may be a problem for both typical and atypical waste feed stocks. Even when aggressive recovery technologies are used to reclaim lost technetium from the melter and related apparatus, the loss of technetium to the environment is still likely to be approximately 2 percent (Darab and Smith 1996). Loss of 2 percent of the total technetium budget translates to roughly $26 \mathrm{~kg}$ or $460 \mathrm{Ci}$, which would be an unacceptable release to the environment.

Dissolution of technetium-bearing glass in the disposal environment will likely result in the release of technetium at nearly the same rate at which other glass components are released (Pierce et al. 2006; Pirlet 2001). Once released from glass, the mobility of technetium will be dictated by the redox conditions of the sediments and associated pore solutions. If the conditions are oxidizing, then there is an expectation that the mobile $\mathrm{TcO}_{4}{ }^{-}$anion will travel virtually unimpeded through the sediments. On the other hand, if conditions are reducing enough, then Tc(IV) will either sorb onto solid phases that make up the sediments, or will precipitate as the relatively insoluble $\mathrm{TcO}_{2} \cdot n \mathrm{H}_{2} \mathrm{O}_{(\mathrm{s})}$ compounds (where $n=1.6$ to 2.0). However, the presence of neo-formed iron phases on the surface of enclosing metallic canisters may exert a strong affect on technetium retention. Pirlet (2001) found that concentrations of technetium in solution were a factor of 100 times less when magnetite, as a surrogate for oxidized canister materials, was present along with the glass. Other experimental studies (Krupka et al. 2006), using rhenium as an analog for technetium, also showed that interaction of rhenium with corrosion products is significant and can be construed to indicate significant retardation of technetium mobility.

It is not clear at this juncture if the redox state of technetium in glass will influence its rate of release from glass interacting with aqueous solutions. While relevant data are lacking, it is possible to speculate that even if technetium were present in the $\mathrm{Tc}(\mathrm{IV}) \mathrm{O}_{6}$ form, diffusion of water into glass ahead of the alteration front would likely result in oxidation to $\mathrm{Tc}(\mathrm{VII})$. The mobility of technetium would thus be tied to how fast water diffuses into glass coupled with the removal of $\mathrm{Tc}(\mathrm{VII})$ from the glass matrix. The only relevant study on this subject was reported by McKeown et al. (2007), who showed that a glass sample containing oxidized technetium (pertechnetate) exposed to a vapor hydration test at $238^{\circ} \mathrm{C}$ for 24.9 days, exhibited a buildup of technetium near the surface of the reacted glass coupon. Interestingly, these investigators showed that technetium near the surface appeared to be in the reduced state, based upon XANES data. The spectra collected for the glass surface was consistent with the presence of technetium in the form of amorphous $\mathrm{TcO}(\mathrm{IV})_{2} \cdot n \mathrm{H}_{2} \mathrm{O}_{(\mathrm{s})}$ and $\mathrm{Tc}(\mathrm{IV}) \mathrm{O}_{6}$. These data indicate that, in the glassy environment, $\mathrm{Tc}(\mathrm{IV})$ is less mobile than $\mathrm{Tc}(\mathrm{VII})$. However, it is not readily apparent if these results are applicable to the disposal environment, since dissolution took place under reducing conditions (argon atmosphere) that likely affected the redox state of the technetium near the surface. Clearly, more tests specifically designed to elucidate the behavior of technetium in glass exposed to aqueous solution are necessary. 


\subsection{Research Isotopes of Technetium}

A number of the longer-lived isotopes, such as ${ }^{95 \mathrm{~m}} \mathrm{Tc}$ and ${ }^{99 \mathrm{~m}} \mathrm{Tc}^{1}$, have a number of research applications, especially in the medical field. Most artificially-produced technetium, including ${ }^{99 \mathrm{~m}} \mathrm{Tc}$, which is widely used in medical imaging, results from neutron or deuteron bombardment of various isotopes of molybdenum, and to a lesser extent, niobium and ruthenium. Even though 150,000 Ci of medical tests are performed with ${ }^{99 \mathrm{~m}} \mathrm{Tc}$ each year (with the decay product of ${ }^{99} \mathrm{Tc}$ ), medical isotopes represent only a small fraction of ${ }^{99} \mathrm{Tc}\left(1 \mathrm{Ci}{ }^{99 \mathrm{~m}} \mathrm{Tc}\right.$ decays to $\left.3 \mathrm{nCi}{ }^{99} \mathrm{Tc}\right)$ that could potentially be released to the environment (Jurisson et al. 2004; Wildung et al. 1979). For example, the average amount of ${ }^{99} \mathrm{Tc}$ released to the sea by the Sellafield, United Kingdom reprocessing plant after 1980 is $4.6 \mathrm{TBq} / \mathrm{y}$, which is a factor of $2.8 \times 10^{5}$ more than that released through medical diagnostic testing worldwide.

\footnotetext{
${ }^{1}$ The designation " $m$ " refers to the metastable isomer. An isomer possesses a higher energy state in its nucleon than the lower-energy isotope of the same mass and decays to the ground state isomer by means of an isomeric transition. In this case, the isotope ${ }^{99} \mathrm{Tc}$ is the ground state, and is sometimes designated as " ${ }^{~}{ }^{99 \mathrm{~g}} \mathrm{Tc}$ " in the literature.
} 


\subsection{Chemistry of Element $\mathbf{4 3}$}

Technetium resides in column seven, sometimes also called VIIB, in the periodic table sandwiched between manganese above and rhenium below (Figure 3.1). The similarity between elements in this column comes from similar electronic structure; all elements have a partially filled $d$-shell comprising electrons that have nearly the same energies as the outermost $s$-shell electrons. Elements that reside to the left and right of technetium (molybdenum and ruthenium), and down to the left and right (tungsten and osmium) also have a similar arrangement of $d$ - and $s$-shell electrons. Thus, a defining characteristic of " $d$-block" elements is that they have $d$-shell electrons that participate along with $s$-shell electrons in bonding and reaction. In many ways, therefore, the behavior of this set of elements (chromium, manganese, iron, molybdenum, technetium, ruthenium, tungsten, rhenium, and osmium) is similar.

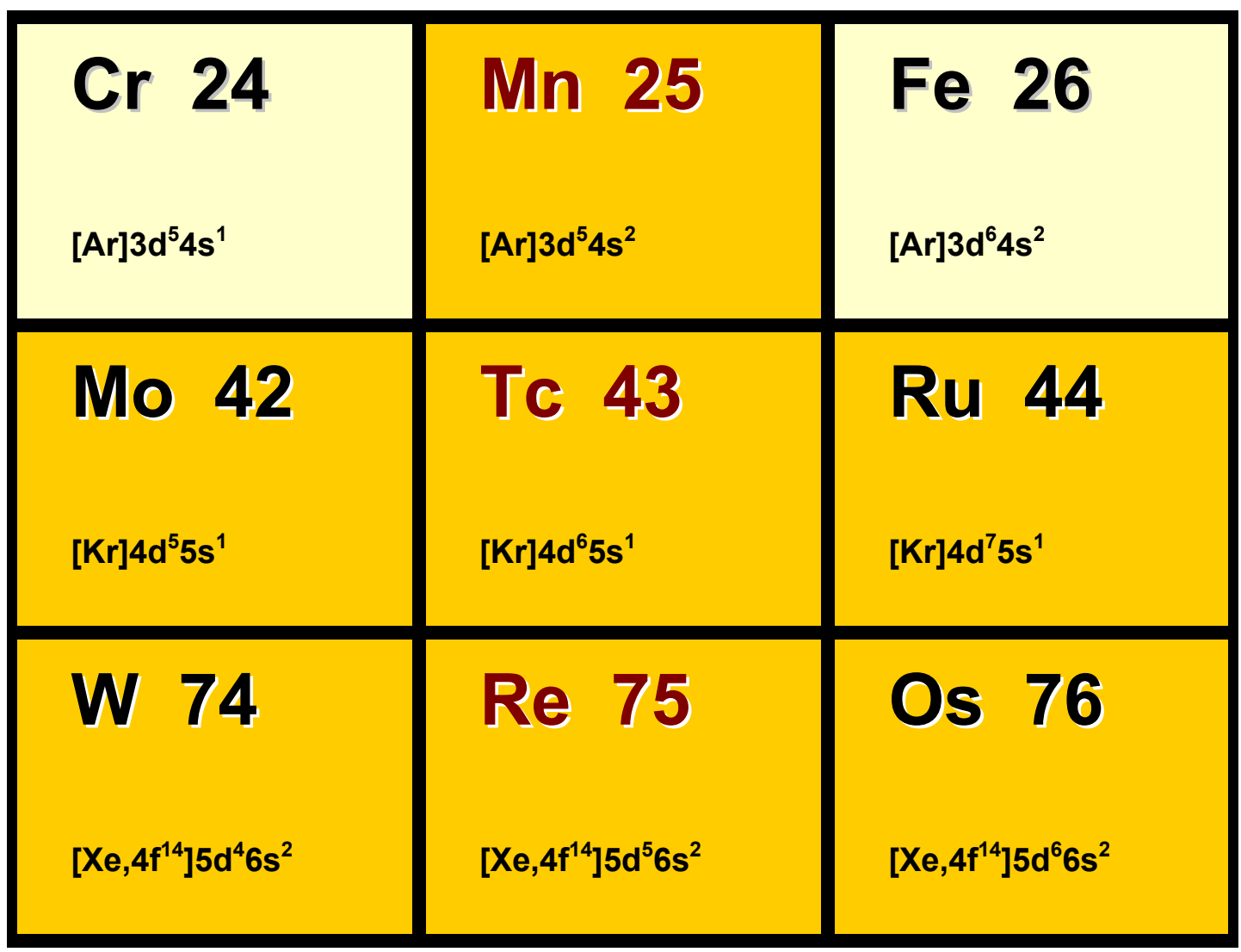

Figure 3.1. Block Diagram Indicating the Relative Positions of Technetium and Congeners in the Periodic Table. The number next to the atomic symbol is the atomic number of the element and below it is the electronic structure of each atom. Red symbols and atomic numbers represent the elements of column VIIB in the Periodic Table. Data from Huheey et al. 1993.

An example of this is the hydrolysis of these metals and formation of anionic complexes. Chromate $\left(\mathrm{CrO}_{4}{ }^{2-}\right)$, molybdate $\left(\mathrm{MoO}_{4}{ }^{2-}\right)$, ruthenate $\left(\mathrm{RuO}_{4}{ }^{2-}\right)$, tungstate $\left(\mathrm{WO}_{4}{ }^{2-}\right)$, rhenate $\left(\mathrm{ReO}_{4}{ }^{2-}\right)$, and osmate $\left[\mathrm{OsO}_{4}(\mathrm{OH})_{4}{ }^{2-}\right]$ have similar molecular structures, as do the permanganate $\left(\mathrm{MnO}_{4}{ }^{-}\right)$, pertechnetate $\left(\mathrm{TcO}_{4}{ }^{-}\right)$, perrhenate $\left(\mathrm{ReO}_{4}^{-}\right)$, perruthenate $\left(\mathrm{RuO}_{4}^{-}\right)$, and perosmate $\left[\mathrm{OsO}_{4}(\mathrm{OH})_{2}{ }^{2-}\right]$. 
Figure 3.1 also lists the electronic structures of the nine elements noted above. The short-hand way of writing the electronic structures of the elements is to write the noble gas "core" as a prefix followed by the electronic structure of the outermost electrons.

As mentioned above, all the elements identified in this study have outermost electrons in a $d$-shell, which has a capacity for 10 electrons, and comports to these elements a number of characteristic properties. For example, all the elements in this list, and those assigned to the group of transition elements in general, exhibit multiple oxidation states (Table 3.1). In the case of technetium, oxidation states of -1 to +7 are possible, although the most common oxidation states are +4 and +7 , as discussed below. Table 3.1 lists the common oxidation states of the eight congeners of technetium. Note that the "common" oxidation states are neither a list of all possible oxidation states nor a sequence of all environmentally relevant cations, but simply the most typical. For example, hexavalent chrome $\left(\mathrm{Cr}^{6+}\right)$ is an element of environmental concern that exists in a number of metal-contaminated sites, even though divalent chrome $\left(\mathrm{Cr}^{2+}\right)$ is the most stable oxidation state of chromium. Also note that the elements with larger atomic numbers tend to exist in higher oxidation states (e.g., tungsten, rhenium, and osmium) than those directly above them in the periodic table. Table 3.1 also tabulates the (first) ionization energies and electronegativities of the nine elements. Both ionization energies and electronegativities trend towards higher values from chromium down to osmium, but are numerically similar.

Table 3.1. Chemical and Electronic Properties of Technetium and Similar Elements. Data from Huheey et al. 1993, and Pauling 1947.

\begin{tabular}{ccccccc}
\hline Element & $\begin{array}{c}\text { Atomic } \\
\text { Number }\end{array}$ & $\begin{array}{c}\text { Common Oxidation } \\
\text { States }\end{array}$ & $\begin{array}{c}\text { Atomic } \\
\text { Weight }\end{array}$ & $\begin{array}{c}\text { Ionization Energy } \\
(\mathrm{kJ} / \mathrm{mol})\end{array}$ & $\begin{array}{c}\text { Atomic Radii } \\
(\AA)\end{array}$ & $\begin{array}{c}\text { Electro- } \\
\text { negativity }\end{array}$ \\
\hline $\mathrm{Cr}$ & 24 & $2+$ & 51.996 & 653 & 1.27 & 1.6 \\
$\mathrm{Mn}$ & 25 & $2+$ & 54.938 & 718 & 1.26 & 1.5 \\
$\mathrm{Fe}$ & 26 & $3+$ & 55.847 & 763 & 1.26 & 1.8 \\
$\mathrm{Mo}$ & 42 & $4+, 5+, 6+$ & 95.940 & 694 & 1.39 & 1.8 \\
$\mathrm{Tc}$ & 43 & $4+, 7+$ & 98.913 & 720 & 1.36 & 1.9 \\
$\mathrm{Ru}$ & 44 & $3+, 4+$ & 101.070 & 711 & 1.34 & $2.2^{(\mathrm{a})}$ \\
$\mathrm{W}$ & 74 & $5+, 6+$ & 183.850 & 771 & 1.39 & 1.7 \\
$\mathrm{Re}$ & 75 & $3+, 4+, 7+$ & 186.207 & 761 & 1.37 & 1.9 \\
$\mathrm{Os}$ & 76 & $4+, 6+, 8+$ & 190.200 & 842 & 1.35 & $2.2^{(\mathrm{a})}$ \\
\hline
\end{tabular}

(a) From Griffith 1967.

Because the outermost $d$ - and $s$-shell electrons have nearly the same energies, shielding of the nucleus has similar effects, one of which is that there is little difference in size of the element or cation within the group. Table 3.2 lists the atomic radii of the neutrally charged metals in 12-fold coordination; the values of the radii only range from 1.26 to 1.39 angstroms (less than 10 percent variation). 
Table 3.2. List of Cationic Radii of the VI, VII, and VIIIB Block Elements in picometers (pm). The coordination number refers to the number of associated ligands and LS and HS stand for "low spin" and "high spin" configurations, respectively. Data from Huheey et al. 1993.

\begin{tabular}{|c|c|c|c|}
\hline Element & Cation & Coordination Number & Radii (pm) \\
\hline \multirow[t]{4}{*}{ Iron } & $\mathrm{Fe}^{2+}$ & $6, \mathrm{LS}$ & 75 \\
\hline & & $6, \mathrm{HS}$ & 92 \\
\hline & $\mathrm{Fe}^{3+}$ & 6, LS & 69 \\
\hline & & $6, \mathrm{HS}$ & 78.5 \\
\hline \multirow[t]{3}{*}{ Chromium } & $\mathrm{Cr}^{3+}$ & 6 & 75.5 \\
\hline & $\mathrm{Cr}^{4+}$ & 4 & 55 \\
\hline & $\mathrm{Cr}^{6+}$ & 6 & 69 \\
\hline \multirow[t]{8}{*}{ Manganese } & $\mathrm{Mn}^{2+}$ & 6, LS & 80 \\
\hline & & $6, \mathrm{HS}$ & 90 \\
\hline & $\mathrm{Mn}^{3+}$ & 6, LS & 72 \\
\hline & & $6, \mathrm{HS}$ & 78.5 \\
\hline & $\mathrm{Mn}^{4+}$ & 4 & 53 \\
\hline & & 6 & 67 \\
\hline & $\mathrm{Mn}^{7+}$ & 4 & 39 \\
\hline & & 6 & 60 \\
\hline \multirow[t]{3}{*}{ Molybdenum } & $\mathrm{Mo}^{4+}$ & 6 & 79 \\
\hline & $\mathrm{Mo}^{6+}$ & 4 & 55 \\
\hline & & 6 & 73 \\
\hline \multirow[t]{2}{*}{ Osmium } & $\mathrm{Os}^{4+}$ & 6 & 77 \\
\hline & $\mathrm{Os}^{6+}$ & 6 & 68.5 \\
\hline \multirow[t]{3}{*}{ Rhenium } & $\operatorname{Re}^{4+}$ & 6 & 77 \\
\hline & $\operatorname{Re}^{7+}$ & 4 & 52 \\
\hline & & 6 & 67 \\
\hline \multirow[t]{2}{*}{ Ruthenium } & $\mathrm{Ru}^{4+}$ & 6 & 76 \\
\hline & $\mathrm{Ru}^{7+}$ & 4 & 52 \\
\hline \multirow[t]{3}{*}{ Technetium } & $\mathrm{Tc}^{4+}$ & 6 & 78.5 \\
\hline & $\mathrm{Tc}^{7+}$ & 4 & 51 \\
\hline & & 6 & 70 \\
\hline \multirow[t]{3}{*}{ Tungsten } & $\mathrm{W}^{4+}$ & 6 & 56 \\
\hline & $\mathrm{W}^{6+}$ & 4 & 56 \\
\hline & & 6 & 62 \\
\hline
\end{tabular}


The similarity in size also extends to the cations as well, provided that charge and the number coordinating ligands are the same (Table 3.2). This attribute mimics the trends in the "lanthanide contraction", in which rare earth elements are essentially the same size, decreasing slowly in ionic radii from lanthanum to lutetium. Thus, for example, the ionic radii of the $\mathrm{M}^{4+}$ cations in 6-fold coordination are $67,79,77,76,78.5$, and 80 picometers for manganese, molybdenum, rhenium, ruthenium, technetium, and tungsten, respectively. Because the similarity in radii of $\mathrm{Tc}^{4+}$ and the common cations, such as $\mathrm{Fe}^{2+}, \mathrm{Fe}^{3+}$ and $\mathrm{Mn}^{2+}$, there is a good prospect that the reduced form of technetium can "camouflage" in sites in iron- or manganese-bearing solids. This possibility will be discussed further below. For the heptavalent $\left(\mathrm{M}^{7+}\right)$ cations in 4-fold coordination, the ionic radii are $39,52,52$, and 51 picometers for manganese, rhenium, ruthenium, and technetium, respectively. Therefore, the behavior of these elements in environments typical of near-surface aqueous settings, are similar.

Technetium metal $[\operatorname{Tc}(0)]$ crystallizes with hexagonal closest packing (hcp), which is the same for rhenium, ruthenium, and osmium (Kotegov et al. 1968). The unit cell contains two atoms with a radius of $1.358 \AA$. Based on an atomic weight of 99, the density of technetium metal is $11.497 \mathrm{~g} / \mathrm{cc}$ (Mooney 1948). Both manganese and rhenium atoms possess similar sizes (1.306 $\AA$ and $1.373 \AA$ ). Although the atomic radii are similar, the radii of the heptavalent $(+7)$ cations display major differences between technetium and rhenium on the one hand (both $0.56 \AA$ ), and manganese on the other $(0.46 \AA)$ (Kotegov et al. 1968). For the cations in the heptavalent oxidation state, the metal-oxygen bond lengths show a similar pattern. The Tc(VII) - O and Re(VII) - O bond lengths are $1.711 \AA$ and $1.737 \AA$, respectively (Faggiani et al. 1980), whereas that of $\mathrm{Mn}-\mathrm{O}$ is $1.607 \AA$ (Krebs and Hasse 1976), which is significantly shorter. Pertechnetate and perrhenate salts containing the relatively small $\mathrm{NH}_{4}{ }^{+}$and $\mathrm{Na}^{+}$units are tetragonal and crystallize in the scheelite structure $\left(\mathrm{CaWO}_{4}\right)($ Colton 1965), whereas both cesium salts are orthorhombic. The bond lengths of the reduced oxides, i.e., $\mathrm{Tc}(\mathrm{IV})-\mathrm{O}$ and $\mathrm{Re}(\mathrm{IV})-\mathrm{O}$, are very similar (1.99 $\AA$ and $1.94 \AA$, respectively). However, there are differences in coordination: technetium is coordinated by 6 and rhenium by 4 oxygen atoms (Wharton et al. 2000). In the sulfide system, the $\mathrm{Tc}(\mathrm{IV})$ - $\mathrm{S}$ and $\mathrm{Re}(\mathrm{IV})$ - $\mathrm{S}$ bond lengths are indistinguishable in length $(2.33 \AA)$ and coordination number

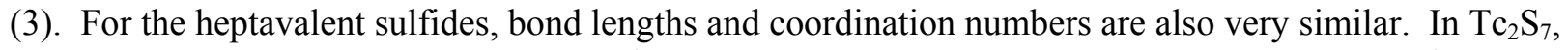
the $\mathrm{Tc}(\mathrm{VII})-\mathrm{S}$ bond has a length at $2.39 \AA$ (4-fold coordinated) and a Tc-Tc distance of $2.78 \AA$. Nearly identical bonding has been measured in $\operatorname{Re}_{2} \mathrm{~S}_{7}: 4 \mathrm{~S}$ bonds at $2.37 \AA$ and a $\mathrm{Re}-\mathrm{Re}$ distance of $2.76 \AA$ (Wharton et al. 2000). Despite these subtle differences, $\mathrm{Tc}_{2} \mathrm{~S}_{7}$ and $\mathrm{Re}_{2} \mathrm{~S}_{7}$ are reportedly isomorphous (Cotton and Wilkinson 1980).

The bond lengths of the other congeners of technetium are quite similar; the $\mathrm{Ru}-\mathrm{O}$ and $\mathrm{Os}-\mathrm{O}$ bond lengths are $1.706 \AA$ and $1.712 \AA$ for the perrhenate and perosmate ions, respectively. Like Tc(IV), $\mathrm{Mo}(\mathrm{IV}) \mathrm{O}_{2}$ has 6 oxygen nearest neighbors surrounding molybdenum. Although structurally different, the $\mathrm{Mo}-\mathrm{O}$ and $\mathrm{W}-\mathrm{O}$ bonds in the $\mathrm{MoO}_{4}{ }^{2-}$ and $\mathrm{WO}_{4}{ }^{2-}$ anions are $1.77 \AA$ and $1.78 \AA$, respectively (Krebs and Hasse 1976). In general, although ionic radii and bond lengths are similar amongst the congeners of technetium, difference in chemical behavior exists because of the charge density (charge per radius squared) possessed by each. Because the $d^{0}$ elements undergo a contraction of the radii across the dblock, similar to that for the rare earths, changes in charge density will lead to differences in behavior.

There are other subtle differences between elements in column VIIB, which includes manganese, technetium, and rhenium, and these are worth mentioning. Although manganese can have oxidation states as high as $+7, \mathrm{Mn}$ (II) is the most stable state, especially in the high-spin state. In contrast, both rhenium and technetium are stable as the heptavalent cation, although differences exist between the ease of reduction of these two cations (see below). The dioxides $\mathrm{TcO}_{2}, \mathrm{ReO}_{2}$, and $\mathrm{MoO}_{2}$ all possess the 
distorted rutile structure, but $\mathrm{MnO}_{2}$ is not isomorphous (Colton 1965). Similarly, $\mathrm{TcS}_{2}$ and $\mathrm{ReS}_{2}$ are isomorphous and are similar in structure to $\mathrm{MoS}_{2}$ (Kotegov et al. 1968). Whereas the pertechnetate and perrhenate ions are stable in alkaline solutions, the permanganate ion is not.

In the more reduced compounds, there are fewer similarities between technetium and rhenium compounds, however. For example, $\mathrm{Re}(\mathrm{III})$ is stable over a wide range of $\mathrm{pH}-E_{\mathrm{h}}$ conditions (see below), but $\mathrm{Tc}(\mathrm{III})$ is not. Further, $\operatorname{Re}(\mathrm{V})$ compounds are known to exist, but $\mathrm{Tc}(\mathrm{V})$ and $\mathrm{Tc}(\mathrm{VI})$ compounds do not exist unless stabilized by organic ligands. Instead, $\mathrm{Tc}(\mathrm{V})$ and $\mathrm{Tc}(\mathrm{VI})$ tend to disproportionate rapidly into Tc(IV) and Tc(VII):

$$
\begin{aligned}
& 3 \mathrm{Tc}(\mathrm{V}) \rightarrow 2 \mathrm{Tc}(\mathrm{IV})+\mathrm{Tc}(\mathrm{VII}) \\
& 3 \mathrm{Tc}(\mathrm{VI}) \rightarrow \mathrm{Tc}(\mathrm{IV})+2 \mathrm{Tc}(\mathrm{VII})
\end{aligned}
$$

The lifetime of either $\mathrm{Tc}(\mathrm{V})$ or $\mathrm{Tc}(\mathrm{VI})$ is short, especially in oxidizing environments. For example, the half-life of Tc(VI) in air is only approximately $10 \mathrm{msec}$ (Cotton and Wilkinson 1980), so it is likely that only $\mathrm{Tc}$ (VII) and Tc(IV) species will be found in nature. In the heptavalent state, $\mathrm{Re}_{2} \mathrm{O}_{7}$ is deliquescent and consists of $\mathrm{ReO}_{4}$ tetrahedra and $\mathrm{ReO}_{6}$ octahedra in corner-sharing arrays. In contrast, $\mathrm{Tc}_{2} \mathrm{O}_{7}$ is made up of $\mathrm{TcO}_{4}$ tetrahedra in which the tetrahedra share an oxygen atom and the $\mathrm{Tc}-\mathrm{O}-\mathrm{Tc}$ chain is linear. 



\subsection{Use of Rhenium as a Geochemical Analog of Technetium}

Despite the similarities in cationic size and in geochemical behavior, there may be some reasons why using rhenium as an analog of technetium in experiments or tracer studies might yield incorrect conclusions. Kim and Boulègue (2003) investigated the dissolution behavior of Re-oxides in which rhenium had oxidation states of $+7,+4$, and +3 (or VII, IV, and III, respectively) over a $\mathrm{pH}$ and $E_{\mathrm{h}}$ interval.

Like technetium, Re-oxide solubility depends on both $\mathrm{pH}$ and $E_{\mathrm{h}}$ of the aqueous solution. Under oxidizing conditions, rhenium exists as the perrhenate $\left(\mathrm{ReO}_{4}{ }^{-}\right)$anion, just as the pertechnetate anion $\left(\mathrm{TcO}_{4}{ }^{-}\right.$ ) is the dominant species under similar conditions. On the other hand, $\operatorname{Re}(\mathrm{III})$ compounds, such as $\operatorname{Re}_{2} \mathrm{O}_{3}$, $\mathrm{ReO}_{3}$ are stable, but no similar Tc(III) solids are stable. Dissolution of $\mathrm{ReO}_{2}$ showed no dependence on $\mathrm{pH}$, and the presence of oxygen did not appear to affect its solubility. The lack of dependence of dissolution on oxygen partial pressure makes the behavior of $\mathrm{ReO}_{2}$ different from that of $\mathrm{TcO}_{2}$; Lieser et al. (1987) reported that $\mathrm{TcO}_{2}$ dissolution is strongly dependent upon the presence of oxygen. Dissolution in neutral $\mathrm{pH}$ regimes releases neutral species of $\mathrm{Re}$, just as in the case of technetium:

$$
\mathrm{ReO} 2(\mathrm{cr})+\mathrm{H}_{2} \mathrm{O} \leftrightarrow \mathrm{ReO}(\mathrm{OH})_{2}{ }^{\circ}(\mathrm{aq})
$$

At higher $\mathrm{pH}$ values (i.e., greater than 9), the specie $\mathrm{ReO}(\mathrm{OH})_{3}$ may begin to form, which is behavior similar to that of technetium. Kim and Boulègue (2003) argue that Re(III) solids are unstable and persist metastably. The instability of Re(III) solids in aqueous solution does not result in the precipitation of $\mathrm{ReO}_{2}$, although concentrations of $\mathrm{Re}(\mathrm{aq})$ are high enough to saturate in this phase. Instead, the authors argue that dissolution of $\operatorname{Re}(\mathrm{III})$ results in the formation of $\mathrm{Re}(\mathrm{IV})$ polymers or colloids that forestalls the precipitation of $\mathrm{ReO}_{2}$. Again, this characteristic is similar to that of technetium, in which dimers $\left[\mathrm{TcO}(\mathrm{OH})_{2}{ }^{\circ}\right]_{2}$ form at concentrations greater than $10^{-5} \mathrm{~mol} / \mathrm{L}$ (Maes et al. 2004). Thus, the data in this study indicate that $\mathrm{ReO}_{2}$ (cr) has a larger stability field than previously thought and is therefore closer in behavior to technetium than realized. The stability of $\mathrm{ReO}_{2}(\mathrm{cr})$ in anoxic waters is reflected in its low solubility value of $4 \times 10^{-7}-10^{-6} \mathrm{~mol} / \mathrm{L}$ (Kim and Boulègue 2003). This compares well with the solubility values of $\mathrm{TcO}_{2}(\mathrm{cr})\left(\sim 10^{-8}\right)$ and $\mathrm{TcO}_{2}(\mathrm{am})\left(10^{-7}-10^{-6} \mathrm{~mol} / \mathrm{L}\right)$.

Figure 4.1, which was taken from Darab and Smith (1996), displays the $E_{\mathrm{h}}$-pH diagrams for technetium and the corresponding one for rhenium. The differences between the sizes of the $\mathrm{TcO}_{2}$ and $\mathrm{ReO}_{2}$ fields are apparent, as are the lack of corresponding $\mathrm{TcO}_{3}$ or $\mathrm{Tc}_{2} \mathrm{O}_{3}$ stability fields.

A modeling investigation contrasting technetium and rhenium sorption onto iron and sulfur-bearing minerals was carried out by Anderson et al. (2007). The authors were motivated by the possibility that rhenium and technetium behave differently in systems in which redox conditions become prominent. They note that compounds stable in $E_{\mathrm{h}}-\mathrm{pH}$ diagrams are not the same in the rhenium and technetium systems, as discussed above. While $\mathrm{TcO}_{4}{ }^{-}$is in equilibrium with $\mathrm{TcO}_{2}$ over a wide area in $E_{\mathrm{h}}-\mathrm{pH}$ space, $\mathrm{ReO}_{4}{ }^{-}$is in equilibrium with $\mathrm{Re}_{2} \mathrm{O}_{3}$ and $\mathrm{ReO}_{3}$ (see Figure 4.1). They also note that rhenium and technetium exhibit different behavior on mackinawite (FeS) surfaces (Wharton et al. 2000). Part of the difference between the two elements may be a reflection of their chemical properties, such as their binding energies. Respectively, the binding energy of $\mathrm{TcO}_{4}{ }^{-}$and $\mathrm{ReO}_{4}{ }^{-}$is -388.7 and $-371.1 \mathrm{eV}$. However, bond lengths of $\mathrm{Tc}-\mathrm{O}$ and $\mathrm{Re}-\mathrm{O}$ are nearly the same (1.71 $\AA$, and $1.74 \AA$, respectively), as are their hydration energies $(-2.4 \mathrm{eV}$ and $-2.5 \mathrm{eV}$, respectively). 
a. technetium

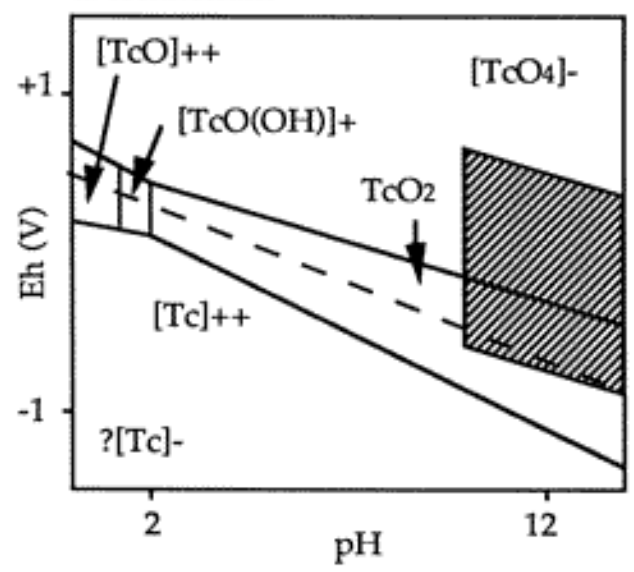

b. rhenium

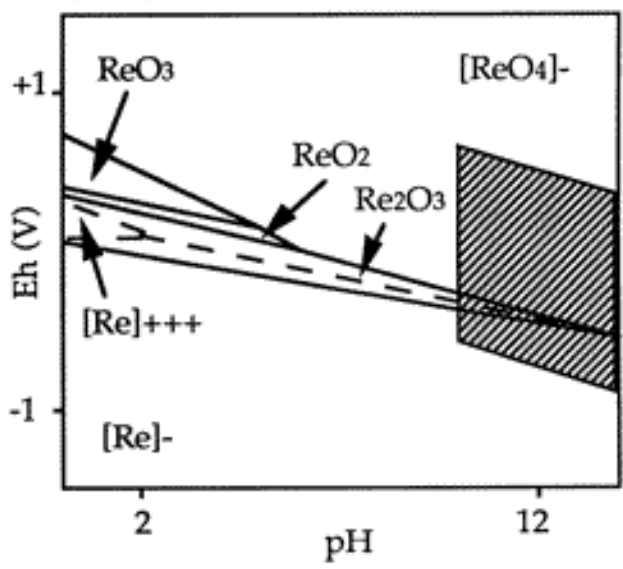

Figure 4.1. $E_{\mathrm{h}}-\mathrm{pH}$ Diagrams for (a) Technetium and (b) Rhenium. Note that the stability field of $\mathrm{TcO}_{2}$ is much larger than that of $\mathrm{ReO}_{2}$ and that there is no stability field for $\mathrm{Tc}$ (III) species. The shaded boxes represent the $E_{\mathrm{h}}-\mathrm{pH}$ conditions expected in the tank waste environment. From Darab and Smith (1996).

The modeling exercise that they conducted was based on a quantum mechanical program (Gaussian03). Calculations show that on galena terrace surfaces, $\mathrm{TcO}_{4}{ }^{-}$and $\mathrm{ReO}_{4}{ }^{-}$sorption was similar. On the other hand, $\mathrm{TcO}_{4}{ }^{-}$will be reduced by galena near step edges, but $\mathrm{ReO}_{4}{ }^{-}$will not. In the presence of other ions $\left(\mathrm{Na}^{+}, \mathrm{Cl}^{-}\right.$, and chlorine-complexes), both $\mathrm{TcO}_{4}{ }^{-}$and $\mathrm{ReO}_{4}{ }^{-}$sorption is unfavorable in the presence of chlorine, but favorable in the presence of sodium. However, the behavior of the rhenium and technetium chlorine complexes may be very different, as shown through the rather large difference in energies between the two $(20 \mathrm{eV}$, in some cases $)$.

A series of sorption experiments were conducted by Krupka et al. (2006) to determine the partitioning of technetium between steel materials, their corrosion products, and solution. The experiments used rhenium as a non-radioactive analogue of technetium, but results of other tests using technetium were also discussed. The authors found that rhenium sorbs onto or is co-precipitated with corrosion products, such as goethite $[\alpha-\mathrm{Al}(\mathrm{O})(\mathrm{OH})]$, lepidocrocite $[\gamma-\mathrm{Al}(\mathrm{O})(\mathrm{OH})]$, and maghemite $\left(\gamma-\mathrm{Fe}_{2} \mathrm{O}_{3}\right)$ as $\mathrm{Re}(\mathrm{VII})$. This behavior contrasts with that of technetium, in which sorption takes place as $\mathrm{Tc}(\mathrm{IV})$, rather than $\mathrm{Tc}(\mathrm{VII})$. Because of the low solubility of $\mathrm{TcO}_{2}$-type compounds, technetium precipitates or forms a co-precipitate with $\mathrm{Fe}(\mathrm{III})$ minerals. Krupka et al. (2006) suggest that the standard potential of the $\operatorname{Re}(\mathrm{VII}) / \operatorname{Re}(\mathrm{IV})$ couple is significantly lower than that for $\mathrm{Tc}(\mathrm{VII}) / \mathrm{Tc}(\mathrm{IV})$, which indeed it is. The oxidation potential of the former is $-0.510 \mathrm{~V}$, whereas the latter has a value of $-0.738 \mathrm{~V}$, according to Kotegov et al. (1968).

In summary, Anderson et al. (2007) and Krupka et al. (2006) conclude that perrhenate and pertechnetate behave similarly under many environmental conditions, except where electron transfers are involved. In these cases, the two elements behave very differently. Also, the differences in complexation energies between the chloride species of rhenium and technetium may render the usefulness of the chemical analogy void. Complexation of technetium with chloride results in a higher solubility, whereas the chloride complexes of rhenium results in virtually no difference in solubility, as confirmed by experiment by Xiong and Wood (1999). 


\subsection{Radiochemistry-the Isotopes and Isomers of Technetium}

As previously mentioned, all technetium isotopes are anthropogenic, except a small amount of technetium that forms by spontaneous fission in uranium ores. The two principle ways to make technetium is by fission of ${ }^{235} \mathrm{U}$ (as well as ${ }^{239,241} \mathrm{Pu}$ ) or activation of molybdenum metal by neutrons or deuterons. The first isotopes of technetium that were discovered were ${ }^{95} \mathrm{Tc}$ and ${ }^{97} \mathrm{Tc}$, which were produced by bombardment of a thin metal sheet of molybdenum (Perrier and Segrè 1937a). Currently, there are 22 known isotopes of technetium with mass numbers from ${ }^{90} \mathrm{Tc}$ to ${ }^{111} \mathrm{Tc}$. For the most part, the half-lives of the technetium isotopes are short (seconds to days), with the exception of three. These are: ${ }^{97} \mathrm{Tc}$ with $t_{1 / 2}=2.6 \times 10^{6},{ }^{98} \mathrm{Tc}$ with $t_{1 / 2}=4.2 \times 10^{6}$, and ${ }^{99} \mathrm{Tc}$ with $t_{1 / 2}=2.14 \times 10^{5}$ years. Table 5.1 lists the most important isotopes, their mode of decay and half-lives. However, ${ }^{99} \mathrm{Tc}$ is a factor of $10^{11}$ times and $10^{6}$ times more abundant than ${ }^{97} \mathrm{Tc}$ and ${ }^{98} \mathrm{Tc}$, respectively (Luykx 1984). The reason for this is that the fission yield of technetium isotopes favors the heavier isotopes, starting with ${ }^{99} \mathrm{Tc}$. Of these isotopes, ${ }^{99} \mathrm{Tc}$ has a relatively high fission yield (approximately 6.06 percent; Table 5.2). As can be seen from Table 5.2, other isotopes of technetium have relatively high fission yields, but have half-lives that are too short for them to be environmentally relevant. Therefore, only ${ }^{99} \mathrm{Tc}$ has the combined attributes of high fission yield and relatively long half-life, which means that ${ }^{99} \mathrm{Tc}$ is the main isotope of environmental concern.

Table 5.1. A List of the Principle Technetium Isotopes and Isomers, Their Respective Half-Lives, Decay Mechanisms, Energies, and Decay Products. From Anders 1960.

\begin{tabular}{|c|c|c|c|c|}
\hline Technetium Isotope & Half-life & Decay Mechanism & Energy $(\mathrm{MeV})$ & Decay Product \\
\hline \multirow[t]{3}{*}{${ }^{95 \mathrm{~m}} \mathrm{Tc}$} & $61 \mathrm{~d}$ & $\mathrm{EC}$ & -- & ${ }^{95} \mathrm{Mo}$ \\
\hline & & $\gamma$ & $0.204,0.582,0.835$ & -- \\
\hline & & IT & $0.0389, \mathrm{e}$ & ${ }^{95} \mathrm{Tc}$ \\
\hline \multirow[t]{2}{*}{${ }^{96} \mathrm{Tc}$} & $4.3 \mathrm{~d}$ & $\mathrm{EC}$ & & ${ }^{96} \mathrm{Mo}$ \\
\hline & & $\gamma$ & $0.778,0.849,0.812$ & -- \\
\hline${ }^{97} \mathrm{Tc}$ & $2.6 \times 10^{6} \mathrm{y}$ & $\mathrm{EC}$ & -- & ${ }^{97} \mathrm{Mo}$ \\
\hline${ }^{97 \mathrm{~m}} \mathrm{Tc}$ & $90 \mathrm{~d}$ & IT & $0.965, \mathrm{e}$ & ${ }^{97} \mathrm{Tc}$ \\
\hline \multirow[t]{2}{*}{${ }^{98} \mathrm{Tc}$} & $4.2 \times 10^{6} \mathrm{y}$ & $\tilde{\beta}^{-}$ & 0.4 & ${ }^{98} \mathrm{Ru}$ \\
\hline & & $\gamma$ & $0.745,0.652$ & -- \\
\hline${ }^{99} \mathrm{Tc}$ & $2.12 \times 10^{5} \mathrm{y}$ & $\beta^{-}$ & 0.294 & ${ }^{99} \mathrm{Ru}$ \\
\hline \multirow[t]{2}{*}{${ }^{99 \mathrm{~m}} \mathrm{Tc}$} & $6.01 \mathrm{~h}$ & IT & $0.142,0.002$ & ${ }^{99} \mathrm{Tc}$ \\
\hline & & $\gamma$ & 0.14 & -- \\
\hline $\begin{array}{l}\text { Notes: } \\
\mathrm{EC}=\text { electron capture } \\
\text { IT = isomeric transition }\end{array}$ & $\begin{array}{l}\beta=1 \\
\gamma=g\end{array}$ & $\begin{array}{l}\text { lecay } \\
\text { a emission. }\end{array}$ & & \\
\hline
\end{tabular}


The specific activity of ${ }^{99} \mathrm{Tc}$ is $1.7 \times 10^{-2} \mathrm{Ci} / \mathrm{g}$, which translates to 37,800 disintegrations per minute per microgram. However, the low energy $\beta$ particle $\left(E_{\max }=0.292 \mathrm{MeV}\right)$ emitted by ${ }^{99} \mathrm{Tc}$ decay is difficult to detect by conventional counting methods, but a number of advances in liquid scintillation counting (LSC) and inductively-coupled plasma mass spectroscopy (ICP-MS) today make for routine analysis. It is interesting to note that in many early assays of environmental samples that total $\beta$ counts were reported in which the identity of the $\beta$ particles could not be distinguished. It is likely that many of these samples contained ${ }^{99} \mathrm{Tc}$ in addition to other $\beta$ emitters, such as ${ }^{137} \mathrm{Cs}$ and ${ }^{90} \mathrm{Sr}$, whose beta particle energies masked that of ${ }^{99} \mathrm{Tc}$.

In addition to the isotopes, there are seven identified isomers of technetium, in which the nucleon possesses a higher energy configuration than its daughter in the ground state with the same mass number. The isomers of technetium are written with the letter " $\mathrm{m}$ " after the mass number to designate the energetically metastable form: ${ }^{93 \mathrm{~m}} \mathrm{Tc},{ }^{94 \mathrm{~m}} \mathrm{Tc},{ }^{95 \mathrm{~m}} \mathrm{Tc},{ }^{96 \mathrm{~m}} \mathrm{Tc},{ }^{97 \mathrm{~m}} \mathrm{Tc},{ }^{99 \mathrm{~m}} \mathrm{Tc}$ and ${ }^{102 \mathrm{~m}} \mathrm{Tc}$. The isomer ${ }^{99 \mathrm{~m}} \mathrm{Tc}$ has applications in geochemical studies as a tracer and is also used extensively in medical isotope applications. According to the U.S. Environmental Protection Agency (EPA), approximately $10 \times 10^{6}$ medical imaging procedures are carried out every year using ${ }^{99 \mathrm{~m}} \mathrm{Tc}$ (EPA 2002). Neutron activation of ${ }^{99}$ Mo produces ${ }^{99 \mathrm{~m}} \mathrm{Tc}$ with a half-life of approximately 6 hours, which decays by $\beta$ emission (140 keV) to ${ }^{99} \mathrm{Tc}$, which in turn decays to ${ }^{99} \mathrm{Ru}$.

Table 5.2. A List of the Principle Technetium Isotopes Produced by Fission of ${ }^{235} \mathrm{U}$, Their Percent Yields, and Half-Lives. From Colton 1965.

\begin{tabular}{crrrrrrr}
\hline Technetium isotope: & ${ }^{99} \mathrm{Tc}$ & ${ }^{101} \mathrm{Tc}$ & ${ }^{102} \mathrm{Tc}$ & ${ }^{103} \mathrm{Tc}$ & ${ }^{104} \mathrm{Tc}$ & ${ }^{105} \mathrm{Tc}$ & ${ }^{107} \mathrm{Tc}$ \\
\hline Yield (\%) & 6.06 & 5.6 & 4.3 & 3.0 & 1.8 & 0.9 & 0.19 \\
Half-life & $2.12 \times 10^{5} \mathrm{yr}$ & $14.3 \mathrm{~min}$ & $4.5 \mathrm{~min}$ & $50 \mathrm{sec}$ & $18 \mathrm{~min}$ & $7.7 \mathrm{~min}$ & $<1 \mathrm{~min}$ \\
\hline Notes: ${ }^{99} \mathrm{Tc}$ decays at $37,800 \mathrm{dpm} / \mu \mathrm{g}$ and a specific activity of $1.7 \times 10^{-2} \mathrm{Ci} / \mathrm{g}$ & & & & \\
\hline
\end{tabular}




\subsection{Environmental Geochemistry}

An understanding of the behavior of technetium in the environment has been fashioned from studies in diverse fields such as soil science, marine chemistry, geochemistry, phytobiology and health physics (e.g., Brown et al. 1999; Goudard et al. 1998; Harms et al. 1999; Krijger et al. 2000; Lindahl et al. 2003; Uchida et al. 2000). For the most part, much of these data have remained in specialized journals and there has been little effort expended to marshal relevant facts together to advance the understanding of technetium in the geosphere.

\subsection{Redox Chemistry}

Because technetium is a redox-sensitive element and its solubility and mobility in subsurface pore waters depends on its oxidation state, a great deal of effort has gone into quantifying stability fields of the various technetium species in terms of $E_{\mathrm{h}}, \mathrm{pH}$, and oxidation potential. The fundamental measurement that describes the stability of reduced and oxidized technetium is the electromotive force (EMF) of the $\mathrm{TcO}_{4}{ }^{-} / \mathrm{TcO}_{2}$ couple.

A number of investigators have attempted to measure the EMF of the $\mathrm{TcO}_{4}{ }^{-} / \mathrm{TcO}_{2}$ couple, including Cobble et al. (1953), Cartledge and Smith (1955), Liebscher and Münze (1975) and Meyer and Arnold (1991). Rard et al. (1999) reviewed these studies and pointed out that several measurements were plagued by the presence of oxygen in the reaction cell, the lack of demonstrated achievement of steadystate conditions, or lack of evidence of reversibility. Note also that the $\mathrm{pH}$-range of the experiments were mainly between 1.05 and 3.99; only two measurements were conducted at $\mathrm{pH}$ greater than 4.0. Approximately two thirds of the data discussed by Rard et al. (1999) were taken from Meyer and Arnold (1991), so the focus of this review will be on these data.

Meyer and Arnold (1991) determined by experiment the standard potential of the $\mathrm{TcO}_{4}{ }^{-} / \mathrm{TcO}_{2}$ couple, which is represented by:

$$
\mathrm{TcO}_{4}{ }^{-}+4 \mathrm{H}^{+}+3 \mathrm{e}^{-}=\mathrm{TcO}_{2}(\mathrm{~s})+2 \mathrm{H}_{2} \mathrm{O}
$$

They carefully minimized the oxygen fugacity by conducting the experiments in a controlled atmosphere argon box. Further, they kept the concentration of $\mathrm{TcO}_{4}{ }^{-}$low and precipitated $\mathrm{TcO}_{2} \cdot n \mathrm{H}_{2} \mathrm{O}$ by electrodeposition on a platinum mesh. Steady-state values were demonstrated, further lending credence to the measurements. The slopes of the plots of electrode potential versus. $\mathrm{pH}$ and activity of $\mathrm{TcO}_{4}{ }^{-}$were reported to be $-0.0773 \pm 0.0023 \mathrm{~V} / \mathrm{pH}$ unit (or $0.0211 \pm 0.0050 \mathrm{~V} / \log$ unit). The theoretical slope is $0.0788 \mathrm{~V} / \mathrm{pH}$ unit (or $0.01971 \mathrm{~V} / \log$ unit), so the measured value is within experimental uncertainty. From these data, the value of $E^{\circ}$ was reported to be $0.747 \pm 0.004 \mathrm{~V}$, and this value overlaps with the one advocated by Rard et al. (1999), which is $E=0.746 \pm 0.012 \mathrm{~V}$.

The thermochemical data derived from these measurements and from separate measurements discussed below (see section on Thermodynamics) yield the following $E_{\mathrm{h}}-\mathrm{pH}$ diagram for technetium in low carbonate, sulfate, and halide systems (Figure 6.1). 
Potentials for the elements directly above and below technetium in the periodic table are as follows (Kotegov et al. 1968):

$$
\begin{gathered}
\mathrm{MnO}_{4}{ }^{-} / \mathrm{MnO}_{2}: \mathrm{E}=1.695 \mathrm{~V} \\
\mathrm{ReO}_{4}{ }^{-} / \mathrm{ReO}_{2}: \mathrm{E}=0.510 \mathrm{~V}
\end{gathered}
$$

Therefore, the $\mathrm{TcO}_{4}-/ \mathrm{TcO}_{2}$ couple is more oxidizing than that of rhenium, but much less so than that for manganese. These data also show that $\mathrm{ReO}_{4}{ }^{-}$is more difficult to reduce than $\mathrm{TcO}_{4}{ }^{-}$, making some experiments in which rhenium is substituted for technetium difficult to interpret.

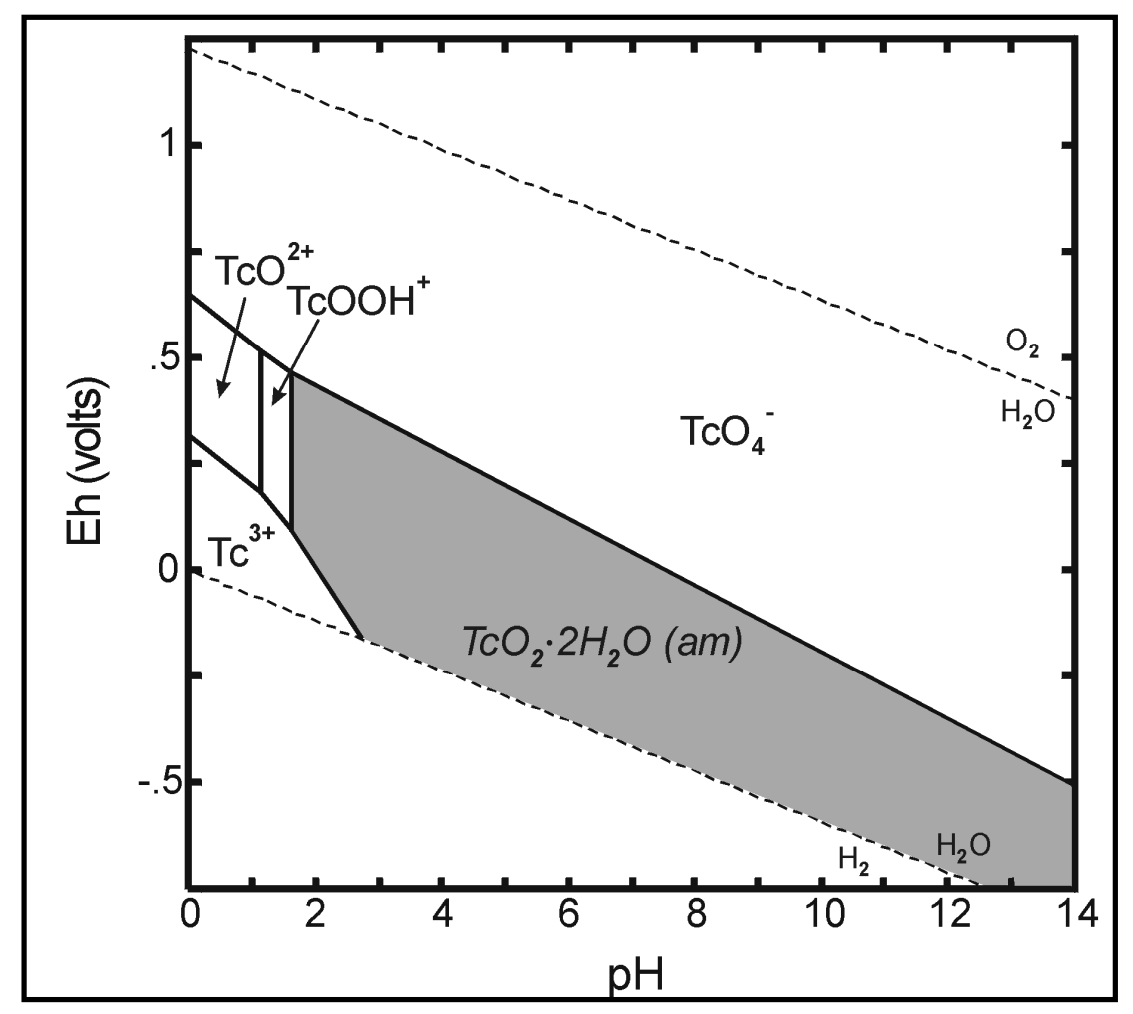

Figure 6.1. $E_{\mathrm{h}}-\mathrm{pH}$ Diagram for Technetium. The shaded area represents the region in which the amorphous solid, $\mathrm{TcO}_{2} \cdot 2 \mathrm{H}_{2} \mathrm{O}(\mathrm{am})$ is stable.

In the natural environment, retention or mobility of technetium depends mainly on the redox conditions of the system. For typical agricultural and horticultural soils, the $E_{\mathrm{h}}$ values range from 100 to $600 \mathrm{mV}$ and $\mathrm{pH}$ values of 4 to 8 (Koch-Steindl and Pröhl 2001). Table 6.21 lists the ranges of $E_{\mathrm{h}}$ and $\mathrm{pH}$ values in typical soils and subdivides the field into normal, wet, and waterlogged (in decreasing $E_{\mathrm{h}}$ ). This table also lists the corresponding biogeochemical zones (Burke et al. 2005). The kinds of redox reactions that take place in each are as follows (Koch-Steindl and Pröhl 2001). For normal soil, $\mathrm{NO}_{3}{ }^{-}$reduction begins between 550 to $450 \mathrm{mV}$, while $\mathrm{Mn}^{2+}$ formation is initiated between 450 to $350 \mathrm{mV}$. In wet soils, $\mathrm{O}_{2}$ and $\mathrm{NO}_{3}{ }^{-}$are no longer detectable (at 330 and $220 \mathrm{mV}$, respectively). Iron(II) begins to form around $150 \mathrm{mV}$. For waterlogged soil, $\mathrm{SO}_{4}{ }^{2-}$ and sulfide formation commences at $-50 \mathrm{mV}$. Methane begins to form at $-120 \mathrm{mV}$ and by $-180 \mathrm{mV}$, sulfate is no longer detectable. At neutral $\mathrm{pH}$ values $\mathrm{Tc}(\mathrm{VII})$ is reduced between 200 and $100 \mathrm{mV}$ (Lieser and Bauscher 1987), which is approximately the point at which nitrate disappears and Fe(II) begins to form. 
Table 6.1. Summary of Aeration Status of Soils and their Correspondence with Biogeochemical Zones

\begin{tabular}{|c|c|c|c|c|}
\hline Soil Aeration Status & Redox Reaction & $\begin{array}{l}E_{\mathrm{h} 7}{ }^{(\mathrm{a})} \\
(\mathrm{mV})\end{array}$ & Biogeochemical Zone & $\begin{array}{c}\Delta \mathrm{G}^{(\mathrm{b})} \\
(\mathrm{kJ} / \mathrm{mol})\end{array}$ \\
\hline \multirow[t]{3}{*}{ Well-aerated soils } & & & Oxic respiration & -856 \\
\hline & Initial nitrate reduction & $550-450$ & Nitrate reduction & -806 \\
\hline & Initial $\mathrm{Mn}^{2+}$ formation & $450-350$ & Manganese reduction & -569 \\
\hline \multirow[t]{4}{*}{ Wet soil } & $\mathrm{O}_{2}$ no longer detectable & 330 & & \\
\hline & Nitrate no longer detectable & 220 & & \\
\hline & Technetium reduction & $200-100$ & Technetium reduction & -436 \\
\hline & Initial $\mathrm{Fe}^{2+}$ formation & 150 & Iron reduction & -361 \\
\hline \multirow[t]{3}{*}{ Waterlogged soil } & Sulfate reduction & -50 & Sulfate reduction & -48 \\
\hline & Initial methane production & -120 & & \\
\hline & Sulfate no longer detectable & -180 & & \\
\hline
\end{tabular}

(a) $E_{\mathrm{h} 7}=$ the $E_{\mathrm{h}}$ at $\mathrm{pH} 7$

(b) Free-energy change per mole of acetate consumed as electron donor.

Notes: Data from Koch-Steindl and Pröhl 2001, Burke et al. 2005, and Lieser and Bauscher 1987.

For soils with $\mathrm{pH}$ between 7.5 and 5.5 and $E_{\mathrm{h}}$ values between 600 and $100 \mathrm{mV}$, plant growth is optimal (Koch-Steindl and Pröhl 2001). These conditions are also favorable for mobility of technetium as the pertechnetate anion. In many cases, however, technetium is present as a reduced species, as inferred from plant uptake studies (Echevarria et al. 1997; Tagami and Uchida 1997; Tagami and Uchida 1999; Vandecasteele et al. 1989; Vandecasteele et al. 1985). These departures from expected behavior are likely because of control by biogeochemical processes or reduction caused by the presence of organic matter. On the other hand, there are cases in which technetium persists in the oxidized form, even though the $E_{\mathrm{h}}$ of the system is below the reduction threshold. These conditions arise because of the availability and steric distribution of electron donors is more critical than the overall $E_{\mathrm{h}}$ of the system. For example, Cui and Eriksen (1996b) showed that even under conditions in which ferrous iron [Fe(II)] activity in solution were relatively high, reduction kinetics of Tc(VII) were sluggish. Therefore, even though the reduction reaction:

$$
\mathrm{Tc}(\mathrm{VII}) \mathrm{O}_{4}{ }^{-}+3 \mathrm{Fe}^{2+}+(n+7) \mathrm{H}_{2} \mathrm{O}=\mathrm{Tc}(\mathrm{IV}) \mathrm{O}_{2} \cdot n \mathrm{H}_{2} \mathrm{O}(s)+3 \mathrm{Fe}(\mathrm{OH})_{3}(s)+5 \mathrm{H}^{+}
$$

is thermodynamically feasible [ $\log K_{298}=-21.8$; (Fredrickson et al. 2004b)], the kinetics of this homogeneous reaction are rate-limited. In contrast, when Fe(II) is sorbed onto other mineral phases, especially iron oxyhydroxides, surface-mediated heterogeneous catalysis becomes important and reduction of $\mathrm{Tc}(\mathrm{VII})$ to $\mathrm{Tc}(\mathrm{IV})$ takes place rapidly above $\mathrm{pH} 6$ (Peretyazhko et al. 2008a; Peretyazhko et al. 2008b; Zachara et al. 2007).

These data demonstrate that the fate of technetium is intimately tied to the geochemistry of iron and, as we shall see, sulfur. Further, the mobility of technetium is affected by biogenic Fe(II), and not simply on Fe(II) produced in inorganic reactions. Therefore, the geochemical behavior of technetium is governed not so much by the overall redox conditions, but by the availability of reducing agents. 


\subsection{Thermodynamics}

Rard et al. (1999) critically analyzed much of the relevant thermodynamic data for technetium compounds and proposed "best" values for each. Many of these are listed in Table 6.2 below. A fairly complete list of thermodynamic values for the solid technetium compounds can be found in (Kotegov et al. 1968), and these agree substantially with those recommended by Rard et al. (1999). Other values for technetium, plus additional ones for rhenium, are published in Wagman et al. (1982) and are provided in Table 6.2. In addition, Rard (1985) published a critical list of data on ruthenium compounds, whose values can be compared against those of the technetium and rhenium compounds.

The data show that for similar compounds (e.g., $\mathrm{TcS}_{2}, \mathrm{ReS}_{2}$, and $\mathrm{RuS}_{2}$ ), the values are fairly similar. Values for other sets of compounds, such as $\mathrm{TcO}_{2}, \mathrm{ReO}_{2}$, and $\mathrm{RuO}_{2}$, exhibit significant differences. For the hydrated $M \mathrm{O}_{2}(M=\mathrm{Tc}, \mathrm{Re}$, and $\mathrm{Ru})$ compounds, exercise must be cautioned in comparing the correct thermodynamic values. Meyer et al. (1991) found that the average number of water molecules in $\mathrm{TcO}_{2} \cdot n \mathrm{H}_{2} \mathrm{O}$ is 1.6 (but with a rather large standard deviation). Thermodynamic values should only be compared with compounds having the same number of water molecules, so values for $M \mathrm{O}_{2} \cdot 2 \mathrm{H}_{2} \mathrm{O}$ are listed to facilitate comparison. Note that for the technetium compounds, thermodynamic values are not listed for $\mathrm{TcO}_{3}$, for the reason that its existence is in question (see Rard et al. 1999 for further discussion on this topic).

Table 6.2. Values of Standard Enthalpy and Free Energy of Formation and Entropy of the Principle Solids of Technetium, Rhenium, and Ruthenium

\begin{tabular}{cccc}
\hline Compound & $\Delta_{\mathrm{f}} \mathrm{H}^{\circ}(\mathrm{kJ} / \mathrm{mol})$ & $\Delta_{\mathrm{f}} \mathrm{G}^{\circ}(\mathrm{kJ} / \mathrm{mol})$ & $\mathrm{S}^{\circ}(\mathrm{J} / \mathrm{mol} / \mathrm{K})$ \\
\hline $\mathrm{TcO}_{2}$ & $-457.8 \pm 11.7^{(\mathrm{a})}$ & $-401.8 \pm 11.8^{(\mathrm{a})}$ & $50.0 \pm 4^{(\mathrm{a})}$ \\
$\mathrm{TcO}_{2} \cdot 1.6 \mathrm{H}_{2} \mathrm{O}$ & -- & $-758.5 \pm 8.4^{(\mathrm{a})}$ & -- \\
$\mathrm{TcO}_{2} \cdot 2 \mathrm{H}_{2} \mathrm{O}$ & -- & $-837.3^{(\mathrm{b})}$ & -- \\
$\mathrm{Tc}_{2} \mathrm{O}_{7}$ & $-1126.5 \pm 14.9^{(\mathrm{a})}$ & $-950.3 \pm 15.5^{(\mathrm{a})}$ & $192.0 \pm 15^{(\mathrm{a})}$ \\
$\mathrm{Tc}_{2} \mathrm{O}_{7} \cdot \mathrm{H}_{2} \mathrm{O}$ & $-1414.2 \pm 14.9^{(\mathrm{a})}$ & $-1194.3 \pm 15.5^{(\mathrm{a})}$ & $278.9 \pm 72.1^{(\mathrm{a})}$ \\
$\mathrm{HTcO}_{4}$ & $-699.0^{(\mathrm{b})}$ & -- & -- \\
$\mathrm{TcS}_{2}$ & $-223.8 \pm 41.0^{(\mathrm{a})}$ & $-216.1 \pm 42.1^{(\mathrm{a})}$ & $71.1 \pm 31.6^{(\mathrm{a})}$ \\
$\mathrm{Tc}_{2} \mathrm{~S}_{7}$ & $-615.0 \pm 57.4^{(\mathrm{a})}$ & $-580.9 \pm 60.4^{(\mathrm{a})}$ & $175.7 \pm 63.2^{(\mathrm{a})}$ \\
$\mathrm{ReO}_{2}$ & $-610.9^{(\mathrm{b})}$ & $-368^{(\mathrm{b})}$ & -- \\
$\mathrm{ReO}_{2} \cdot 2 \mathrm{H}_{2} \mathrm{O}$ & $-987^{(\mathrm{b})}$ & -- & -- \\
$\mathrm{ReO}_{3}$ & $-605^{(\mathrm{b})}$ & -- & -- \\
$\mathrm{Re}_{2} \mathrm{O}_{7}$ & $-1241.4^{(\mathrm{c})}$ & $-1066.9^{\mathrm{c}}$ & $207.3^{(\mathrm{c})}$ \\
$\mathrm{HReO}_{4}$ & $-762.3^{(\mathrm{b})}$ & $-656.4^{(\mathrm{b})}$ & $158.2^{(\mathrm{b})}$ \\
\hline
\end{tabular}


Table 6.2. (contd)

\begin{tabular}{cccc}
\hline Compound & $\Delta_{\mathrm{f}} \mathrm{H}^{\circ}(\mathrm{kJ} / \mathrm{mol})$ & $\Delta_{\mathrm{f}} \mathrm{G}^{\circ}(\mathrm{kJ} / \mathrm{mol})$ & $\mathrm{S}^{\circ}(\mathrm{J} / \mathrm{mol} / \mathrm{K})$ \\
\hline $\mathrm{ReS}_{2}$ & $-180.0^{(\mathrm{b})}$ & -- & -- \\
$\mathrm{Re}_{2} \mathrm{~S}_{7}$ & $-451.5^{(\mathrm{c})}$ & -- & -- \\
$\mathrm{RuO}_{2}$ & $-307.2 \pm 7.8^{(\mathrm{d})}$ & $-253.1 \pm 8.2^{(\mathrm{d})}$ & $52.28 \pm 7^{(\mathrm{d})}$ \\
$\mathrm{RuO}_{2} \cdot 2 \mathrm{H}_{2} \mathrm{O}$ & -- & $-691.0 \pm 13^{(\mathrm{d})}$ & -- \\
$\mathrm{RuS}_{2}$ & $-199.5 \pm 1.7^{(\mathrm{d})}$ & $-188.4 \pm 1.7^{(\mathrm{d})}$ & $55.2 \pm 1.7^{(\mathrm{d})}$ \\
\hline
\end{tabular}

Sources:
(a) (Rard et al. 1999)
(b) (Wagman et al. 1982)
(c) (Cotton and Wilkinson 1980)
(d) (Rard 1985)

The free energies of formation of the aqueous species of technetium and of $\mathrm{ReO}_{4}{ }^{-}$are listed in Table 6.3. The recommended values of $\Delta_{\mathrm{f}} H^{\circ}, \Delta_{\mathrm{f}} G^{\circ}$ and $S^{\circ}$ for $\mathrm{TcO}_{4}{ }^{-}$are $-729.4 \pm 7.6 \mathrm{~kJ} / \mathrm{mol},-637.4 \pm$ $7.6 \mathrm{~kJ} / \mathrm{mol}$, and $199.6 \pm 1.5 \mathrm{~J} / \mathrm{mol} /{ }^{\circ}$, respectively. Most of the values for technetium come from Rard et al. (1999), but note that several measured or estimated values for carbonate (Lemire and Jobe 1996) and sulfate complexes (Langmuir 1997) are also included. Four mixed hydroxyl-carbonate species are listed that have net charges of neutral to minus three. All of these are Tc(IV) species, except $\mathrm{Tc}(\mathrm{OH})_{2}\left(\mathrm{CO}_{3}\right)_{2}{ }^{3-}$, which contains the Tc(III) cation. From a stability standpoint, it is not clear which of these species will dominate at any particular set of conditions, and the lack of thermodynamic data hampers the evaluation of this problem. Note also that the value of $\Delta_{\mathrm{f}} G^{\circ}$ for $\mathrm{TcOSO}_{4}{ }^{\circ}$ is an estimate (Langmuir 1997); clearly, thermodynamic data for sulfate and sulfide species are needed, especially because of the propensity of technetium and sulfur to bond.

Table 6.3. Free Energies of Formation of Aqueous Technetium Species and the Perrhenate Anion

\begin{tabular}{|c|c|c|}
\hline Aqueous Species & $\Delta_{\mathrm{f}} \mathrm{G}^{\circ}(\mathrm{kcal} / \mathrm{mol})$ & $\Delta_{\mathrm{f}} \mathrm{G}^{\circ}(\mathrm{kJ} / \mathrm{mol})$ \\
\hline $\mathrm{TcO}^{2+}$ & $-24.04^{(\mathrm{a})}$ & $-100.6^{(\mathrm{a})}$ \\
\hline $\mathrm{TcOOH}^{+}$ & $-79.18^{(\mathrm{a})}$ & $-331.3^{(\mathrm{a})}$ \\
\hline $\mathrm{TcO}(\mathrm{OH})_{2}^{\circ}$ & $-132.89^{(a)}$ & $-556.0^{(\mathrm{a})}$ \\
\hline$\left[\mathrm{TcO}(\mathrm{OH})_{2}{ }^{\circ}\right]_{2}$ & $-274.67^{(a)}$ & $-1149.2^{(\mathrm{a})}$ \\
\hline $\mathrm{TcO}_{4}^{-}$ & $-152.34^{(\mathrm{a})}$ & $-637.4^{(\mathrm{a})}$ \\
\hline $\mathrm{TcO}(\mathrm{OH})_{3}^{-}$ & $-174.08^{(b)}$ & $-728.4^{(\mathrm{b})}$ \\
\hline $\mathrm{Tc}(\mathrm{OH})_{2} \mathrm{CO}_{3}{ }^{\circ}$ & $-228.04^{(b)}$ & $-954.1^{(\mathrm{b})}$ \\
\hline $\mathrm{Tc}(\mathrm{OH})_{3} \mathrm{CO}_{3}^{-}$ & $-273.45^{(b)}$ & $-1144.1^{(b)}$ \\
\hline $\mathrm{Tc}(\mathrm{OH})\left(\mathrm{CO}_{3}\right)_{2}^{-}$ & $-324^{(\mathrm{c})}$ & $-1355^{(\mathrm{c})}$ \\
\hline $\mathrm{Tc}(\mathrm{OH})_{2}\left(\mathrm{CO}_{3}\right)_{2}^{3-}$ & $-354^{(\mathrm{c})}$ & $-1483^{(\mathrm{c})}$ \\
\hline $\mathrm{TcOSO}_{4}^{\circ}$ & $-205.27^{(b)}$ & $-858.9^{(b)}$ \\
\hline $\mathrm{ReO}_{4}^{-}$ & $-166.0^{(\mathrm{d})}$ & $-694.5^{(\mathrm{d})}$ \\
\hline
\end{tabular}

Sources:
(a) (Rard et al. 1999)
(c) (Lemire and Jobe 1996)
(b) (Langmuir 1997)
(d) (Wagman et al. 1982) 
To evaluate the similarity in behavior between technetium and its congeners chromium, molybdenum, tungsten, manganese, rhenium, ruthenium, and osmium, Table 6.4 is a compilation of the heats and free energies of formation of a variety of crystalline compounds and aqueous species. Values of $\Delta_{\mathrm{f}} H^{\circ}$ for $\mathrm{CrO}_{2}, \mathrm{WO}_{2}, \mathrm{MoO}_{2}, \mathrm{MnO}_{2}$ and $\mathrm{ReO}_{2}$ are comparable (-610 to $-520 \mathrm{~kJ} / \mathrm{mol}$ ), and the values for $\mathrm{TcO}_{2}$ and $\mathrm{RuO}_{2}$ are slightly lower $(-458$ and $-307 \mathrm{~kJ} / \mathrm{mol})$. These numbers indicate that substitution of between the dioxides should be thermodynamically permissible.

Table 6.4. Standard Enthalpies and Free Energies of Formation of Chromium, Molybdenum, Tungsten, Manganese, Technetium, Rhenium, Ruthenium, and Osmium Compounds (Data from Wagman et al. 1982; Rard 1985)

\begin{tabular}{|c|c|c|c|}
\hline Compound & State & $\Delta_{\mathrm{f}} \mathrm{H}^{\circ}(\mathrm{kJ} / \mathrm{mol})$ & $\Delta_{\mathrm{f}} \mathrm{G}^{\circ}(\mathrm{kJ} / \mathrm{mol})$ \\
\hline $\mathrm{CrO}_{2}$ & $\mathrm{cr}$ & -598 & -- \\
\hline $\mathrm{CrO}_{4}^{2-}$ & $\mathrm{aq}$ & -881.15 & -727.75 \\
\hline $\mathrm{MoO}_{2}$ & $\mathrm{cr}$ & -588.94 & -533.01 \\
\hline $\mathrm{MoO}_{4}{ }^{2-}$ & $\mathrm{aq}$ & -997.9 & -836.3 \\
\hline $\mathrm{MoS}_{2}$ & $\mathrm{cr}$ & -235.1 & -225.9 \\
\hline $\mathrm{WO}_{2}$ & $\mathrm{cr}$ & -589.69 & -533.89 \\
\hline $\mathrm{WO}_{4}^{2-}$ & $\mathrm{aq}$ & -1075.7 & -- \\
\hline $\mathrm{WS}_{2}$ & $\mathrm{cr}$ & -209 & -- \\
\hline $\mathrm{MnO}_{2}$ & $\mathrm{cr}$ & -520.03 & -465.14 \\
\hline $\mathrm{MnO}_{4}^{-}$ & $\mathrm{aq}$ & -541.4 & -447.2 \\
\hline $\mathrm{MnO}_{4}{ }^{2-}$ & $\mathrm{aq}$ & -653 & -500.7 \\
\hline $\mathrm{TcO}_{2}$ & $\mathrm{cr}$ & -457.8 & -401.8 \\
\hline $\mathrm{TcO}_{4}^{-}$ & $\mathrm{aq}$ & -729.4 & -637.4 \\
\hline $\mathrm{TcO}_{4}^{2-}$ & aq & -575.76 & -- \\
\hline $\mathrm{Tc}_{2} \mathrm{O}_{7}$ & $\mathrm{cr}$ & -1414.2 & -1194.3 \\
\hline $\mathrm{TcS}_{2}$ & $\mathrm{cr}$ & -223.8 & -216.1 \\
\hline $\mathrm{Tc}_{2} \mathrm{~S}_{7}$ & $\mathrm{cr}$ & -651.0 & -580.9 \\
\hline $\mathrm{ReO}_{2}$ & $\mathrm{cr}$ & -610.9 & -694.5 \\
\hline $\mathrm{ReO}_{4}^{-}$ & $\mathrm{aq}$ & -787.4 & -694.5 \\
\hline $\mathrm{Re}_{2} \mathrm{O}_{7}$ & $\mathrm{cr}$ & -1241.4 & -1066.9 \\
\hline $\operatorname{ReS}_{2}$ & $\mathrm{cr}$ & -180.0 & -- \\
\hline $\mathrm{Re}_{2} \mathrm{~S}_{7}$ & $\mathrm{cr}$ & -451.5 & -- \\
\hline $\mathrm{RuO}_{2}$ & $\mathrm{cr}$ & -307.2 & -253.1 \\
\hline $\mathrm{RuO}_{4}^{-}$ & $\mathrm{aq}$ & -332.4 & -250.1 \\
\hline $\mathrm{RuO}_{4}^{2-}$ & $\mathrm{aq}$ & -457.0 & -306.6 \\
\hline $\mathrm{RuS}_{2}$ & $\mathrm{cr}$ & -197.0 & -- \\
\hline $\mathrm{OsS}_{2}$ & $\mathrm{cr}$ & -146.0 & -- \\
\hline
\end{tabular}


The solubility of $\mathrm{TcO}_{2} \cdot n \mathrm{H}_{2} \mathrm{O}$, written as:

$$
\mathrm{TcO}_{2} \cdot n \mathrm{H}_{2} \mathrm{O}(s)=\mathrm{TcO}(\mathrm{OH})_{2}{ }^{\circ}+(n-1) \mathrm{H}_{2} \mathrm{O}
$$

has been measured by several investigators (Eriksen et al. 1992; Meyer et al. 1991) and these results have been reviewed by Rard et al. (1999). Some solubility measurements have been hampered by a number of factors. First, measurements must be made in a low-oxygen environment. Experiments that have been carefully performed to minimize the oxygen concentration report relatively low solubilities (Eriksen et al. 1992; Meyer et al. 1991). Second, the effects of radiolysis must be taken into account. For example, (Meyer et al. 1991) found that radiolysis of the water near the surface of the $\mathrm{TcO}_{2} \cdot n \mathrm{H}_{2} \mathrm{O}$ crystals caused oxidation and dissolution of the solid to yield $\mathrm{TcO}_{4}{ }^{-}$. Analyses of the solution by liquid scintillation counting that ignored this quantity of $\mathrm{TcO}_{4}{ }^{-}$would yield spuriously higher solubility values. (Meyer et al. 1991) remedied this by separating $\mathrm{TcO}_{4}{ }^{-}$out of solution using tetraphenylarsonium chloride in chloroform. ${ }^{1}$ Third, the solubility depends on the crystallinity of the $\mathrm{TcO}_{2} \cdot n \mathrm{H}_{2} \mathrm{O}$. Not only does poorly crystalline $\mathrm{TcO}_{2}$ dissolve more rapidly into solution (Lieser et al. 1987), the solubility of amorphous technetium dioxide $\left[\mathrm{TcO}_{2}(\mathrm{am})\right]$ is about a factor of 10 times higher than that of crystalline $\mathrm{TcO}_{2} \cdot n \mathrm{H}_{2} \mathrm{O}$ (Rard et al. 1999). In consideration of these caveats, the accepted value of solubility of $\mathrm{TcO}_{2} \cdot n \mathrm{H}_{2} \mathrm{O}$ at $25^{\circ} \mathrm{C}$ in dilute solutions between $\mathrm{pH} 4$ to $\mathrm{pH} 10$ is $10^{-8.2} \mathrm{~mol} / \mathrm{L}$ (Eriksen et al. 1992) to $10^{-8.44} \mathrm{~mol} / \mathrm{L}$ (Rard et al. 1999), which overlaps in value within experimental uncertainty. This translates into $16,800 \mathrm{pCi} / \mathrm{L}$ $\mathrm{Tc}$ [as $\mathrm{TcO}(\mathrm{OH})_{2}{ }^{\circ}$ in neutral $\mathrm{pH}$ waters] in equilibrium with the hydrated crystalline $\mathrm{TcO}_{2}$ phase, which is about 20 times higher than the drinking water standard (DWS) of $900 \mathrm{pCi} / \mathrm{L}$ established by the EPA. Accordingly, any remediation scheme that relies simply on reduction and precipitation of a $\mathrm{TcO}_{2}$ solid will still result in concentrations of aqueous Tc above the drinking water limit. ${ }^{2}$

At acidic conditions the solubility of $\mathrm{TcO}_{2} \cdot n \mathrm{H}_{2} \mathrm{O}$ increases. Between $\mathrm{pH} 4$ and 0 , the solubility of $\mathrm{TcO}_{2} \cdot n \mathrm{H}_{2} \mathrm{O}$ increases by nearly a factor of $10^{4}$ times. Between $\mathrm{pH} 2.43$ and 1.37 the dominant aqueous species is $\mathrm{TcO}(\mathrm{OH})^{+}$and below $\mathrm{pH} 1.37$ the dominant aqueous species is $\mathrm{TcO}^{2+}$. The solubility (s), hydrolysis (h1 and h2), and dimerization (dim) constants are:

$$
\begin{array}{ll}
\mathrm{TcO}_{2} \cdot n \mathrm{H}_{2} \mathrm{O}+(1-n) \mathrm{H}_{2} \mathrm{O}=\mathrm{TcO}^{2+}+2 \mathrm{OH}^{-} & K_{\mathrm{s}}=4.47 \times 10^{-33} \\
\mathrm{TcO}^{2+}+\mathrm{H}_{2} \mathrm{O}=\mathrm{TcO}(\mathrm{OH})^{+}+\mathrm{H}^{+} & K_{\mathrm{h} 1}=4.3 \times 10^{-2} \\
\mathrm{TcO}(\mathrm{OH})^{+}+\mathrm{H}_{2} \mathrm{O}=\mathrm{TcO}(\mathrm{OH})_{2}{ }^{\circ}+\mathrm{H}^{+} & K_{\mathrm{h} 2}=3.7 \times 10^{-3} \\
2 \mathrm{TcO}(\mathrm{OH})_{2}{ }^{\circ}=\left[\mathrm{TcO}(\mathrm{OH})_{2}\right]_{2}^{\circ} & K_{\mathrm{dim}}=3.14 \times 10^{6}
\end{array}
$$

The average stoichiometery of $n$ in Equation (10), from experiments at both acidic and basic conditions, is $1.63 \pm 0.28$ (Meyer et al. 1991). This value makes handling Equation (10) somewhat clumsy, because the value in the parentheses on the left-hand side $(1-n)$ is less than 1 .

\footnotetext{
${ }^{1}$ The solubility of technetium is greater in solutions with high dielectric constants. In the presence of chloroform, which has a low dielectric constant, technetium partitions into the tetraphenylarsonium chloride (Anders 1960). ${ }^{2}$ In vadose zone sediments, the concentration of ${ }^{99} \mathrm{Tc}$ will indeed be greater than that of the DWS, but the rate of transfer to underlying aquifer may be such that the concentration of ${ }^{99} \mathrm{Tc}$ will be below the DWS.
} 
The solubility of $\mathrm{TcO}_{2} \cdot n \mathrm{H}_{2} \mathrm{O}$ was also determined from neutral to basic conditions by Eriksen et al. (1992). The solubility values determined by these investigators over the same $\mathrm{pH}$ conditions as Meyer et al. (1991) overlap within experimental uncertainty. At pH values between 10 and 12, Eriksen et al. (1992) reported that the solubility of $\mathrm{TcO}_{2} \cdot n \mathrm{H}_{2} \mathrm{O}$ increased by a factor of approximately 10 times. They proposed a general equation to describe the dependency of the solubility on $\mathrm{pH}$ :

$$
[\mathrm{Tc}(\mathrm{IV})]_{\mathrm{tot}}=\mathrm{K}_{\mathrm{s} 1}+\mathrm{K}_{\mathrm{s} 2} /\left[\mathrm{H}^{+}\right]
$$

in which $[\mathrm{Tc}(\mathrm{V})]_{\text {tot }}$ is the total amount of $\mathrm{Tc}(\mathrm{IV})$ species and $\log K_{\mathrm{s} 1}$ and $\log K_{\mathrm{s} 2}$ have the respective values of $-8.16 \pm 0.06$ and $-19.2 \pm 0.3$. The authors also carried out experiments in which $\mathrm{CO}_{2}$ was added. The effect of $\mathrm{CO}_{2}$ is to increase the solubility of $\mathrm{TcO}_{2} \cdot n \mathrm{H}_{2} \mathrm{O}$. When the $p \mathrm{CO}_{2}$ was increased from 0 to 50 percent the solubility increased by nearly 10 times. Eriksen et al. (1992) report the following equilibrium constants between $\mathrm{TcO}_{2} \cdot n \mathrm{H}_{2} \mathrm{O}, \mathrm{CO}_{2}, \mathrm{H}_{2} \mathrm{O}$ and hydroxo and hydroxo-carbonato complexes:

$$
\begin{array}{ll}
\mathrm{TcO}_{2} \cdot n \mathrm{H}_{2} \mathrm{O}=\mathrm{TcO}(\mathrm{OH})_{2}{ }^{\circ}+(n-1) \mathrm{H}_{2} \mathrm{O} & K_{\mathrm{s}}=6.76 \times 10^{-9} \\
\mathrm{TcO}_{2} \cdot n \mathrm{H}_{2} \mathrm{O}+\mathrm{H}_{2} \mathrm{O}=\mathrm{TcO}(\mathrm{OH})_{3}{ }^{-}+\mathrm{H}^{+}+(n-2) \mathrm{H}_{2} \mathrm{O} & K_{\mathrm{s} 2}=8.71 \times 10^{-20} \\
\mathrm{TcO}_{2} \cdot n \mathrm{H}_{2} \mathrm{O}+\mathrm{CO}_{2}=\mathrm{Tc}(\mathrm{OH})_{2} \mathrm{CO}_{3}{ }^{\circ}+(n-1) \mathrm{H}_{2} \mathrm{O} & K_{\mathrm{s} 3}=8.13 \times 10^{-8} \\
\mathrm{TcO}_{2} \cdot n \mathrm{H}_{2} \mathrm{O}+\mathrm{CO}_{2}+\mathrm{H}_{2} \mathrm{O}=\mathrm{Tc}(\mathrm{OH})_{3} \mathrm{CO}_{3}{ }^{-}+\mathrm{H}^{+}+(n-2) \mathrm{H}_{2} \mathrm{O} & K_{\mathrm{s} 4}=4.47 \times 10^{-16}
\end{array}
$$

Although Meyer et al. (1991) did not find evidence for an increase in solubility because of the presence of chloride in solution, Hess et al. (2004) concluded otherwise. These latter investigators showed that in chloride solutions of $1 \times 10^{-3}$ to $5 \mathrm{M} \mathrm{NaCl}$, technetium likely forms $\mathrm{TcCl}_{6}{ }^{2-}$ and $\mathrm{TcCl}_{4}{ }^{\circ}(\mathrm{aq})$ complexes. An increase in the solubility of technetium was also reported by Lieser et al. (1987), although only at relatively low pH values. In general, the data of Hess et al. (2004) are consistent with those of Lieser et al. (1987).

\subsection{Sorption}

Sorption relates the quantity of a chemical species associated with solid components of soil to the concentration in the contacting solution. Partitioning between solids and solution is generally assumed to take place under equilibrium conditions and is dependent on the solution composition ( $\mathrm{pH}$, concentration of competing ions) and soil characteristics (point-of-zero-charge, surface area). Partitioning is typically expressed as the distribution coefficient, $K_{\mathrm{D}}$ :

$$
K_{\mathrm{D}}=\left[\left(\mathrm{C}_{\text {initial }}-\mathrm{C}_{\text {final }}\right) \mathrm{V}_{\text {initial }} / \mathrm{M}_{\text {sed }}\right] / \mathrm{C}_{\text {final }}
$$

in which $\mathrm{C}_{\text {initial }}$ is the beginning concentration of technetium in solution, $\mathrm{C}_{\text {final }}$ is the concentration of technetium at the end of the experiment, $\mathrm{V}_{\text {initial }}$ is the beginning volume of water before soil is added, and $\mathrm{M}_{\text {sed }}$ is the mass of sediment added. Although interaction of the ion with the solid is assumed to be surface sorption, there are a number of cases, especially when the concentration of the species is relatively high, when precipitation occurs on the mineral surface. Accordingly, sorption should be regarded as an empirical value rather than a mechanistic description. Because technetium is also redox sensitive, its partitioning behavior will also depend on the $E_{\mathrm{h}}$ of the system and the presence of materials that lead to 
reduction, such as organic matter. As previously discussed, the reduction of $\mathrm{Tc}(\mathrm{VII})$ to $\mathrm{Tc}(\mathrm{IV})$ takes place between 200 and $100 \mathrm{mV}$ over circum-neutral pH values (Lieser and Bauscher 1987).

Partitioning behavior is starkly different for Tc(VII) and Tc(IV). As amplified more fully below, pertechnetate sorbs poorly onto typical soil materials whereas $\mathrm{Tc}(\mathrm{IV})$ sorbs reasonably well onto a variety of materials. If $\mathrm{Tc}(\mathrm{VII})$ could be reduced to Tc(IV), the sorption (mostly irreversible) will increase by a factor of $10^{3}$ (Lieser and Bauscher 1987). Further, Tc(IV) is also prone to sorb onto $\mathrm{FeS}_{2}$ (Bruggeman et al. 2007), although it is not clear if the sorbed technetium forms a Tc-S bond. Because most aquifers are assumed to be in contact with the atmosphere, and because most arable soils display $E_{\mathrm{h}}$ values in the mildly oxidizing to oxidizing range (Koch-Steindl and Pröhl 2001), most partitioning experiments are conducted under aerobic conditions. These experimental conditions seem justified because of the observed fast transit ( 90 percent of the groundwater velocity) of technetium in aquifers (Rudin et al. 1992).

Results of partitioning experiments have demonstrated that pertechnetate sorbs weakly onto solid phases. Wildung et al. (1974) for example, reported that 22 different soils were equilibrated with pertechnetate for 24 hours and yielded $K_{\mathrm{D}}$ values (pCi sorbed per g soil/pCi solute per $\mathrm{mL}$ solution) of 0.007 to $2.8 \mathrm{~mL} / \mathrm{g}$. Subsequent studies have yielded similar results. Sheppard and Sheppard (1984) reported small values of $K_{\mathrm{D}}(<0.005 \mathrm{~mL} / \mathrm{g})$ measured on soils using lysimeters. These results reflect the electrostatic repulsion between the negatively charged pertechnetate anion $\left(\mathrm{TcO}_{4}{ }^{-}\right)$and the negative surface charge carried by sedimentary materials in temperate climates at near-neutral $\mathrm{pH}$ values. Kaplan and Serne (1998) reported small positive to negative $K_{\mathrm{D}}$ values $(-0.16$ to $+0.11 \mathrm{~mL} / \mathrm{g})$ for soils sampled from the Hanford Site, Washington State. Negative $K_{\mathrm{D}}$ values are possible because of the principle of excluded water. Water molecules will orient themselves with the positive end of their dipole towards the negatively charged mineral surface and, depending on the properties of the metal—oxygen surface species and ambient solution $\mathrm{pH}$, a zone of structured water develops that repels negatively charged species, such as pertechnetate. Solution extracted from the experiment will typically not include the water sorbed at the surface of the mineral grains, so the pertechnetate is concentrated in the sampled "excluded" bulk solution. Thus, the concentration of pertechnetate in the final compared to the beginning solution may be higher, yielding negative $K_{\mathrm{D}}$ values (see Equation 19).

In an attempt to determine the controls on pertechnetate partitioning Wildung et al. (1984) carried out longer-termed experiments (1050 hours) on 30 different soils representing a wide range in climate, composition (including high- and low-carbon soils), and physical properties (such as surface area). Sorption of pertechnetate was correlated with particle size distribution, major element composition, mineralogy, the presence of amorphous iron, aluminum, silicon, and manganese, and solution properties such as $E_{\mathrm{h}}, \mathrm{pH}$, organic carbon and nitrogen. The reservoirs of extractable metals, such as aluminum and iron, were quantified by use of selective solution extractions (SSE) while organic carbon was extracted using hydrogen peroxide. They observed that $K_{\mathrm{D}}$ values $(<1$ to 12.7 for grassland-shrub and 8.3 to 46.6 for forest-marshland soils) were related to both organic carbon and nitrogen, especially over long experimental durations. Over the same time interval (1050 hours), technetium sorption also correlated well with extractable iron (using ammonium oxalate) and fine to coarse clay. Over shorter periods of time (48 hours), technetium sorption correlated well with organic carbon, nitrogen, extractable iron (using either ammonium oxalate or citrate-bicarbonate- dithionite solutions), extractable aluminum, and coarse clay. Values of $K_{\mathrm{D}}$ obtained from shorter duration experiments are lower (less than 1 to 5.7 for grasslandshrub and 5.1 to 31.0 for forest-marshland soils) than that of longer-duration experiments, indicating some form of early kinetic control. In both short- and long-term experiments technetium sorption was 
negatively correlated with $\mathrm{pH}$. These trends were especially pronounced in forest-marshland compared to grassland-shrub soils. Their overall conclusion was that technetium sorption is very limited, even in soils that contain a large amount of organic carbon and nitrogen.

Note, however, that use of $\mathrm{H}_{2} \mathrm{O}_{2}$ to remove organic carbon from a soil sample can potentially produce experimental artifacts. A number of investigators (Geraedts et al. 2002; Stalmans et al. 1986; Van Loon et al. 1986; Wolfrumm and Bunzl 1986) have reported a strong affinity between technetium and organic matter, with relatively high $K_{\mathrm{D}}$ values (see Section 6.5). In these soils, it appears that technetium is reduced in the presence of organic matter, and exposure to $\mathrm{H}_{2} \mathrm{O}_{2}$ results in rapid oxidation of technetium to pertechnetate. Therefore, $K_{\mathrm{D}}$ values for technetium in organic-rich soils may be higher than extraction using $\mathrm{H}_{2} \mathrm{O}_{2}$ would indicate.

It is important to point out that the small $K_{\mathrm{D}}$ values reported by geochemists seem to be contradicted by the results obtained from soil scientists. Despite the relatively oxidizing conditions of most farm lands, technetium appears to be bound up in soil, especially in periodically wet conditions (Ishii et al. 2004a; Ishii et al. 2004b; Tagami and Uchida 1997; Tagami and Uchida 1999). The relative immobility of technetium in agricultural fields was first noticed by Henrot (1989), who proposed that microbial activity may be causing reduction with consequent sorption and precipitation in the soil. In this model microbial activity in the soil causes depletion of oxygen in the interstices of mineral grains, and diffusion of $\mathrm{O}_{2}$ through a layer of water becomes rate-limiting. Therefore, technetium immobility may occur, even in soils in which oxidizing conditions are assumed.

Because of the low solubility of $\mathrm{TcO}_{2}(\mathrm{am})$ and $\mathrm{TcO}_{2} \cdot n \mathrm{H}_{2} \mathrm{O}(\mathrm{cr})$ compounds, experiments carried out under reducing conditions typically contain technetium concentrations that exceed the solubility limit. Lower technetium concentrations could be used, but this imposes nearly insurmountable analytical challenges to experiments, typically precluding this option. For example, Baston et al. (2002) described the behavior of technetium in an experimental apparatus that mimics the conditions expected for technetium disposal in Boom Clay. The Boom Clay system is naturally reducing and pore water, presumably in equilibrium with it, contains high concentrations of organic matter as well. The $\mathrm{pH}$ of the system is near neutral (approximately 8 ) and the $E_{\mathrm{h}}$ value was measured at $-230 \mathrm{mV}$, well below the threshold of Tc(VII) reduction. Introduction of pertechnetate to the system resulted in reduction and immobilization of technetium, probably through precipitation. The absence of organic matter, accomplished through filtration at $30000 \mathrm{MWCO}^{1}$, did not appear to affect the solubility or sorption of technetium. Migration experiments yielded calculated $K_{\mathrm{D}}$ values of 0.8 to $1.8 \mathrm{~mL} / \mathrm{g}$, which are larger than the values typically reported in pertechnetate sorption studies. Larger $K_{\mathrm{D}}$ values are not expected because the likely species at this $\mathrm{pH}$ value is $\mathrm{TcO}(\mathrm{IV})(\mathrm{OH})_{2}{ }^{\circ}$, which probably has a low sorption potential.

The same patterns of technetium distribution emerge from studies of marine sediments and suspended particulate matter. In near-surface waters, conditions are oxidizing and technetium is in the pertechnetate form. Distribution coefficients of less than $1 \mathrm{~mL} / \mathrm{g}$ have been reported for pertechnetate distribution in seawater and suspended particles (McCubbin et al. 2006). On the other hand, much higher $K_{\mathrm{D}}$ values were reported for sorption of technetium in reduced marine environments. Typical $K_{\mathrm{D}}$ values for technetium partitioning between marine sediments and seawater are between $10^{2}$ and $10^{3}$ (Harvey and Kershaw 1984; IAEA 2004). For example, McCubbin et al. (2006) reported $K_{\mathrm{D}}$ values between approximately $3 \times 10^{2}$ and approximately $5 \times 10^{3} \mathrm{~mL} / \mathrm{g}$ for sediments from the Irish Sea sampled between

\footnotetext{
${ }^{1} \mathrm{MWCO}=$ molecular weight cut-off. The $30000 \mathrm{MWCO}$ is approximately equivalent to $0.22 \mu \mathrm{m}$ pore filter.
} 
1995 and 2002. However, the measured $K_{\mathrm{D}}$ values were calculated based on technetium concentrations in seawater, and not from pore water in contact with the sediments. The authors also point out that their $K_{\mathrm{D}}$ values are about an order of magnitude larger than those obtained from experiments. They attribute this discrepancy to non-equilibrium binding between sedimentary particles and technetium in seawater, with the implication that $K_{\mathrm{D}}$ values are kinetically governed.

In contrast to the simple pattern of technetium distribution discussed above, there are several cases where technetium behavior is not consistent with that expected. Zhang et al. (2000) conducted a series of tests over an interval of $\mathrm{pH}$ (5 to 9.6), aqueous nitrate ( 0.0005 to $0.10 \mathrm{M})$, and aluminum-bearing solids (boehmite, Al-oxyhydroxide gels, and simulated tank wastes) in order to measure the partitioning of rhenium and technetium between solids and solution. Concentrations of perrhenate were generally $5 \times 10^{-4} \mathrm{~mol} / \mathrm{L}$ (which is higher than the concentrations of technetium typically found in waste streams). Measured $K_{\mathrm{D}}$ values vary from 5 to $105 \mathrm{~mL} / \mathrm{g}$, depending on nitrate concentration, solution $\mathrm{pH}$, and identity of the solid. In boehmite $[\mathrm{AlO}(\mathrm{OH})]$ suspensions, the highest $K_{\mathrm{D}}$ values were measured in $\mathrm{pH}=5$ solutions with low nitrate concentrations. Competition between nitrate and perrhenate sorption was fairly strong; increasing activities of nitrate caused a decrease in perrhenate sorption, but in a non-linear fashion (higher activities of nitrate had a relatively small effect on $K_{\mathrm{D}}$ values). High $K_{\mathrm{D}}$ values were also found for aluminum-rich gels $(21$ to $111 \mathrm{~mL} / \mathrm{g})$. This might be an important scenario for tanks leaking into the environment; the alkaline solutions may partially dissolve aluminum-bearing phases resulting in the formation of amorphous Al-oxyhydroxides that sequester technetium. Experiments were also undertaken in which technetium, rather than rhenium, was used to confirm the results of tests with perrhenate. Additional tests were conducted with $\mathrm{SeO}_{4}{ }^{2-}, \mathrm{ReO}_{4}{ }^{-}$and $\mathrm{TcO}_{4}{ }^{-}$with a variety of stimulant tank sludge materials that possessed chemical similarity to various sludge materials produced using the five waste streams (Bi-phosphate, U-recovery, REDOX, PUREX-Al clad, and PUREX-Zr clad). Sorption of these anions was highest in sludge simulants that contained the highest concentrations of aluminum. X-ray diffraction confirmed that boehmite was the main phase in the high-aluminum sludge.

\subsection{Colloids}

In experiments with high concentrations of technetium (greater than $10^{-5} \mathrm{M} \mathrm{Tc}$ ), several investigators have reported formation of colloids of technetium at moderately acidic $(\mathrm{pH} \leq 4)$ (Lieser et al. 1987; Sekine et al. 2004; Vichot et al. 2002) and under reducing conditions (Sekine et al. 2002). They report brown to brownish-black turgid solutions that are consistent with the presence of colloids. Congeners of technetium, such as rhenium and ruthenium, are also known to form collections or clusters of molecules at the same scale of colloids, but technetium does not display this tendency to the magnitude that ruthenium does (Rard 1985). At the same time, it is well-known that dimers of technetium, such as $\left[\mathrm{TcO}(\mathrm{OH})_{2}\right]_{2}$, can form and other types of dimers $\left[\left(\mathrm{H}_{2} \mathrm{EDTA}\right)_{2} \mathrm{Tc}_{2}(\mu-\mathrm{O})_{2}\right]$ can be synthesized in the presence of EDTA (Bürgi et al. 1981). In the latter case, technetium in octahedral coordination connects to other octahedrons through double bridging between two ligands (i.e., edge-sharing polyhedra), rather than by direct metal - metal bonding. Sekine et al. $(2002,2004)$ also showed that colloids of technetium will form from pertechnetate solutions exposed to radiolysis at acid to near-neutral $\mathrm{pH}$ values. Radiolysis caused reduction of Tc(VII) and formation of Tc(IV) polymers and colloids, first as Tc(IV), then as $\mathrm{TcO}_{2} \cdot n \mathrm{H}_{2} \mathrm{O}$ nanoparticles as the solution $\mathrm{pH}$ increased. Lukens et al. (2002) also showed that radiolysis of pertechnetate solutions can produce polymers similar to the $\left(\mathrm{H}_{2} \mathrm{EDTA}\right)_{2} \mathrm{Tc}_{2}(\mu-\mathrm{O})_{2}$ structure, but in alkaline solutions. In this case, the solutions contained citrate, dibutyl phosphate, and aminopolycarboxylates, similar to some of the organic materials in Hanford waste storage tanks. X-ray 
absorption spectroscopy of the run products showed that the objects consisted of one-dimensional chains with bridging $\mathrm{O}$ atoms shared between two metal centers and water ligands in the trans position. Because of the tendency for colloids of technetium to form at concentrations above saturation, it is best to approach solubility measurements from undersaturated conditions.

The influence of colloids on the geochemical behavior of technetium was explored through a set of experiments performed by Maes et al. (2004). The authors imposed reducing conditions on a groundwater solution spiked with pertechnetate and the resulting solution was equilibrated with natural (Gorleben) sand. Technetium was rapidly reduced with some Tc(IV) sorbing onto magnetite or pyrite grains. Interestingly, the concentration of technetium in solution was much higher than expected and the authors attributed this to the presence of humic substances that increased the solubility of technetium. A set of experiments without the organic-rich Gorleben sand, but carried out in synthetic systems containing magnetite and pyrite, revealed slow reduction kinetics, with more than 200 days required before significant reduction occurred. XANES indicated that nearly all the technetium was in the Tc(IV) state. The technetium atoms were coordinated by 6.1 to 7.2 oxygen atoms at a distance of 2.01 to $2.03 \AA$, as determined by EXAFS methods. These data are consistent with $\mathrm{TcO}_{2}$-like structures (Wharton et al. 2000), including polymeric Tc(IV) species. Evidence for Tc $-\mathrm{S}$ and $\mathrm{Tc}-\mathrm{C}$ bonding were sought for, but were not found.

The lack of data for direct $\mathrm{Tc}-\mathrm{C}$ bonding is somewhat surprising because of the preponderance of organometallic species reported in the literature. However, it is equally likely that technetium imitates the behavior of uranium in that reduction occurs in the presence of organic matter, but no bonds form between uranium and carbon. Sites on organic matter that can be used to transfer electrons for reduction may be abundant, but reduction does not accompany a shift between $\mathrm{Tc}-\mathrm{O}$ and $\mathrm{Tc}-\mathrm{C}$ bonds. The link between technetium and organic material is a complex problem, and is examined in more detail below.

\subsection{Interaction with Humic Substances}

In the natural environment, there appears to be a modicum of evidence for interaction between technetium and organic matter. For example, in the marine environment, seawater containing high concentrations of organic matter (typically at depths well below the oxygen-rich surface waters) yields high partition coefficients ( $K_{\mathrm{D}}$ up to $1500 \mathrm{~mL} / \mathrm{g}$ ) (Brown et al. 1999). In terrestrial environments, a number of investigators have reported retention of technetium in soils containing relatively high amounts of organic matter (Bors et al. 1999; Geraedts et al. 2002; Wolfrumm and Bunzl 1986). In addition, soil scientists have noted that the bioavailability of technetium in plants diminishes with time (Cataldo et al. 1989; Echevarria et al. 1997), and some investigators have speculated that binding between organic matter and technetium may be one reason for the diminishing uptake of technetium into plants with time (Stalmans et al. 1986).

The availability of technetium for uptake into biological systems will depend in large part on the chemical form of technetium [i.e., Tc(VII) vs. Tc(IV)]. For example, Stalmans et al. (1986) argued that organic matter provides an important sink for technetium in soils and sediments and this interaction is strong enough to diminish or prevent uptake by plants. In their experiments immobilization of technetium by organic matter appears to be very strong; addition of complexing agents, such as EDTA, causes little re-solubilization of technetium. However, this argument rests on the assumption that there is significant interaction between EDTA and technetium (see discussion of experiments by 
Maset et al. 2006). They note that particularly strong bonds between technetium and humic acids occur on hydroxyl sites that are adjacent to carboxylic groups. It was not clear from this study, however, if the presence of humic acids provided an environment in which reoxidation and resolubilization was resisted, or if technetium was expressed as a $\mathrm{TcO}_{2}$ precipitate. In experiments in which concentrations of technetium are relatively high ( $\mathrm{mM}$ Tc concentrations) formation of $\mathrm{TcO}_{2}$ precipitates may occur, but this is unlikely to mimic the majority of settings where technetium contamination has occurred $(\mu \mathrm{M} \mathrm{Tc}$ concentrations).

An example of this is provided by the experiments conducted by Maes et al. (2004), who showed that in systems containing high concentrations of dissolved organic matter and high concentrations of technetium $\left(2.2 \times 10^{-3} \mathrm{M}\right)$, reduction and consequent immobilization of technetium occurs. Analyses by EXAFS revealed that the reduced technetium was in the form of a hydrated $\mathrm{TcO}(\mathrm{IV})_{2} \cdot n \mathrm{H}_{2} \mathrm{O}$ solid, most likely expressed as a colloid or polymer rather than a crystal. The data showed no evidence for a carbon backscatterer near the technetium center, so it appears that $\mathrm{Tc}-\mathrm{C}$ bonds were not formed. The relatively high concentrations (approximately $10^{-3} \mathrm{M}$ in experiments versus $10^{-8}$ to $10^{-9} \mathrm{M}$ in contaminated systems) render these conclusions ambiguous, however.

Van Loon et al. (1984), in contradiction to the conclusions of Maes et al. (2004), argued for direct bonding between technetium and organic matter. In their model formation of organometallic technetium is generally a two-step process: formation of complex with labile ligands [such as $\mathrm{K}_{2} \mathrm{TcBr}_{6}$ in their experiments] and by then by reduction in the presence of complexing agents (some material, like cysteine, both reduces and complexes with technetium). In general, binding between technetium and organic matter occurs when there are combinations of two functional groups. Typical functional groups include:

- Hydroxycarboxylates (citrate, malate, tartrate, gluconate, $\beta$-hydroxyisobutyrate).

- Aminocarboxylates (EDTA, DTPA, NTA [nitrilotriacetic acid], etc.).

- Polyamines (ethylenediamine, tri-, tetra- and pentamines, and cyclam [1,5,8,12-tetra-azocyclotetradecane]).

- Sulfydryl amino acids (methionine, cysteine and their derivatives, such as N-acetylcysteine, penicillamine, cysteine-ethylester).

Other functional groups, such as di- and tri-carboxylic acids cannot stabilize reduced technetium "unless at least one adjacent hydroxyl group is present." (Van Loon et al. 1986) These functional groups, or ones like them, are present in large amounts in soil organic matter, and typically in sterically favorable positions, yet an unambiguous, direct linkage between technetium and organic groups has not been presented.

In contrast, other investigators have not found a strong link between technetium immobilization and organic matter in soil. For example, Kaplan (2003) conducted an experimental study to determine the $\mathrm{pH}$-dependent $K_{\mathrm{D}}$ values of technetium and iodine on two different soils, one a wetland sample with relatively high organic matter content, the other an upland soil with virtually no organic matter, but with significant Fe-, Al-coatings on primary mineral grains. However, even the soil samples with relatively high organic matter contents displayed very low Tc $K_{\mathrm{D}}$ values, and within error of those reported for soils lacking organic matter. 
Further support for a limited role between organic matter and technetium (or its analogue, rhenium) was reported in experiments by Kim et al. (2004) and Maset et al. (2006). Kim et al. (2004) reported the results of sorption tests in which organic materials containing either carboxyl (- $\mathrm{COOH})$, sulfonate $\left(-\mathrm{SO}_{3} \mathrm{H}\right)$ or amine $\left(-\mathrm{NH}_{2}\right)$ groups were exposed to solutions containing aqueous perrhenate. They found that only protonated amine groups $\left(\mathrm{NH}_{3}{ }^{+}\right)$were reactive towards perrhenate. Results of experiments in which EDTA, NTA or isosaccharinic acid (ISA) were added to systems in which $\mathrm{TcO}_{4}{ }^{-}$or $\mathrm{ReO}_{4}{ }^{-}$were reduced were reported by Maset et al. (2006). They found that even in soils that contained 12 percent organic carbon that the solubility of Tc(IV) in solution was unaffected. The lack of any observed effect by EDTA on solubility weakens the argument presented by Stalmans et al. (1986), in which a lack of interaction between technetium and EDTA was cited as evidence for strong Tc-OM interactions (see above). Gu and Ruan (2007), on the other hand, reported limited complexation between Tc(IV) and EDTA or humic acids using a Surface-Enhanced Raman Spectroscopy (SERS) technique. Low concentrations of Tc(IV)(aq) can be detected by Raman spectroscopy when technetium sorbs onto nanoparticles of gold that have surfaces modified with positively charged dimethylamine functional groups. The gold particles enhance the Raman signal such that concentrations as low as $10^{-7} \mathrm{M}$ technetium can be detected and the valence state determined. These investigators found that complexation occurred, but when exposed to an oxidizing environment, the Tc(IV) was readily oxidized. The preponderance of evidence suggests, therefore, that strong interactions between technetium and organic matter either do not occur, or are very sensitive to the presence of oxygen. In very unusual chemical environments, such as those represented by tank waste, stronger interaction may occur, as demonstrated by Xia et al. (2006). They found that strong Tc-oxalate complexes formed in solutions with high ionic strength.

Collectively, the data cited above can be interpreted to show that $\mathrm{Tc}-\mathrm{OM}$ interactions occur when concentrations of the organic ligand are above a threshold value. For the concentrations of technetium typically found in pore water solutions, this appears to be a condition that is not typically met. At higher technetium concentrations, technetium is immobilized as a $\mathrm{TcO}_{2}$-like compound, rather than as an element chelated by organic functional groups. In any event, the data indicate that even if complexation occurs, re-oxidation takes place rapidly and cannot be counted on to immobilize technetium for long. In summary, the results indicate that another mechanism takes place to cause reduction of technetium and a likely candidate is discussed in the section on biogeochemistry. 


\subsection{Potential for Remobilization}

As the preceding section illustrates, reduction of technetium may be ephemeral when technetiumbearing sediments, soils, or solutions become exposed to oxidizing conditions or to agents that catalyze oxidation. Addressing the issue of re-oxidation and remobilization of technetium is extremely pertinent for understanding the mobility of technetium between sources and sinks in the natural environment. In the study cited above, Van Loon et al. (1984) reported experimental evidence that suggested rapid reoxidation of reduced forms of technetium. Subsequent studies, however, paint a more complex picture with some studies indicating slow or fast re-oxidation or rates in between. Remobilization of reduced technetium during re-oxidation events has been addressed by Ashworth and Shaw (2005), Begg et al. (2007), Burke et al. (2005, 2006), Morris et al. (2000, 2008). The main theme of these papers is that technetium fate is intimately related to iron and sulfur geochemistry and these, in turn, are strongly governed by microbiological processes.

Estuarine sediments, along with their indigenous microbial population, were amended with $\mathrm{Tc}(\mathrm{VII})$ after progressive anoxia had developed (Burke et al. 2005). Anoxia occurred through stimulation of the nitrate-, iron- and sulfur-reducing microbes in the sediments. Control experiments in which the sediments were sterilized showed that $\mathrm{Tc}(\mathrm{VII})$ reduction did not occur, strongly implicating the role of microorganisms on the valence state of technetium. Although a detailed reckoning of the microbial population was not carried out, populations of nitrate-, iron-, and sulfate-reducing bacteria were separated and sterilized sediments were inoculated with the various microbes. These investigators found that $\mathrm{Tc}(\mathrm{VII})$ reduction occurred when iron- and/or sulfate-reducing bacteria were present, but not when nitrate-reducing bacteria alone were present. Data obtained by x-ray absorption spectroscopy (XAS) reveal that the reduced technetium is manifested as hydrous $\mathrm{Tc}(\mathrm{IV}) \mathrm{O}_{2}$ solids. Some $\mathrm{Fe}(\mathrm{II})$ was present from the initial materials, mostly as Fe(II) in solution. Control experiments indicated that $\mathrm{Fe}$ (II) concentrations in the initial solutions had no effect on $\mathrm{Tc}$ (VII) reduction, indicating that biogenic Fe(II) is somehow more effective as a reducing agent than inorganically-generated $\mathrm{Fe}(\mathrm{II})$.

In a subsequent study Burke et al. (2006) carried out similar experiments in which the indigenous population of microbes in sediments was stimulated so that progressive anoxia occurred. The soils were then amended with $\mathrm{Tc}(\mathrm{VII})$ and the concentrations and valence states of Tc, Fe and $\mathrm{S}$ were determined and $E_{\mathrm{h}}$ monitored. The run products were then exposed to a variety of oxidizing conditions and the remobilization of Tc assessed. During progressive anoxia, Fe(II) and sulfide began to build up in the sediments. As in the previous experiments, nearly all of the Tc(VII) was rapidly reduced and disappeared from solution during iron and sulfate reduction. In sterilized control experiments, $\mathrm{Tc}$ (VII) reduction did not occur.

In re-oxidation experiments, the remobilization of technetium was dependent upon the oxidant. For $\mathrm{O}_{2}$ as the oxidant, about 50 percent of the technetium was remobilized as pertechnetate (Burke et al. 2006). Rapid re-mobilization of technetium (in approximately 66 days) occurred in both the Fe(III) and sulfate-reducing sediments, but the balance of technetium (35 to 45 percent) remained recalcitrant. During $\mathrm{O}_{2}$ re-oxidation, both $E_{\mathrm{h}}$ and Tc in solution increased while $\mathrm{Fe}(\mathrm{II})$ decreased. In general, iron was oxidized faster than technetium. Similar to the Fe-oxidation behavior the sulfate-reducing experiments showed that a fraction of the sulfur was rapidly oxidized, but the balance remained reduced beyond the two months of the experiment's duration. According to the authors, the presence of recalcitrant sulfur even in oxidizing experiments has been previously recorded and may help explain the stabilization of 
heavy metal and radionuclide elements. Thus, the lack of correlation between sulfate and technetium oxidation and re-mobilization, coupled with the XAFS results, which did not show evidence for Tc-S bonding, indicate that sulfide stabilization of technetium is not occurring.

In contrast to $\mathrm{O}_{2}$, when nitrate was used as the oxidant, less than 10 percent of the technetium was remobilized, even though extensive Fe(II) and sulfide re-oxidation occurred. The authors speculate that sulfide and $\mathrm{Fe}$ (III) re-oxidation results from a nitrate-mediated bio-oxidation process that does not affect technetium. They suggest a two-stage process:

$$
\begin{gathered}
\mathrm{FeS}+\mathrm{NO}_{3}{ }^{-}+\mathrm{H}_{2} \mathrm{O} \rightarrow \mathrm{SO}_{4}{ }^{2-}+\mathrm{Fe}^{2+}+\mathrm{NH}_{4}^{+}+2 \mathrm{OH}^{-} \\
2 \mathrm{Fe}^{2+}+\mathrm{NO}_{3}{ }^{-}+\mathrm{H}_{2} \mathrm{O} \rightarrow 2 \mathrm{Fe}^{3+}+\mathrm{NO}_{2}^{-}+2 \mathrm{OH}^{-}
\end{gathered}
$$

In other words, iron oxidation is de-coupled from technetium oxidation because of nitrogen reduction. The stoichiometry of products $\left(\mathrm{SO}_{4}{ }^{2-} / \mathrm{NH}_{4}{ }^{+} ; \mathrm{Fe}^{2+} / \mathrm{NO}_{2}{ }^{-}\right)$evolved during the experiments appears to support the argument.

A significant finding of this study was that the $E_{\mathrm{h}}$ of the re-oxidized system rose to $+150 \mathrm{mV}$, which would lead to re-oxidation of technetium, yet very little of the total technetium budget was remobilized. This is evidence that supports the idea that the $E_{\mathrm{h}}$ of the system is less important than the availability of oxidizing or reducing agents. Slow re-oxidation of technetium has been reported elsewhere (Cui and Eriksen 1996a; Standring et al. 2002; Wharton et al. 2000), but the present authors conclude that reoxidation, at least a fraction of it, occurs rapidly. Accordingly, exposure to air results in oxidation of some of the technetium, some of which is mobile, but there is also a fairly large fraction of technetium that remains unaffected by oxidation and is immobile.

Morris et al. (2000), conducted an investigation to trace the distribution of radionuclide elements $\left({ }^{99} \mathrm{Tc} 1{ }^{37} \mathrm{Cs},{ }^{237} \mathrm{~Np},{ }^{238} \mathrm{Pu},{ }^{239} \mathrm{Pu},{ }^{240} \mathrm{Pu},{ }^{239+240} \mathrm{Pu}\right.$, and $\left.{ }^{241} \mathrm{Am}\right)$ in intra-tidal marsh sediments from the Irish Sea. The radionuclide elements were released to seawater from the Sellafield reprocessing plant, in the United Kingdom. The study examined how radionuclide elements became sorbed to small-size particulate matter suspended in the ocean and how the elements became redistributed after deposition.

The contemporary model for radionuclide element distribution is that fine sediments have higher $K_{\mathrm{D}}$ values than coarse sediments. Even so, $K_{\mathrm{D}}$ values for ${ }^{99} \mathrm{Tc}$ are low compared to other elements. For example, the $K_{\mathrm{D}}$ values for transuranic elements are between $10^{4}$ to $10^{6} \mathrm{~mL} / \mathrm{g}$, and $10^{3} \mathrm{~mL} / \mathrm{g}$ for ${ }^{137} \mathrm{Cs}$, but are less than $10 \mathrm{~mL} / \mathrm{g}$ for ${ }^{99} \mathrm{Tc}$. Even though the $K_{\mathrm{D}}$ value for ${ }^{99} \mathrm{Tc}$ is smaller than for other radionuclide elements, there is a substantial degree of particle association because of the high concentration of suspended solids in the water column. Part of the data in this study, therefore, pertains to the control of the mobility of technetium as a function of particle size.

The residence time for technetium in sediments depends on the redox state, which in turn depends on the $E_{\mathrm{h}}$ of the system. An $E_{\mathrm{h}}$ of approximately +200 to $+100 \mathrm{mV}$ at $\mathrm{pH} 7$ is needed to reduce $\mathrm{Tc}(\mathrm{VII})$ (Lieser and Bauscher 1987), but reduction was catalytically aided by reactions at mineral surfaces of oxyhydroxides and sulfides. The presence of sorbed Fe(II) on mineral surfaces appears to be a key to inducing Tc(VII) reduction, despite the overall $E_{\mathrm{h}}$ of the system. The redox state of the sediments varied between +180 to $+270 \mathrm{mV}$ (mildly anoxic), with the $E_{\mathrm{h}}$ nearly coincident with the manganese redox couple, and above that of the iron couple. Experiments have shown that the $E_{\mathrm{h}}$ must be below +300 to 
form $\mathrm{Mn}(\mathrm{II})$, but an $E_{\mathrm{h}}$ of $-100 \mathrm{mV}$ is necessary before evidence of $\mathrm{Fe}(\mathrm{II})$ formation. Thus, there is the possibility that that the presence of $\mathrm{Mn}(\mathrm{IV})$ is buffering the $E_{\mathrm{h}}$ of the sediments and thereby preventing the evolution of $\mathrm{Fe}(\mathrm{II})$ (c.f., Heron and Christensen 1995) and, therefore, the reduction of Tc(VII). Yet, despite the overall mildly anoxic character of the sediments, and the relative lack of $\mathrm{Fe}(\mathrm{II})$, and the periodic upwelling of pore solutions from the underlying sand and gravel deposits, technetium is relatively immobile in the tidal sediments. The authors speculate that technetium immobility has more to do with reduction resulting from the presence of iron sulfide phases than with particle size of the sediments.

The studies cited above further highlight the importance of iron and sulfur geochemistry on the fate of technetium, but the character of any bioprecipitated FeS phase has been elusive. Accordingly, coprecipitation of technetium (and rhenium) with iron sulfide minerals was studied by Wharton et al. (2000). The mineral mackinawite (tetragonal FeS) was synthesized in the presence of either reduced or oxidized technetium or rhenium. Mackinawite was chosen because it is the first iron sulfide mineral that forms in a paragenetic sequence. The synthesis materials and the products of re-oxidation experiments were studied using XAS to characterize the technetium and rhenium bonding environments and oxidation states.

Formation of mackinawite caused reduction of $\mathrm{Tc}(\mathrm{VII})$ and $\mathrm{Re}(\mathrm{VII})$ and co-precipitation of a $\mathrm{TcS}_{2}$ phase. Synthesis of FeS in the presence of either Tc(IV) or Re(IV) resulted in no change in the oxidation state of either metal. When exposed to an oxidizing atmosphere, the coordinating atoms around Tc(IV) switch from sulfur to oxygen. Bond lengths and coordination numbers of the technetium compound are characteristic of $\mathrm{TcO}_{2}$-like structure, even though iron is oxidized and secondary goethite forms. The data show that when iron is oxidized, technetium remains in a reduced state, although it is not entirely clear why this happens or how long Tc(IV) will remain reduced.

Similar experiments were performed by Livens et al. (2004), in which mackinawite was synthesized inorganically and then reacted with a solution containing $\mathrm{Tc}(\mathrm{VII}) \mathrm{O}_{4}{ }^{-}$. Contact of the technetium-bearing solution with mackinawite crystals resulted in the surface sorption and co-precipitation of Tc(IV) $\mathrm{S}_{2}$-like phases. As in the experiments of Wharton et al. (2000), upon oxidation the FeS phase transforms into goethite $(\alpha-\mathrm{FeO} \cdot \mathrm{OH})$, and the $\mathrm{Tc}-\mathrm{S}$ bond is replaced by $\mathrm{Tc}-\mathrm{O}$, but technetium remains in a reduced form. Livens et al. (2004) speculate that because Tc(IV) is six-fold coordinated, just like Fe(III) in goethite, that technetium is incorporated into the goethite lattice. If this partitioning occurs in the environment, either naturally or by artificial addition of FeS to the subsurface, then an effective means to immobilize technetium could be realized.

Partitioning of Tc(IV) into or co-precipitation with iron phases can occur only when technetium has been reduced. The next section indicates that reduction can occur, but the mechanisms require the action of microbial species. Further, reduction of pertechnetate is intimately tied with the geochemistry of iron and sulfur. 



\subsection{Biogeochemistry}

\subsection{Microorganisms in the Environment and Bioreduction}

A major breakthrough in geochemistry since the earlier reviews of technetium chemistry was the recognition that microbial activity affects the redox state of metals and, thereby, affects their mobility in the environment. A wide range of endemic bacteria are able to couple oxidation of $\mathrm{H}_{2}$ and organic material to metal reduction during anaerobic respiration. One such set of microbes are the dissimilatory metal reducing bacteria (DMRB) (Liu et al. 2002; Lovely 1993; Wildung et al. 2000) and these are well-represented in aquifer (Anderson et al. 2003), marine (Pignolet et al. 1989), and estuarine (Burke et al. 2005, 2006) sediments. Estimates of the number of microbes present in soil varies, but one estimate states that there are up to $10^{8}$ to $10^{9}$ bacteria per gram of soil, although only a fraction of these are active at any given time (Henrot 1989 and references therein). Even in relatively oligotrophic sediments in which the sediments are heavily contaminated by radioactive elements, viable populations of microorganisms have been documented (Fredrickson et al. 2004a), although the size of the population is relatively small compared to more hospitable environments. Stimulating the growth and active anaerobic respiration of environmentally-limited population may be possible if the soil were amended with an electron donor source. Therefore, there is a strong prospect that the oxidized form of technetium, $\mathrm{Tc}(\mathrm{VII}) \mathrm{O}_{4}{ }^{-}$, may be reduced to hydrous $\mathrm{Tc}(\mathrm{IV}) \mathrm{O}_{2}$-like or a $\mathrm{Tc}(\mathrm{IV}) \mathrm{S}_{2}$ solids and the mobility of technetium thus hindered.

Henrot (1989) showed, for example, that water-bearing sediments inoculated with the sulfate-reducing obligate anaerobe, Deslufovibrio vulgaris and D. gigas, resulted in a loss of technetium from solution. She speculated that during sulfate reduction, biologically aided precipitation of sulfides of technetium $\left(\mathrm{TcS}_{2}\right.$ and $\left.\mathrm{Tc}_{2} \mathrm{~S}_{7}\right)$ occurred outside the cell outer membrane. Gram-negative and -positive marine bacteria, Moraxella sp. and Planococcus sp., respectively, reduced technetium, but only under anaerobic conditions (Pignolet et al. 1989), a finding consistent with that of Henrot (1989). Subsequently, a wide variety of anaerobic microbes have been shown to reduce Tc(VII), including Geobacter metallireducens (Lloyd and McCaskie 1996), Geobacter sulfurreducens (Lloyd et al. 2000), Escherichia coli (Lloyd et al. 1997), Desulfovibrio desulfuricans (Lloyd et al. 1999), Shewanella putrefacians (Wildung et al. 2000), Desulfovibrio fructosovorans (De Luca et al. 2001). An additional number of investigators also noted that technetium behaves as a reduced form in near-surface terrestrial sediments that are periodically waterlogged (Ishii et al. 2004a; 2004b; Tagami and Uchida 1999) that would otherwise expected to be oxidizing. In these settings, oxidation of organic material by microorganism yields a local oxygen-depleted zone in which in which facultative anaerobic bacteria thrive and technetium is reduced. In these microenvironments oxygen is diffusion-limited, so reoxidation and remobilization of technetium, even in an overall oxidizing setting, is hampered.

Because a number of other terminal electron-accepting species exist in natural sediments, such as $\mathrm{Fe}(\mathrm{III})$ and $\mathrm{Mn}(\mathrm{III}, \mathrm{IV})$, and in contaminated aquifers, such as nitrate, that have a higher reduction potential, reduction of $\mathrm{Tc}(\mathrm{VII})$ typically occurs later in the sequence as progressive anoxia develops (e.g., Abdelouas et al. 2002; Burke et al. 2005; Fredrickson et al. 2004b; and Istok et al. 2004). Although this can cause problems in successfully treating contaminated sediments, the production of biogenic reduced solids and reduced aqueous species, such as Fe(II), can have a strong bearing on the fate and transport of technetium. The mechanisms by which technetium is reduced, either by direct enzymatic or an indirect processes, is discussed below. 


\subsection{Reduction by Direct Enzymatic Activity}

A number of investigations have established that a variety of metal- and sulfate-reducing bacteria, especially those of the Shewanella, Desulfovibrio, Anaeromyxobacter and Geobacter species, can induce reduction of Tc(VII) enzymatically (De Luca et al. 2001; Liu et al. 2002; Lloyd et al. 1997; Lloyd et al. 1999; Lloyd et al. 2000; Marshall et al. in press; Wildung et al. 2000). DMRB couple oxidation of $\mathrm{H}_{2}$ and, to a lesser degree, organic matter to reduction of $\mathrm{Tc}(\mathrm{VII})$ via enzymatic electron transfer reactions.

Recent work has centered on understanding the role of a class of hydrogenase enzymes on the metal reduction process (Marshall et al. 2008). In particular, attention has been focused on the sulfur-bridged di-iron and nickel-iron (designated as [FeFe] and [FeNi], respectively) forms, shown in (Figure 8.1). These enzymes catalyze the oxidation of molecular dihydrogen $\left(\mathrm{H}_{2}\right.$ oxidation $)$ and reduction of protons $\left(\mathrm{H}_{2}\right.$ evolution) that comprises the bi-directional redox reaction of hydrogen. The metalloclusters in the $[\mathrm{FeFe}]$ and [FeNi] proteins, which consist of iron and nickel coordinated by carbon monoxide (CO) and cyanide $(\mathrm{CN})$ ligands, are the localities where catalysis takes place. Hydrogenase is typically found in the periplasmic and cytoplasmic regions of cells; in gram-negative cells, the periplasm is located between the outer and inner membranes (Figure 8.2). The close association of technetium solids on the outer membrane or within the periplasm, and not within the cytoplasmic region, is often cited as indirect evidence for the agency of hydrogenase.

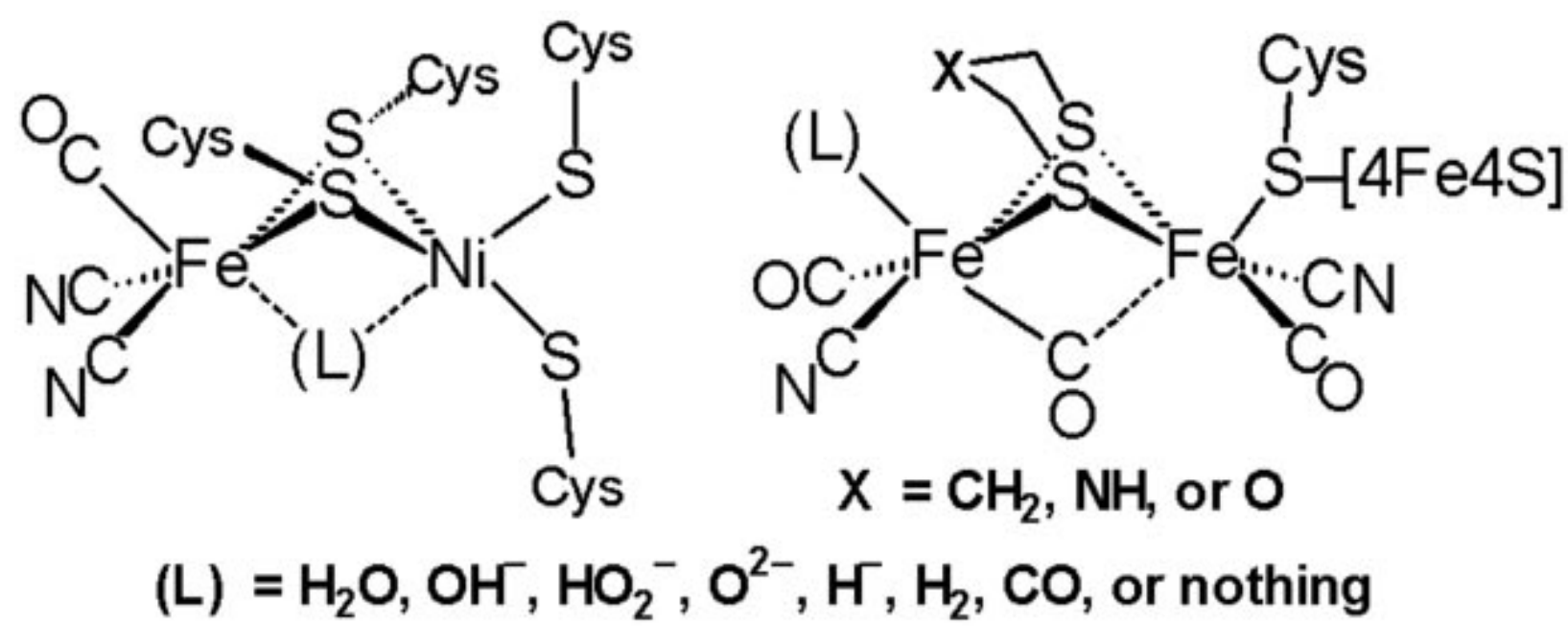

Figure 8.1. Structural Diagrams of the Active Sites of [FeNi] (Left) and [FeFe] (Right) Hydrogenase Proteins 


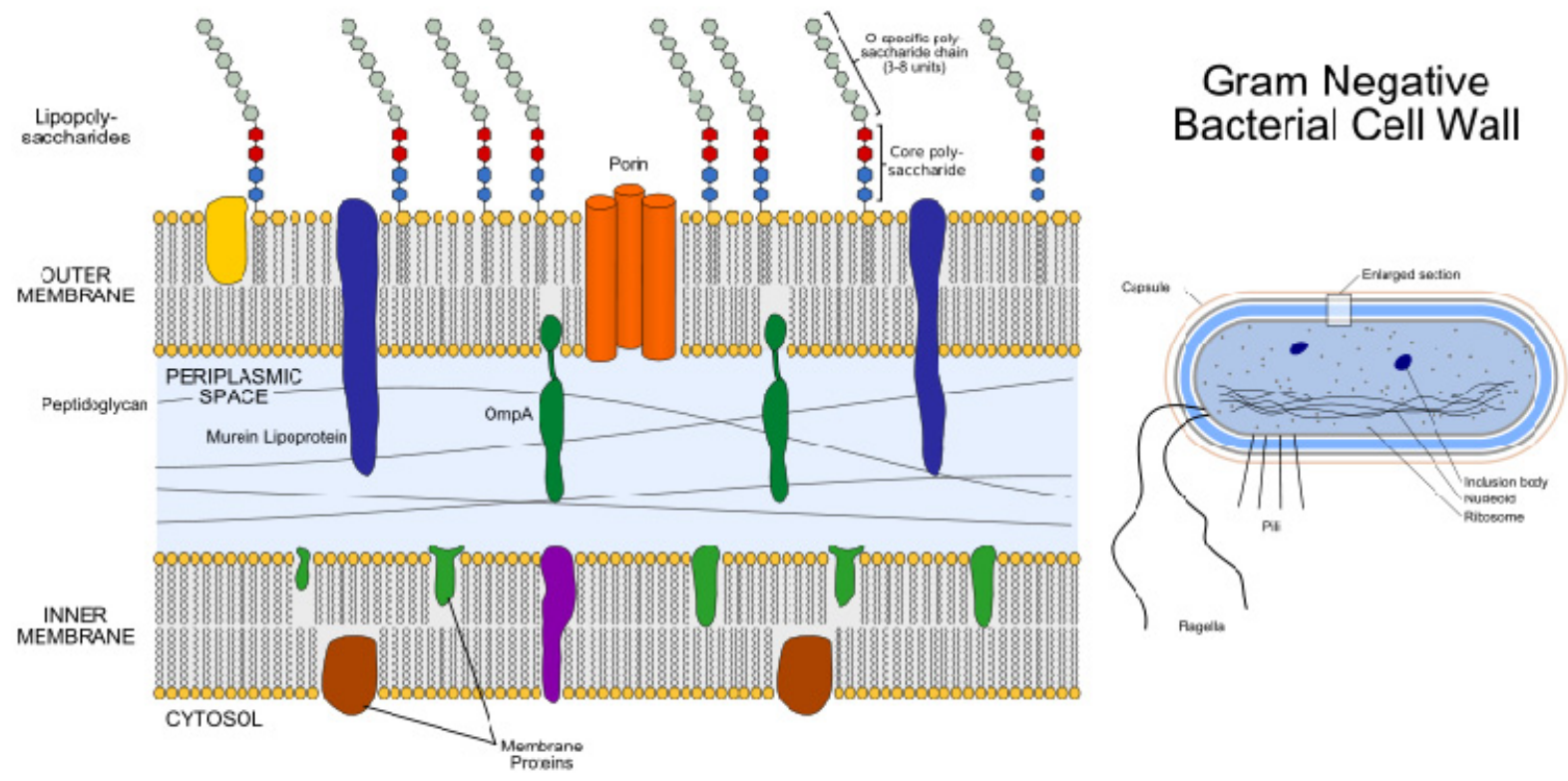

Figure 8.2. A Cartoon Cross-Section Showing the Inner and Outer Membranes Separated by the Periplasmic Space in a Gram-Negative Bacterial Cell Wall (Dahl 2008). Reduction of $\mathrm{Tc}(\mathrm{VII})$ occurs through catalysis by hydrogenase and cytochrome enzymes in the periplasm or on the surface of the outer membrane.

Other lines of evidence strongly indicate that hydrogenase plays a direct role in technetium reduction. Lloyd et al. (1999) reported that cells of Desulfovibrio desulfuricans poisoned with $\mathrm{Cu}(\mathrm{II})$, which deactivates periplasmic, but not cytoplasmic, hydrogenase, were unable to reduce Tc(VII). A similar finding was reported by De Luca et al. (2001) for D. fructosovorans, and they additionally showed that strains lacking in the [FeNi] hydrogenase operon possessed a strongly diminished ability to reduce Tc(VII).

Intimately involved in redox catalysis are the physiological electron donors or acceptors for hydrogenase, such as ferredoxins, cytochrome $\mathrm{c}_{3}$, and cytochrome $\mathrm{c}_{6}$. The role of cytochromes in metal reduction has been discussed by Shi et al. (2006, 2007). Although De Luca et al. (2001) argued that cytochrome $\mathrm{c}_{3}$, for example, does not directly reduce technetium, the presence of this enzyme with hydrogenase is considered to be necessary, though not sufficient, for reduction. In contradiction to this evidence, Marshall et al. (2008) argued for a direct role of outer membrane $c$-type cytochromes (OMCs) in reduction of pertechnetate to Tc(IV). A mutant of Shewanella oneidensis MR-1 lacking two decaheme OMCs, MtrC and OmcA, was found to be incapable of reducing pertechnetate in the presence of lactate as an electron donor. Furthermore, when these two OMCs were purified and chemically reduced, both $\mathrm{MtrC}$ and OmcA were oxidized by pertechnetate, thereby providing direct evidence for the electron transfer reaction. It is unclear at this point whether the direct role of OMCs is species-specific to Shewanella sp. or if differences in experimental procedures led to different conclusions.

In most of these studies, bio-reduced technetium [Tc(IV)] was manifested as a dark precipitate formed mainly within the periplasmic space and on the exterior surfaces of the cell outer membrane (Lloyd et al. 1997; 2000; Wildung et al. 2000). The black Tc(IV) precipitate that was characterized by Selected Area Electron Diffraction (SAED) (Wildung et al. 2000) and Transmission Electron Microscopy 
(TEM) in experiments with S. putrefaciens (Liu et al. 2002; Marshall et al. 2008; Wildung et al. 2000), G. sulfurreducens (Lloyd et al. 2000), and E. coli (Lloyd et al. 1997) and was shown to be amorphous to nanocrystalline. A number of atom-specific analytical techniques, including Proton-Induced X-ray Emission (PIXE) (Lloyd et al. 1997) and Energy Dispersive X-ray (EDX) (Abdelouas et al. 2002; Liu et al. 2002; Lloyd et al. 2000; Marshall et al. 2008; Wildung et al. 2000) analyses, indicate that technetium and oxygen, and not iron or sulfur, were the major components of the solid. XAS confirmed that the technetium solid was in a reduced form and had Tc-O bond lengths (approximately $2.00 \AA$ ) that are characteristic of hydrous $\mathrm{Tc}(\mathrm{IV}) \mathrm{O}_{2}$-like solids, even in systems that contained sulfur (Burke et al. 2005). In some instances, it appears that technetium co-precipitates with iron sulfide phases (Abdelouas et al. 2002). However, even when sulfide minerals form, other investigations have shown that $\mathrm{TcO}_{2}-1$ ike bonding environments persist when the sulfide phase is oxidized (Livens et al. 2004; Wharton et al. 2000; see below). These data indicate that hydrated $\mathrm{TcO}_{2}$ solids are the long-term reservoir of technetium that forms as a result of biological activity.

\subsection{Reduction of $\mathrm{Tc}(\mathrm{VII})$ Via Biogenic Iron (II) Catalysis}

Investigators have noted that an indirect route to reduction of technetium is also possible when ferric iron is reduced to the ferrous form through the agency of DMRB (Burke et al. 2005; Fredrickson et al. 2004b; Lloyd et al. 2000; Peretyazhko et al. 2008a; Zachara et al. 2007). As discussed previously, the reduction of $\mathrm{Tc}(\mathrm{VII})$ by $\mathrm{Fe}(\mathrm{II})$ is thermodynamically feasible, although kinetically hindered as a homogeneous reaction (Cui and Eriksen 1996b). In addition, surface-mediated reduction, such as Tc(VII) on the surface of magnetite $\left(\mathrm{Fe}_{3} \mathrm{O}_{4}\right)$, is possible but ferrous iron preferentially reacts with dissolved oxygen such that Tc(IV) does not form (Farrell et al. 1999). In anoxic environments, $\mathrm{Fe}(\mathrm{II})$ that is sorbed onto mineral surfaces, especially iron oxyhydroxides $\left(\mathrm{Fe}_{3} \mathrm{O}_{4}, \alpha-\mathrm{FeO} \cdot \mathrm{OH}\right.$, or $\left.\gamma-\mathrm{FeO} \cdot \mathrm{OH}\right)(\mathrm{Begg}$ et al. 2007; Cui and Eriksen 1996a; Lloyd et al. 2000; Peretyazhko et al. 2008a and 2008b; Zachara et al. 2007) causes rapid $\mathrm{Tc}(\mathrm{VII})$ reduction in a heterogeneous, surface-mediated reaction. Ferrous [Fe(II)] iron is present in numerous phases typical of sedimentary environments, including magnetite, ilmenite, phyllosilicates (e.g., chlorite, saponite, and biotite), and amphiboles. However, the availability of Fe(II) as a reductant for Tc(VII) in silicate minerals is limited (Cui and Eriksen 1996b; Fredrickson et al. 2004b).

Note that in the experiments where Tc(VII) was reduced, biological activity does not necessarily have to be ongoing (e.g., Fredrickson et al. 2004b; Marshall et al. 2009; Peretyazhko et al. 2008a; Zachara et al. 2007). In these studies, iron-containing sediments or synthetic iron oxides were supplied to DMBR in the presence of an electron donor source and the production of acid-extractable Fe(II) was monitored over time. The lack of evidence for biogenic Fe(II) minerals (as sought for by Mössbauer spectroscopy) indicated that Fe(II) was manifested as soluble forms that were sorbed onto minerals surfaces. Once significant quantities of Fe(III) had been reduced, cells were inactivated and pertechnetate was added to the assay and the disappearance of Tc(VII) from solution was observed. Concentrations of Tc(VII) dropped rapidly in the biogenically altered sediments, whereas a control experiment revealed no drop in pertechnetate concentration. Characterization of the technetium solids by XAS techniques indicated the presence of a reduced $\mathrm{TcO}_{2}$-like phase (Fredrickson et al. 2004b). In similar experiments, Zachara et al. (2007) reported that technetium appears to have co-precipitated with iron oxyhydroxides. Significantly, technetium was not remobilized when these materials were exposed to oxidizing conditions, suggesting that a biologically indirect process could favorably affect the transport and fate of technetium in contaminated sediments. 
A number of other investigations have also shown that the biogenic production of iron sulfides, such as mackinawite (tetragonal FeS), pyrrhotite $\left(\mathrm{Fe}_{7} \mathrm{~S}_{8}\right)$, and greigite $\left(\mathrm{Fe}_{3} \mathrm{~S}_{4}\right)$, will cause reduction and coprecipitation with Tc(IV) (Abdelouas et al. 2002; Watson et al. 2001). As discussed above, mackinawite oxidizes to form goethite-like phases and technetium becomes bonded to oxygen atoms (Livens et al. 2004; Wharton et al. 2000). However, the experiments showed that even though iron was oxidized, the technetium remained in the +4 state, either as substitution for $\mathrm{Fe}(\mathrm{III})$, or as a $\mathrm{TcO}_{2}(\mathrm{~s})$ co-precipitate within iron oxyhydroxides.

\subsection{Reduction Coupled with Sulfur Reduction}

Sulfur, in a variety of forms, is present in most sedimentary environments. Respiration by certain bacteria causes sulfate to reduce to sulfide, where it can then bind to reduced metals, such as Tc(IV). Production of Tc sulfides is a potentially important process, because the sulfide minerals are insoluble in aqueous solution, so precipitation will cause the concentration of technetium in groundwater to rapidly decrease. A number of investigators have documented that Shewanella putrefaciens, Shewanella algae, Geobacter metallireducens, and Desulfovibrio desulfuricans can couple reduction of sulfur to oxidation of organic carbon. Under these conditions, Tc(VII) is also reduced.

Batch tests carried out by Abdelouas et al. (2002) on soil (clayey and sandy) and groundwater or sterilized groundwater were used to determine the interaction of technetium with sulfur- or nitrogenreducing bacteria. The bacteria were indigenous to the soil tested and are considered to be naturally widespread in soil and groundwater. The test materials were amended by addition of lactate and phosphate (because the systems were both C- and P-limited) as well as either nitrate or sulfate.

The concentration of technetium did not diminish when the system underwent de-nitrification, and these results contrast with those of Istok et al. (2004). When both lactate and phosphate were present, nitrate concentrations rapidly diminished from $310 \mathrm{mg} / \mathrm{L}$ to $<1 \mathrm{mg} / \mathrm{L}$. Because de-nitrification consumes hydronium, the $\mathrm{pH}$ of the solution increases, while the $E_{\mathrm{h}}$ of solution remains relatively constant. Note that the behavior of technetium is different from that of uranium, in that de-nitrification results in a 45 percent decrease in soluble uranium because of biosorption or co-precipitation with calcite.

On the other hand, respiration by sulfate-reducing bacteria caused a reduction in the concentration of technetium. Removal of technetium by sulfate-reducing bacteria likely results from reduction of technetium to form either/or $\mathrm{TcO}_{2}$ or $\mathrm{TcS}_{2}$. Sulfate reduction can be written as:

$$
3 \mathrm{SO}_{4}{ }^{2-}+2 \mathrm{C}_{3} \mathrm{H}_{5} \mathrm{O}_{3}^{-}=6 \mathrm{HCO}_{3}^{-}+3 \mathrm{HS}^{-}+\mathrm{H}^{+}
$$

Consistent with the de-nitrification experiments, when both sulfate and nitrate were present, denitrification occurred first (with a characteristic increase in $\mathrm{pH}$ and maintenance of constant $E_{\mathrm{h}}$ ) and then sulfate reduction commences. The initiation of sulfate reduction is marked by the sharp drop in $E_{\mathrm{h}}$ and the formation of a black precipitate. Analysis of the solution and solid precipitates revealed that the concentration of $\mathrm{Fe}$ (II) increased and that the identity of the solid is mackinawite (tetragonal FeS). Closer scrutiny of the solids revealed that the mackinawite is mainly found in cell walls of microorganisms and that technetium is associated with the FeS phase. Autoclaved materials containing nitrate, lactate, and phosphate showed no reduction of technetium, which strongly implicates the importance of biologic processes in technetium immobilization. Further, experiments spiked with inorganic $\mathrm{S}^{2-}$, but lacking in nitrate, sulfate, lactate and phosphate evidenced minor reduction of technetium, but nowhere near the 
extent of reduction that occurred during ongoing bacteria growth. The investigators conclude that addition of inorganic forms of sulfide is insufficient to remove technetium from groundwater.

\subsection{Reduction Coupled with De-nitrification}

For many cases of environmental remediation, the aqueous solution containing dissolved technetium also contains nitrate. For example, many of the solutions leaked from single-shell tanks at Hanford Site in Washington State, are nitrate-rich. Accordingly, it is imperative to understand how the presence of milligram to gram per liter concentrations of nitrate will affect technetium reduction and precipitation.

Istok et al. (2004) performed field experiments in which bioreduction of $\mathrm{NO}_{3}^{-}, \mathrm{Tc}(\mathrm{VII})$ and $\mathrm{U}(\mathrm{VI})$ was attempted by adding an electron donor (ethanol, glucose, or acetate). In the absence of an electron donor, reduction of the target molecules was not achieved. However, upon addition of an electron donor, rapid $\mathrm{NO}_{3}{ }^{-}$reduction was observed. The buildup of $\mathrm{NO}_{2}{ }^{-}$and the lack of detectable $\mathrm{NH}_{4}{ }^{+}$suggest that nitrate was being consumed because of the de-nitrification reaction:

$$
12 \mathrm{NO}_{3}^{-}+5 \mathrm{C}_{3} \mathrm{H}_{5} \mathrm{O}_{3}^{-}+2 \mathrm{H}^{+}=6 \mathrm{~N}_{2}+15 \mathrm{HCO}_{3}^{-}+6 \mathrm{H}_{2} \mathrm{O}
$$

They observed a corresponding $\mathrm{Tc}(\mathrm{VII})$ reduction with $\mathrm{NO}_{3}{ }^{-}$reduction. Down-well sampling revealed that addition of electron donor materials resulted in microbial growth, the imposition of anaerobic conditions, and an increase in Geobacter and other metal reducing microorganisms. This investigation demonstrates that even groundwater contaminated by $\mathrm{NO}_{3}{ }^{-}$and containing redox-sensitive elements (technetium and uranium) can be remediated using microorganisms. However, nitrate anions compete with technetium for sorption sites on Fe(II)-bearing minerals (Watson et al. 2001), as predicted from the smaller free energy of hydration $\left(\Delta G_{\text {hyd }}\right)$ of nitrate compared to pertechnetate. Further, reduction of nitrogen appears to be necessary before reduction of technetium can commence, so it may be the case that a bioreduction strategy for nitrate-rich waters will be prohibitively expensive. 


\subsection{Discussion and Recommendations for Future Studies}

The current state of knowledge regarding technetium chemistry is impressive, yet part of the problem related to remediation of technetium-contaminated materials lies in several unresolved problems. One problem stems from a lack of knowledge concerning the association of technetium in sediments-i.e., is technetium sorbed onto or incorporated into solid phases? A number of investigations reveal that experiments aimed at elucidating technetium binding are time-sensitive, such that the identity of the ligand changes because of oxidation or other kinetic factors (Livens et al. 2004; Wharton et al. 2000). Because of the long half-life of ${ }^{99} \mathrm{Tc}$, there is an unsettling prospect that the experiments do not replicate the future environmental setting. Furthermore, studies of technetium in sediments, where the technetium was released either accidentally or intentionally into the environment, have difficulty in identifying the phase or phases with which it is associated because of very low concentrations. Techniques used to extract and concentrate technetium from typical sediments rely on multiple steps in which the accumulation of analytical uncertain can become an important factor. In support of this statement, note that spiking the sediments with an isotopic tracer, such as ${ }^{99 \mathrm{~m}} \mathrm{Tc}$, has revealed poor recovery $(58 \pm$ 6 percent) in some cases (Tagami and Uchida 1997), underscoring the difficulty of extraction procedures. In addition, selective sediment extraction techniques may not be selective enough to adequately constrain the retention of technetium. In particular, use of $\mathrm{H}_{2} \mathrm{O}_{2}$ to oxidize the organic fraction will also oxidize any $\mathrm{TcO}_{2}(\mathrm{~s})$, yielding ambiguous data.

In some cases, there is evidence for uptake of technetium into solid phases that are resistant to oxidation or dissolution. Because the size of the Tc(IV) atom is nearly identical to that of Fe(III) (both $78.5 \AA$ ) and because both metals are 6-fold coordinated, there is a prospect that Tc(IV) can be harbored in the lattice of certain iron-bearing phases. Because of the charge difference between Tc(IV) and Fe(III), the substitution must either be coupled or a defect must be generated. Tc(IV) may be incorporated into iron sulfides, but the proclivity of these phases to oxidize opens questions about how long technetium will remain immobile. Although a number of experiments have shown that technetium remains in the +4 state while the host sulfide oxidizes (Livens et al. 2004; Wharton et al. 2000), there is reasonable concern surrounding the longevity of this state. Long-term experiments in which the paragenetic sequence of sulfide phases evolve towards sulfates, with studies of the corresponding oxidation state of technetium, are needed.

Because of the importance of oxidation-reduction reactions to the mobility of technetium, there should be an emphasis on understanding the chemical fundamentals of these processes. For example, the coupled oxidation-reduction reaction, such as Equation (8), above, is an overall, rather than an elementary, kinetic reaction. It is likely, however, that Equation (8) is composed of a number of elementary reactions that sum together to the overall reaction. Clearly, it would matter a great deal if the elementary reactions were parallel or sequential, because in the case of the latter, there could be ratelimiting steps that have yet to be identified. On the other hand, if the elementary steps were made up of parallel reactions, it would be very useful to understand the relative importance of the various kinetic pathways by which iron and technetium oxidation states evolve. If catalysts or inhibitors to the reaction pathways could be fashioned, then the overall oxidation-reduction scheme could be modified in an environmentally favorable fashion.

Alternatively, if re-oxidation of Tc(IV) is kinetically straightforward and fast, then other studies are needed. The relatively rapid re-oxidation in laboratory experiments appears to contrast to field 
investigations in which technetium remains in the relatively immobile Tc(IV) state. Development of microenvironments, in which the oxidation state on the local scale contrasts with that of the surrounding, general state, has been discussed in the literature (Hu and Smith 2004; $\mathrm{Hu}$ et al. 2008), but experimental evidence for how these conditions evolve are lacking. Carefully conducted laboratory experiments coupled with field studies and computer modeling may elucidate the evolution of such microenvironments. In this case, the blanket assessment that technetium is always mobile in an overall oxidizing setting will need to be clarified and long-term models forecasting the migration of technetium in the environments will need to be modified. 


\subsection{References}

Aarkrog A, S Boelskifte, H Dahlgaard, S Duniec, L Hallstadius, E Holm, and JN Smith. 1987. "Technetium-99 and Cesium-134 as Long Distance Tracers in Arctic Waters." Estuarine, Coastal and Shelf Science 24:637-647.

Aarkrog A, Q Chen, H Dahlgaard, SP Nielsen, A Trapeznikov, and V Pozolotina. 1997. "Evidence of ${ }^{99}$ Tc in Ural River Sediments." Journal of Environmental Radioactivity 37:201-213.

Abdelouas A, M Fattahi, B Grambow, L Vichot, and E Gautier. 2002. "Precipitation of Technetium by Subsurface Sulfate-Reducing Bacteria." Radiochimica Acta 90:773-777.

Anders E. 1960. The Radiochemistry of Technetium. National Academy of Sciences-National Research Council, Washington, D.C.

Anderson BE, U Becker, KB Helean, and RC Ewing. 2007. "Perhenate and Pertechnetate Behavior on Iron and Sulfur-Bearing Compounds." In Scientific Basis for Nuclear Waste Management XXX, eds D Dunn, C Poinssot, and B Begg. Materials Research Society, Warrendale, Pennsylvania.

Anderson RT, HA Vrionis, I Ortiz-Bernad, CT Resch, PE Long, R Dayvault, K Karp, S Marutzky, DR Metzler, A Peacock, DC White, M Lowe, and DR Lovley. 2003. "Stimulating the In Situ Activity of Geobacter Species to Remove Uranium from the Groundwater of a Uranium-Contaminated Aquifer. Applied and Environmental Microbiology 69:5884-5891.

Antonini M, AE Merlini, and RF Thornley. 1985. "EXAFS Structures of Technetium in Glasses Prepared Under Different Redox Conditions.” Journal of Non-Crystalline Solids 71:219-225.

Ashworth DJ and G Shaw. 2005. "Soil Migration and Plant Uptake of Technetium from a Fluctuating Water Table.” Journal of Environmental Radioactivity 81:155-171.

Baston GMN, PR De Canniere, DJ Ilett, MM Cowper, NJ Pilkington, CJ Tweed, L Wang, and SJ Williams. 2002. "Technetium Behaviour in Boom Clay-A Laboratory and Field Study." Radiochimica Acta 90:735-740.

Begg JDC, IT Burke, and K Morris. 2007. "The Behavior of Technetium During Microbial Reduction in Amended Soils from Dounreay, UK." Science of the Total Environment 373:297-304.

Bennett R and N Willey. 2003. "Soil Availability, Plant Uptake and Soil to Plant Transfer of Tc-99 - A Review." Journal of Environmental Radioactivity 65:215-231.

Bondietti EA and CW Francis. 1979. "Geologic Migration Potentials of Technetium-99 and Neptunium237." Science 203:1337-1340. 
Bonotto S, R Kirchmann, J Van Baelen, C Hurtgen, M Cogneau, D Van der Ben, C Verthe, and JM Bouquegneau. 1985. "Behaviour of Technetium in Marine Algae." In Speciation of Fission and Activation Products in the Environment, eds RA Bulman and JR Cooper. Elsevier Applied Science Publishers, London.

Bors J, S Dultz, and B Riebe. 1999. "Retention of Radionuclides by Organophilic Bentonite." Engineering Geology 54:195-206.

Brookins DG. 1990. "Radionuclide Behavior at the Oklo Nuclear Reactor, Gabon." Waste Management 10:285-296.

Brown JE, AK Kolstad, AL Brungot, B Lind, AL Rudjord, P Strand, and L Føyn. 1999. "Levels of ${ }^{99}$ Tc in Seawater and Biota Samples form Norwegian Coastal Waters and Adjacent Seas." Marine Pollution Bulletin 38:560-571.

Bruggeman C, A Maes, and J Vancluysen. 2007. "The Identification of $\mathrm{FeS}_{2}$ as a Sorption Sink for Tc(IV)." Physics and Chemistry of the Earth 32:573-580.

Buck EC, BD Hanson, and BK McNamara. 2004. "The Geochemical Behaviour of Tc, Np, and Pu in Spent Nuclear Fuel in an Oxidizing Environment." In Energy, Waste, and the Environment: A Geochemical Perspective, eds R Gieré and P Stille. The Geological Society of London, London.

Burke IT, C Boothman, JR Lloyd, FR Livens, JM Charnock, JM McBeth, RJG Mortimer, and K Morris. 2006. "Reoxidation Behavior of Technetium, Iron and Sulfur in Esturarine Sediments." Environment Science and Technology 40:3529-3535.

Burke IT, C Boothman, JR Lloyd, RJG Mortimer, FR Livens, and K Morris. 2005. "Effects of Progressive Anoxia on the Solubility of Technetium in Sediments." Environmental Science and Technology 39:4109-4116.

Cartledge GH and WT Smith. 1955. "Revision of the Electrode Potential Diagram for Technetium." Journal of Physical Chemistry 59:1111-1112.

Cataldo DA, TR Garland, RE Wildung, and RJ Fellows. 1989. "Comparative Metabolic Behavior and Interrelationships of Tc and S in Soybean Plants." Health Physics 57:281-287.

Chen F, PC Burns, and RC Ewing. 2000. "Near-Field Behavior of ${ }^{99} \mathrm{TC}$ During the Oxidative Alteration of Spent Nuclear Fuel. Journal of Nuclear Materials 278:225-232.

Cobble JW, WT Smith, and GE Boyd. 1953. “Thermodynamic Properties of Technetium and Rhenium Compounds. II. Heats of Formation of Technetium Heptoxide and Pertechnic Acid, Potential of the Technetium-(IV)-Technetium (VII) Couple, and a Potential Diagram for Technetium." Journal of American Chemical Society 75:5777-5782.

Colton R. 1965. The Chemistry of Rhenium and Technetium. Interscience Publishers, London. 
Cotton FA and G Wilkinson. 1980. Advanced Inorganic Chemistry: A Comprehensive Text, 4th Edition. John Wiley and Sons, New York.

Cui D and TE Eriksen. 1996a. "Reduction of Pertechnetate by Ferrous Iron in Solution: Influence of Sorbed and Precipitated Fe(II).” Environmental Science and Technology 30:2259-2262.

Cui D and TE Eriksen. 1996b. "Reduction of Pertechnetate in Solution by Heterogeneous Electron Transfer from Fe(II)-Containing Geological Material." Environmental Science and Technology 30:22632269.

Curtis DB. 1986. “Geochemical Controls on ${ }^{99}$ Tc Transport and Retention.” Chemical Geology 55:227231.

Curtis D, T Benjamin, A Gancarz, R Loss, K Rosman, J DeLaeter, JE Delmore, WJ Maeck. 1989.

"Fission Product Retention in the Oklo Natural Fission Reactors. Applied Geochemistry 4:49-62.

Dahl J. 2008. "Gram negative cell wall svg," Accessed on December 29, 2008.

http://en.wikipedia.org/wiki/File:Gram_negative_cell_wall.svg (last updated March 2, 2008).

Dahlgaard H, M Eriksson, SP Nielsen, and HP Joensen. 2004. "Levels and Trends of Radioactive Contaminants in the Greenland Environment." Science of the Total Environment 331:53-67.

Darab JG. and PA Smith. 1996. "Chemistry of Technetium and Rhenium Species During Low-Level Radioactive Waste Vitrification.” Chemistry of Materials 8:1004-1021.

De Luca G, P De Philip, Z Dermoun, M Rousset, and A Vermeglio. 2001. "Reduction of Technetium (VII) by Desulfovibrio fructosovorans is Mediated by the Nickel-Iron Hydrogenase." Applied and Environmental Microbiology 67:4583-4587.

Desmet G and C Myttenaere. 1986. Technetium in the Environment. Elsevier Applied Science Publishers, London, England.

Echevarria G, PC Vong, E Leclerc-Cessac, and JL Morel. 1997. "Bioavailability of Technetium-99 as Affected by Plant Species and Growth, Application Form, and Soil Incubation. Journal of Environmental Quality 26:947.

EPA-U.S. Environmental Protection Agency. 2002. EPA Facts About Technetium-99. http://www.epa.gov/superfund//health/contaminants/radiation/pdfs/technetium.pdf

Eriksen TE, P Ndalamba, J Bruno, and M Caceci. 1992. "The Solubility of $\mathrm{TcO}_{2} \cdot n \mathrm{H}_{2} \mathrm{O}$ in Neutral to Alkaline Solutions under Constant $p \mathrm{CO}_{2}$." Radiochimica Acta 58-59, 67-70.

Faggiani R, CJL Lock, and J Poce. 1980. The Structure of Ammonium Pertechnetate at 295, 208 and 141 K.” Acta Crystallographica Section B-Structural Science 36:231-233.

Farrell J, WD Bostick, RJ Jarabek, and JN Fiedor. 1999. "Electrosorption and Reduction of Pertechnetate by Anodically Polarized Magnetite." Environmental Science and Technology 33:12441249. 
Fredrickson, JK, JM Zachara, DL Balkwill, D Kennedy, S-MW Li, HM Kostandarithes, MJ Daly, MF Romine, and FJ Brockman. 2004a. "Geomicrobiology of High-Level Nuclear Waste-Contaminated Vadose Sediments at the Hanford Site, Washington State." Applied and Environmental Microbiology $70: 4230-4241$.

Fredrickson, JK, JM Zachara, DW Kennedy, R Kukkadupa, JP McKinley, SM Heald, C Liu, and AE Plymale. 2004b. "Reduction of $\mathrm{TcO}_{4}{ }^{-}$by Sediment-Associated Biogenic Fe(II). Geochimica et Cosmochimica Acta 68:3171-3187.

Gancarz, A, G Cowan, D Curtis, and WJ Maeck. 1980. “999 Tc, Pb, and Ru Migration Around the Oklo Natural Fission Reactors." Scientific Basis for Nuclear Waste Management II. Elsevier Science Publishing Company, Inc., New York.

Gauthier-Lafaye F, P Holliger, and P-LBlanc. 1996. "Natural Fission Reactors in the Franceville Basin, Gabon: A Review of the Conditions and Results of a "critical event' in a Geologic System." Geochimica Cosmochimica Acta 60:4831-4852.

Gee G, M Oostrom, MD Freshley, ML Rockhold, and JM Zachara. 2007. "Hanford Site Vadose Zone Studies: An Overview." Vadose Zone Journal 6:899-905.

Geraedts K, C Bruggeman, A Maes, LR Van Loon, A Rossberg, and T Reich. 2002. "Evidence for the Existence of Tc(IV)-Humic Substance Species by X-Ray Absorption Near-Edge Spectroscopy." Radiochimica Acta 90:879-884.

Goudard F, MC Milcent, JP Durand, P Germain, F Paquet, and J Pieri. 1998. "Subcellular and Molecular Localization of Different Radionuclides (caesium, americium, plutonium and technetium) in Aquatic Organisms." Radiation Protection Dosimetry 75(1-4):117-124.

Griffith WP. 1967. The Chemistry of the Rarer Platinum Metals (Os, Ru, Ir and Rh). Interscience Publishers, New York.

Gu B, and C Ruan. 2007. "Determination of Technetium and Its Speciation by Surface-Enhanced Raman Spectroscopy." Analytical Chemistry 79:2341-2345.

Harms AV, GC Krijger, JT van Elteren, and JJM de Goeij. 1999. "Characterization of Technetium Species Induced in Spinach.” Journal of Environmental Quality 28(4):1188-1194.

Hartman MJ, LF Morasch, and WD Webber. 2004. Summary of Hanford Site Groundwater Monitoring for Fiscal Year 2003. PNNL-14548-SUM, Pacific Northwest National Laboratory, Richland, Washington.

Harvey BR. and PJ Kershaw. 1984. "Physico-Chemical Interactions of Long-Lived Radionuclides in Coastal Marine Sediments and Some Comparisons with the Deep Sea Environment." CEC International Symposium on the Behaviour of Long-Lived Radionuclides in the Marine Environment, La Spezia, Italy.

Hattink J, JJM de Goeij, and HT Wolterbeek. 2000. "Uptake Kinetics of ${ }^{99}$ Tc in Common Duckweed." Environmental and Experimental Botany 44:9-22. 
Hattink J and HT Wolterbeek. 2001. "Accumulation of ${ }^{99}$ Tc in Duckweed Lemna minor L. as a Function of Growth Rate and ${ }^{99}$ Tc Concentration.” Journal of Environmental Radioactivity 57:117-138.

Henrot J. 1989. "Bioaccumulation and Chemical Modification of Tc by Soil Bacteria." Health Physics 57:239-245.

Heron G and TH Christensen. 1995. "Impact of Sediment-Bound Iron on Redox Buffering in a Landfill Leachate Polluted Aquifer (Vejen, Denmark).” Environment Science and Technology 29:187-192.

Hess NJ, Y Xia, D Rai, and SD Conradson. 2004. "Thermodynamic Model for the Solubility of $\mathrm{TcO}_{2} \times \mathrm{H}_{2} \mathrm{O}(\mathrm{am})$ in the Aqueous $\mathrm{Tc}(\mathrm{IV})-\mathrm{Na}^{+}-\mathrm{Cl}^{-}-\mathrm{H}^{+}-\mathrm{OH}^{-}-\mathrm{H}_{2} \mathrm{O}$ System." Journal of Solution Chemistry 33:199-226.

Hidaka H, P Holliger, and F Gauthier-Lafaye. 1999. Tc/Ru Fractionation in the Oklo and Bangombe Natural Fission Reactors, Gabon.” Chemical Geology 155:323-333.

Hidaka H, K Shinotsuka, and P Holliger. 1993. "Geochemical Behaviour of ${ }^{99}$ Tc in the Oklo Natural Fission Reactors.” Radiochimica Acta 63:19-22.

$\mathrm{Hu} \mathrm{Q}$ and DK Smith. 2004. "Field-Scale Migration of ${ }^{99} \mathrm{Tc}$ and ${ }^{129} \mathrm{I}$ at the Nevada Test Site." Scientific Basis for Nuclear for Nuclear Waste Management. Materials Research Society, Warrendale, Pennsylvania.

Hu QH, TP Rose, M Zavarin, DK Smith, JE Moran, and PH Zhao. 2008. “Assessing Field-Scale Migration of Radionuclides at the Nevada Test Site: 'mobile' species." Journal of Environmental Quality 99:1617-1630.

Huheey JE, EA Keiter, and RL Keiter. 1993. Inorganic Chemistry: Principles of Structure and Reactivity, Fourth Edition HarperCollins College Publishers, New York.

IAEA - International Atomic Energy Agency. 2004. "Sediment Distribution Coefficients and Concentration Factors for Biota in the Marine Environment." Technical Report Series No. 422. International Atomic Energy Association, Vienna, Austria.

Ishii N, K Tagami, S Enomoto, and S Uchida. 2004a. "Influence of Microorganisms on the Behavior of Technetium and Other Elements in Paddy Soil Surface Water." Journal of Environmental Radioactivity 77:369-380.

Ishii N, K Tagami, and S Uchida. 2004b. "Physicochemical Form of Technetium in Surface Water Covering Paddy and Upland Field." Chemosphere 57:953-953.

Istok JD, JM Senko, LR Krumholz, D Watson, MA Bogle, A Peacock, Y-J Chang, and DC White. 2004. "In Situ Bioreduction of Technetium and Uranium in a Nitrate-Contaminated Aquifer." Environment Science and Technology 38:468-475.

Janeczek, J. 1999. "Mineralogy and Geochemistry of Natural Fission Reactors in Gabon." In Uranium: Mineralogy, Geochemistry and the Environment, eds PC Burns and R Finch. Mineralogical Society of America, Washington, D.C. 
Johnson SG, M Noy, T DiSanto, and TL Barber. 2002. "Release of Neptunium, Plutonium, Uranium and Technetium from the Metallic Waste Form From the Electrometallurgical Treatment Process." Scientific Basis for Nuclear Waste Management. Materials Research Society, Warrendale, Pennsylvania.

Jurisson S, J Gawenis, and ER Landa. 2004. "Sorption of ${ }^{99 m}$ Tc Radiopharmaceutical Compounds by Soils." Health Physics 87:423-428.

Kaplan DI. 2003. "Influence of Surface Charge of an Fe-Oxide and an Organic Matter Dominated Soil on Iodide and Pertechnetate Sorption." Radiochimica Acta 91:173-178.

Kaplan DI and RJ Serne. 1998. "Pertechnetate Exclusion from Sediments." Radiochimica Acta 81:117124.

Keith-Roach MJ and P Roos. 2004. "Redox-Dependent Behaviour of Technetium-99 Entering Permanently Stratified Anoxic Fjord (Framvaren fjord, Norway)." Estuarine, Coastal and Shelf Science 60:151-161.

Kenna HW and PK Kuroda. 1961. "Isolation of Naturally Occurring Technetium.” Journal of Inorganic Nuclear Chemistry 23:142-144.

Kim E and J Boulègue. 2003. "Chemistry of Rhenium as an Analogue of Technetium: Experimental Studies of the Dissolution of Rhenium Oxides in Aqueous Solutions." Radiochimica Acta 91:211-216.

Kim E, MF Benedetti, and J Boulègue. 2004. "Removal of Dissolved Rhenium by Sorption onto Organic Polymers: Study of Rhenium as an Analogue of Radioactive Technetium." Water Research 38:448-454.

Kleykamp H. 1985. "The Chemical State of the Fission Products in Oxide Fuels." Journal of Nuclear Materials 131:221-246.

Kloosterman JL. 2008. "Nuclear Waste Production.” Accessed June 26, 2008 at http://wwwtest.iri.tudelft.nl/ klooster/reports.php (last updated November 2008).

Koch-Steindl H and G Pröhl. 2001. "Considerations on the Behaviour of Long-Lived Radionuclides in the Soil." Radiation and Environmental Biophysics 40:93-104.

Kotegov KV, ON Pavlov, and VP Shvedov. 1968. "Technetium.” In Advances in Inorganic Chemistry and Radiochemistry, eds HJ Emeleus and AG Sharpe. Academic Press, New York.

Krebs B and K-D Hasse. 1976. "Refinements of the Crystal Structures of $\mathrm{KTcO}_{4}, \mathrm{KReO}_{4}$ and $\mathrm{OsO}_{4}$. The Bond Lengths in Tetragonal Oxo-Anions and Oxides of the $d^{0}$ Transition Metals." Acta Crystallographica B 32:1334-1337.

Krijger GC, C Kollöffel, HT Wolterbeek. 2000. "Effect of Nitrate on Uptake of Pertechnetate by Tomato Plants." Journal of Environmental Quality 29(3):866-870. 
Krupka KM, CF Brown, HT Schaef, SM Heald, MM Valenta, and BW Arey. 2006. "Rhenium uptake as Analogue for ${ }^{99} \mathrm{Tc}$ by Steel Corrosion Products." In Proceedings of the 11th International High-Level Radioactive Waste Management Conference (IHLRWM), ed B Sagar. American Nuclear Society, Las Vegas, Nevada.

Langmuir D. 1997. Aqueous Environmental Geochemistry. Prentice Hall, Upper Saddle River, New Jersey.

Lemire RJ and DJ Jobe. 1996. "Predicted Behaviour of Technetium in a Geological Disposal Vault for Used Nuclear Fuel-Ramifications of a Recent Determination of the Enthalpy of Formation of $\mathrm{TcO}_{2}$ (cr)." In Scientific Basis for Nuclear Waste Management XIX, eds WM Murphy and DA Knecht. Materials Research Society, Warrendale, Pennsylvania.

Liang L, B Gu, and X Yin. 1996. "Removal of Technetium-99 from Contaminated Groundwater with Sorbents and Reductive Materials.” Separations Technology 6:111-122.

Liebscher I and R Münze. 1975. Bestimmung des standardpotentials der halbkette $\mathrm{TcO}_{4}{ }^{-} / \mathrm{TcO}_{2} \mathrm{xH}_{2} \mathrm{O}$. Zentralinstitut fur Kernforschung, Tech. Rep. ZFK-294, Rossendorf, German Democratic Republic.

Lieser KH and C Bauscher. 1987. "Technetium in the Hydrosphere and in the Geosphere. I. Chemistry of Technetium and Iron in Natural Waters and Influence of the Redox Potential on the Sorption of Technetium." Radiochimica Acta 42:205-213.

Lieser KH, CH Bauscher, and T Nakashima. 1987. "Dissolution of $\mathrm{TcO}_{2}$ in Aqueous Solutions Under Various Conditions." Radiochimica Acta 42:191-200.

Lindahl P, C Ellmark, T Gafvert, S Mattsson, P Roos, E Holm, and B Erlandsson. 2003. "Long-Term Study of ${ }^{99} \mathrm{Tc}$ in the Marine Environment on the Swedish West Coast." Journal of Environmental Radioactivity 67:145-146.

Liu C, YA Gorby, JM Zachara, JK Fredrickson, and CF Brown. 2002. "Reduction Kinetics of Fe(III), $\mathrm{Co}(\mathrm{III}), \mathrm{U}(\mathrm{VI}), \mathrm{Cr}(\mathrm{VI})$, and Tc(VII) in Cultures of Dissimilatory Metal-Reducing Bacteria." Biotechnology and Bioengineering 80:637-649.

Livens FR, MJ Jones, A Hynes, JM Charnock, FW Mosselmans, C Hennig, H Steele, D Collison, DJ Vaughn, RAD Pattrick, WA Reed, and LN Moyes. 2004. "X-Ray Absorption Spectroscopy Studies of Reactions of Technetium, Uranium and Neptunium with Mackinawite." Journal of Environmental Radioactivity 74:211-219.

Lloyd JR, and LE Macaskie. 1996. "A Novel Phosphorimager-Based Technique for Monitoring the Microbial Reduction of Technetium.” Applied and Environmental Microbiology 62:578-582.

Lloyd JR, JA Cole, and LE Macaskie. 1997. "Reduction and Removal of Heptavalent Technetium from Solution by Escherichia coli." Journal of Bacteriology 179:2014-2021.

Lloyd JR, J Ridley, NN Khizniak, NN Lyalikova, and LE Macaskie. 1999. "Reduction of Technetium by Desulfovibrio desulfuricans: Biocatalyst Characterization and Use in a Flowthrough Bioreactor." Applied and Environmental Microbiology 65:2691-2696. 
Lloyd JR, VA Sole, CVG Van Praagh, and DR Lovley. 2000. "Direct and Fe(II)-Mediated Reduction of Technetium by Fe(III)-Reducing Bacteria." Applied and Environmental Microbiology 66:3743-3749.

Lovely DR. 1993. "Dissimilatory Metal Reduction.” Annual Reviews in Microbiology 47:263-290.

Lukens WW, JJ Bucher, NM Edelstein, and DK Shuh. 2002. "Products of Pertechnetate Radiolysis in

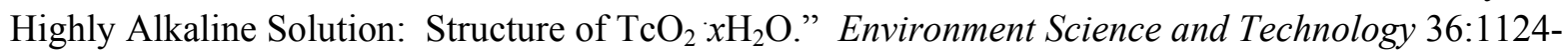
1129.

Lukens WW, DK Shuh, IS Muller, and DA McKeown. 2004. "X-Ray Absorption Fine Structure Studies of Speciation of Technetium in Borosilicate Glasses." Scientific Basis for Nuclear Waste Management. Materials Research Society, Warrendale, Pennsylvania.

Luykx, F. 1984. "Technetium Discharges into the Environment." In Technetium in the Environment, eds G Desmet and C Myttenaere. Elsevier, Essex, England.

Maes A, K Geraedts, C Bruggeman, J VanCluysen, A Rossberg, and C Henning. 2004. "Evidence for the Interaction of Technetium Colloids with Humic Substances by X-Ray Absorption Spectroscopy." Environmental Science and Technology 38:2044-2051.

Marshall MJ, AE Plymale, DW Kennedy, L Shi, Z Wang, SB Reed, AC Dohnalkova, CJ Simonson, C Liu, DA Saffarini, MF Romine, JM Zachara, AS Beliaev, and JK Fredrickson. 2008. Hydrogenase- and outer membrane $c$-type cytochrome-facilitated reduction of technetium (VII) by Shewanella oneidensis MR-1. Environmental Microbiology 10:125-136.

Marshall, MJ, AC Dohnalkova, DW Kennedy, AE Plymale, SH Thomas, FE Löffler, RA Sanford, JM Zachara, JK Fredrickson, AS Beliaev. In press. "Electron Donor-Dependent Radionuclide Reduction and Nanoparticle Formation by Anaeromyxobacter dehalogenans Strain 2CP-C." Environmental Microbiology, doi:10.1111/j.1462-2920.2008.01795.x.

Maset ER, SH Sidhu, A Fisher, A Heydon, PJ Worsforld, AJ Cartwright, and MJ Keith-Roach. 2006. "Effect of Organic Co-Contaminants on Technetium and Rhenium Speciation and Solubility Under Reducing Conditions." Environmental Science and Technology 40:5472-5477.

McCubbin D, SL Kinson, P McDonald, R Bonfield, and D Boust. 2006. "Distribution of Technetium-99 in Sub-Tidal Sediments of the Irish Sea." Continental Shelf Research 26:458-473.

McGrail BP, DH Bacon, JP Icenhower, FM Mann, RJ Puigh, HT Schaef, and SV Mattigod. 2001. "Near-Field Performance Assessment for a Low-Activity Waste Glass Disposal System: Laboratory Testing to Modeling Results." Journal of Nuclear Materials 298:95-111.

McKeown DA, AC Buechele, WW Lukens, DK Shuh, and IL Pegg. 2007. "Tc and Re Behavior in Borosilicate Waste Glass Vapor Hydration Tests." Scientific Basis for Nuclear Waste Management. Materials Research Society, Warrendale, Pennsylvania.

Merrill PW. 1952. Spectroscopic Observations of Stars of Class S.” Astrophysics Journal 116:21-26. 
Meyer RE and WD Arnold. 1991. "The Electrode Potential of the Tc(IV)-Tc(VII) Couple." Radiochimica Acta 55:19-22.

Meyer RE, WD Arnold, FI Case, and GD O’Kelley. 1991. "Solubilities of Tc(IV) Oxides." Radiochimica Acta 55:11-18.

Mooney RCL. 1948. “Crystal Structure of Element 43.” Acta Crystallographica 1:161-162.

Morris K, JC Butterworth, and FR Livens. 2000. "Evidence for the Remobilization of Sellafield Waste Radionuclides in an Intertidal Salt Marsh, West Cumbria, U.K." Estuarine, Coastal and Shelf Science 51:613-625.

Morris K, FR Livens, JM Charnock, IT Burke, JM McBeth, JDC Begg, C Boothman, and JR Lloyd. 2008. "An X-Ray Absorption Study of the Fate of Technetium in Reduced and Reoxidised Sediments and Mineral Phases." Applied Geochemistry 23:603-617.

Oliver L, WT Perkins, and SM Mudge. 2006. "Detection of Technetium-99 in Ascophyllum Nodosum from Around the Welsh Coast." Chemosphere 65:2297-2303.

Pauling L. 1947. "Atomic Radii and Interatomic Distances in Metals." Journal of the American Chemical Society 69:542-553.

Peacock RD. 1966. The Chemistry of Technetium and Rhenium. Elsevier Publishing Co., New York, New York.

Peretyazhko T, JM Zachara, SM Heald, B-H Jeon, RK Kukkadapu, C Liu, DA Moore, and CT Resch. 2008a. "Heterogeneous Reduction of Tc(VII) by Fe(II) at the Solid-Water Interface." Geochimica Cosmochimica Acta 72:1521-1539.

Peretyazhko T, JM Zachara, SM Heald, RK Kukkadapu, C Liu, AE Plymale, and CT Resch. 2008b. "Reduction of Tc(VII) by Fe(II) Sorbed on Al (hydr)Oxides." Environmental Science and Technology 42:5499-5506.

Perrier C and E Segrè. 1937a. "Radioactive Isotopes of Element 43.” Nature 140:193-194.

Perrier C and E Segrè. 1937b. "Some Chemical Properties of Element 43." Journal of Chemical Physics 5:712-716.

Pignolet L, F Auvray, K Fonsny, F Capot, and Z Moureau. 1989. "Role of Various Microorganisms on Tc Behavior in Sediments." Health Physics 57:791-800.

Pierce EM, BP McGrail, MM Valenta, and DM Strachan. 2006. "The Accelerated Weathering of a Radioactive Low-Activity Waste Glass Under Hydraulically Unsaturated Conditions: Experimental Results from a Pressurized Unsaturated Flow Test." Nuclear Technology 155:149-165.

Pirlet V. 2001. "Overview of Actinides (Np, Pu, Am) and Tc Release from Waste Glasses: Influence of Solution Composition." Journal of Nuclear Medicine 298:47-54. 
Rard JA. 1985. "Chemistry and Thermodynamics of Ruthenium and Some of its Inorganic Compounds and Aqueous Species.” Chemical Reviews 85:1-39.

Rard JA., MH Rand, G Anderegg, and H Wanner. 1999. "Chemical Thermodynamics of Technetium." In Chemical Thermodynamics, eds MCA Sandino and E Osthols. Elsevier, Amsterdam.

Rudin MJ, C Stanton, RG Patterson, and RS Garcia. 1992. National Low-Level Waste Management Program Radionuclide Report Series, Vol. 2, Technetium-99. DOE/LLW-118, Idaho National Engineering Laboratory Technical Report, Idaho Falls, Idaho.

Schulte EH and P Scoppa. 1987. "Sources and Behavior of Technetium in the Environment." Science of the Total Environment 64:163-179.

Schwochau K. 2000. Technetium: Chemistry and Radiopharmaceutical Applications. Wiley-VCH Verlag, Weinheim, Germany.

Sekine T, H Narushima, Y Kino, H Kudo, M Lin, and Y Katsumura. 2002. "Radiolytic Formation of Tc(IV) Oxide Colloids." Radiochimica Acta 90:611-616.

Sekine T, H Narushima, T Suzuki, T Takayama, H Kudo, M Lin, and Y Katsumura. 2004.

"Technetium(IV) Oxide Colloids Produced by Radiolytic Reactions in Aqueous Pertechnetate Solution." Colloids and Surfaces A 249:105-109.

Sheppard MI and SC Sheppard. 1984. "Technetium Behavior in Soils of the Canadian Shield." In Technetium in the Environment, eds G Desmet and C Myttenarere. Elsevier, Essex, England.

Shi L, B Chen, Z Wang, DA Elias, MU Mayer, YA Gorby, S Ni, BH Lower, DW Kennedy, DS Wunschel, HM Mottaz, MJ Marshall, EA Hill, AS Beliaev, JM Zachara, JK Fredrickson, and TC Squier. 2006. "Isolation of High-Affinity Functional Protein Complex Between OmcA and MtrC: Two Outer Membrane Decaheme c-Type Cytochromes of Shewanella oneidensis MR-1." Journal of Bacteriology 188:4705-4714.

Shi L, TC Squier, JM Zachara, and JK Fredrickson. 2007. "Respiration of Metal (hydr)Oxides by Shewanella and Geobacter: A Key Role for Multihaem c-type Cytochromes." Molecular Microbiology 65:12-20.

Smith V, M Fegan, D Pollard, S Long, E Hayden, and TP Ryan. 2001. “Technetium-99 in the Irish Marine Environment.” Journal of Environmental Radioactivity 56:269-284.

Stalmans M, A Maes, and A Cremers. 1986. "Role of Organic Matter as a Geochemical Sink for Technetium in Soils and Sediments." In Technetium in the Environment, eds G Desmet and C Myttenarere. Elsevier, Essex, England.

Tagami K and S Uchida. 1997. "Concentration of Global Fallout ${ }^{99} \mathrm{Tc}$ in Rice Paddy Soils Collected in Japan.” Environmental Pollution 95:151-154.

Tagami K and S Uchida. 1999. "Chemical Transformation of Technetium in Soil During the Change of Soil Water Conditions.” Chemosphere 38:963-971. 
Thorne MC. 2003. "Estimation of Animal Transfer Factors for Radioactive Isotopes of Iodine, Technetium, Selenium and Uranium.” Journal of Environmental Radioactivity 70:3-20.

Till JE. 1984. "Source Terms for Technetium-99 From Nuclear Fuel Cycle Facilities." In Technetium in the Environment, eds G Desmet and C Myttenarere. Elsevier, Essex, England.

Uchida S, K Tagami, W Rühm, M Steiner, and E Wirth. 2000. "Separation of Tc-99 in Soil and Plant Samples Collected Around the Chernobyl Reactor Using a Tc-Selective Chromatographic Resin and Determination of the Nuclide by ICP-MS." Applied Radiation and Isotopes 53:69-73.

Van Loon L, M Stalmans, A Maes, A Cremers, and M Cogneau. 1986. "Humic Acid Complexes of Technetium: Synthesis and Characterization." In Technetium in the Environment, eds G Desmet and C Myttenarere. Elsevier, Essex, England.

Vandecasteele, CM, JP Dehut, S Van Laer, D Deprins, and C Myttenaere. 1989. "Long-Term Availability of Tc Deposited on Soil after Accidental Releases.” Health Physics 57:247-254.

Vandecasteele CM, CT Garten, R Van Bruwaene, J Janssens, R Kirchmann, and C Myttenaere. 1985. "Chemical Speciation of Technetium in Soil and Plants: Impact on Soil-Plant-Animal Transfer." In Speciation of Fission and Activation Products in the Environment, eds RA Bulman and JR Cooper, Elsevier Applied Science Publishers, London.

Vichot L, G Ouvard, G Montavon, M Fattahi, and B Grambow. 2002. "XAS Study of Technetium (IV) Polymer Formation in Mixed Sulphate/Chloride Media." Radiochimica Acta 90:575-579.

Wagman DD, WH Evans, VB Parker, RH Schumm, I Halow, SM Bailey, KL Churney, and RL Nuttall. 1982. The NBS Tables of Chemical Thermodynamic Properties. American Chemical Society and the American Institute of Physics, New York.

Watson JHP, IW Croudace, PAB James, JM Charnock, and D Ellwood. 2001. "Adsorption of Radioactive Metals by Strongly Magnetic Iron Sulfide Nanoparticles Produced by Sulfate-Reducing Bacteria." Separations Science and Technology 36:2571-2607.

Wharton MJ, B Atkins, JM Charnock, FR Livens, RAD Pattrick, and D Collison. 2000. "An X-Ray Absorption Specroscopy Study of the Coprecipitation of Tc and Re with Mackinawite (FeS)." Applied Geochemistry 15:347-354.

Wildung RE, ed. 1989. "The Behavior of Technetium in Terrestrial and Aquatic Environs: A Symposium.” Health Physics. 57(2):235-364

Wildung RE, TR Garland, KM McFadden, and CE Cowan. 1984. "Technetium Sorption in Surface Soils." In Technetium in the Environment., eds G Desmet and C Myttenarere. Elsevier, Essex, England.

Wildung RE, KM McFadden, and TR Garland. 1979. "Technetium Sources and Behavior in the Environment." Journal of Environmental Quality 8:156-161. 
Wildung RE, RC Routson, RJ Serne, and TR Garland. 1974. "Pertechnetate, Iodide and Methyl Iodide Retention by Surface Soils." Pacific Northwest National Laboratory Annual Report for 1974, BNWL1950, Pt. 2. Pacific Northwest Laboratory, Richland, Washington.

Wildung RE, YA Gorby, KM Krupka, NJ Hess, SW Li, AE Plymale, JP McKinley, and JK Fredrickson. 2000. "Effect of Electron Donor and Solution Chemistry on Products of Dissimilatory Reduction of Technetium by Shewanella putrefaciens." Applied and Environmental Microbiology 66:451-2460.

Wolfrumm C and K Bunzl. 1986. "Sorption and Desorption of Technetium by Humic Substances under Oxic and Anoxic Conditions." Journal of Radioanalytical and Nuclear Chemistry 99:315-323.

Xia Y, NJ Hess, and AR Felmy. 2006. "Stability Constants of Technetium(IV) Oxalate Complexes as a Function of Ionic Strength.” Radiochimica Acta 94:137-141.

Xiong Y and SA Wood. 1999. "Experimental Determination of the Solubility of $\mathrm{ReO}_{2}$ and the Dominant Oxidation State of Rhenium in Hydrothermal Solutions." Chemical Geology 158:245-256.

Yanagisawa K and Y Muramatsu. 1995. "Transfer of Technetium from Soil to Paddy and Upland Rice." Journal of Radiation Research 36:171-178.

Yanagisawa K, H Takeda, K Miyamoto, and S Fuma. 1999. Transfer of technetium from paddy soil to rice seedling. Journal of Radioanalytical and Nuclear Chemistry 243, 403-408.

Zachara JM., SM Heald, BH Jeon, RK Kukkadapu, CX Liu, JP McKinley, AC Dohnalkova, and DA Moore. 2007. "Reduction of Pertechnetate [Tc(VII)] by Aqueous Fe(II) and the Nature of Solid Phase Redox Products." Geochimica et Cosmochimica Acta 71:2137-2157.

Zhang, P-C, JL Krumhansl, and PV Brady. 2000. "Boehmite Sorbs Perrhenate and Pertechnetate." Radiochimica Acta 88:369-373. 


\section{Distribution}

No. of

Copies

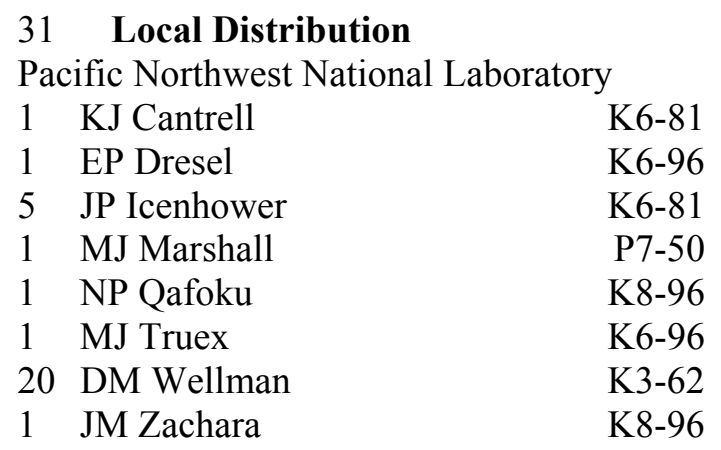

Distr.1 




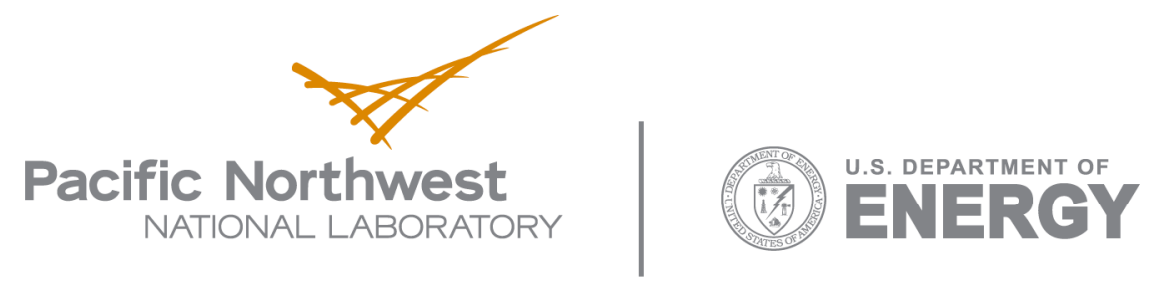

902 Battelle Boulevard

P.O. Box 999

Richland, WA 99352

1-888-375-PNNL (7665)

www.pnl.gov 